Prepared for the U.S. Department of Energy

under Contract DE-AC05-76RL01830

\title{
Waste Acceptance Testing of Secondary Waste Forms: Cast Stone, Ceramicrete and DuraLith
}

SV Mattigod MJ Lindberg

JH Westsik, Jr. KE Parker

CW Chung

August 2011

Pacific Northwest

NATIONAL LABORATORY

Proudly Operated by Battelle Since 1965 


\section{DISCLAIMER}

This report was prepared as an account of work sponsored by an agency of the United States Government. Neither the United States Government nor any agency thereof, nor Battelle Memorial Institute, nor any of their employees, makes any warranty, express or implied, or assumes any legal liability or responsibility for the accuracy, completeness, or usefulness of any information, apparatus, product, or process diselosed, or represents that its use would not infringe privately owned rights. Reference herein to any specific commercial product, process, or service by trade name, trademark, manufacturer, or otherwise does not necessarily constitute or imply its endorsement, recommendation, or favoring by the United States Government or any agency thereof, or Battelle Memorial Institute. The views and opinions of authors expressed herein do not necessarily state or reflect those of the United States Government or any agency thereof.

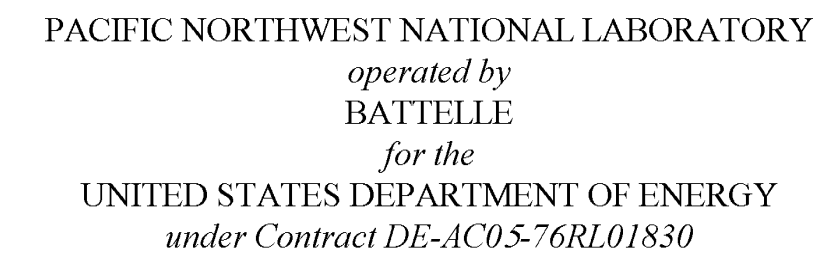

Printed in the United States of America

Available to DOE and DOE contractors from the Office of Scientific and Technical Information,

P.O. Box 62, Oak Ridge, TN 37831-0062;

ph: (865) 576-8401

fax: $(865) 576-5728$

email: reports(a) adonis.osti.gov

\footnotetext{
Available to the public from the National Technical Information Service, U.S. Department of Commerce, 5285 Port Royal Rd., Springfield, VA 22161 ph: (800) 553-6847 fax: $(703) 605-6900$ email: orders@ntis.fedworld.gov online ordering: http://www.ntis.gov/ordering.htm
} 


\title{
Waste Acceptance Testing of Secondary Waste Forms: Cast Stone, Ceramicrete and DuraLith
}

\author{
SV Mattigod \\ MJ Lindberg \\ JH Westsik, Jr. \\ KE Parker
}

CW Chung

August 2011

Prepared for

the U.S. Department of Energy

under Contract DE-AC05-76RL01830

Pacific Northwest National Laboratory

Richland, Washington 99352 



\section{Summary}

The Hanford Site in southeastern Washington State has 56 million gallons of radioactive and chemically hazardous wastes stored in 177 underground tanks (ORP 2010). The U.S. Department of Energy Office of River Protection, through its contractors, is constructing the Hanford Tank Waste Treatment and Immobilization Plant (WTP) to convert the radioactive and hazardous wastes into stable glass waste forms for disposal. Within the WTP, the pretreatment facility will receive the retrieved waste from the tank farms and separate it into two treated process streams. These waste streams will be vitrified, and the resulting waste canisters will be sent to offsite (high-level waste) and onsite (immobilized low-activity waste [ILAW]) repositories. As part of the pretreatment and ILAW processing, liquid secondary wastes will be generated that will be transferred to the Effluent Treatment Facility (ETF) on the Hanford Site for further treatment. These liquid secondary wastes will be converted to stable solid waste forms that will be disposed of in the Integrated Disposal Facility (IDF).

To support the selection of a waste form for the liquid secondary wastes from WTP, Washington River Protection Solutions has initiated secondary-waste-form testing work at Pacific Northwest National Laboratory (PNNL). In anticipation of a down-selection process for a waste form for the Solidification Treatment Unit to be added to the ETF, PNNL is conducting tests on four candidate waste forms to evaluate their ability to meet potential waste acceptance criteria for immobilized secondary wastes that would be placed in the IDF. Based on the technical literature and previous testing, the following four waste forms were selected for further testing and evaluation for stabilizing and solidifying WTP liquid secondary wastes:

- Cast Stone, a fly ash and blast-furnace slag-based waste form

- Ceramicrete phosphate-bonded ceramic

- DuraLith alkali-aluminosilicate geopolymer

- Fluidized Bed Steam Reformer (FBSR) granular product encapsulated within a geopolymer waste form.

Previous to the testing documented here, the Cast Stone, Ceramicrete, and DuraLith underwent a development and optimization testing program to prepare formulations specifically for the anticipated secondary waste to be treated in the ETF. The FBSR waste form is being developed through a separate project. In this study, the Cast Stone specimens were prepared with secondary waste simulants at 2-M, 4$\mathrm{M}$, and 6-M sodium. Ceramicrete was prepared with a 2-M sodium simulant and DuraLith was prepared with a 6-M sodium simulant. All were spiked with ${ }^{99} \mathrm{Tc}$ to measure technetium release rates. Those optimized formulations for Cast Stone, Ceramicrete, and DuraLith were tested to demonstrate their ability to meet waste form performance criteria including:

- Free liquids per EPA Method 9095, Paint Filter Liquids Test (EPA 2004)

- Land Disposal Requirements treatment standards per EPA Method 1311, Toxicity Characteristic Leaching Procedure (EPA 1999)

- Compressive strength per American Society for Testing of Materials (ASTM) Standard C39, Compressive Strength of Cylindrical Concrete Specimens (ASTM 2010). Compressive strengths to 
be measured before and after thermal cycling per ASTM Standard B553, Standard Test Method for

Thermocycling of Electroplated Plastics, (ASTM 1985) and after 90 days of water immersion.

- Leachability indices for the constituents of concern using:

- American National Standards Institute/American Nuclear Society (ANSI/ANS) Standard16.1, Measurement of the Leachability of Solidified Low-Level Radioactive Waste by a Short Term Test Procedure (ANSI/ANS 2003)

- ASTM C1308-08, Accelerated Leach Test for Diffusive Releases from Solidified Waste and a Computer Program to Model Diffusive, Fractional Leaching from Cylindrical Waste Forms (ASTM 2008)

- EPA draft method 1315, Mass Transfer Rates of Constituents in Monolith or Compacted Granular Materials Using a Semi-Dynamic Tank Leaching Test. (EPA 2009b)

None of the waste forms showed any residual free liquids in the laboratory-scale preparations; all three therefore met the free-liquids requirement.

All three waste forms met the Universal Treatment Standards in 40 CFR 268 to demonstrate that the waste forms would meet RCRA Land Disposal Restriction for hazardous wastes.

All three waste forms demonstrated compressive strengths above the minimum $3.45 \mathrm{MPa}$ (500 psi) set as a target for cement-based waste forms. Further, none of the waste forms showed any significant degradation in compressive strength after undergoing thermal cycling (30 cycles in a 10-day period) between $-40^{\circ} \mathrm{C}$ and $60^{\circ} \mathrm{C}$ or water immersion for 90 days.

The three leach test methods are intended to measure the diffusion rates of contaminants from the waste forms. Results are reported in terms of diffusion coefficients and a leachability index (LI) calculated based on the diffusion coefficients. A smaller diffusion coefficient and a larger LI are desired. The NRC, in its Waste Form Technical Position (NRC 1991), provides recommendations and guidance regarding methods to demonstrate waste stability for land disposal of radioactive waste. Included is a recommendation to conduct leach tests using the ANS 16.1 method. The resulting leachability index (LI) should be greater than 6.0. For Hanford secondary wastes, the LI $>6.0$ criterion applies to sodium leached from the waste form. For technetium and iodine, higher targets of LI > 9 for Tc and LI > 11 for iodine have been set based on early waste-disposal risk and performance assessment analyses. The results of these three leach tests conducted for a total time between 11days (ASTM C1308) and 90 days (ANS 16.1) showed:

- Technetium diffusivity: ANSI/ANS 16.1, ASTM C1308, and EPA 1315 tests indicated that all the waste forms had leachability indices better than the target LI $>9$ for technetium.

- Rhenium diffusivity: Cast Stone 2M specimens, when tested using EPA 1315 protocol, had leachability indices better than the target LI $>9$ for technetium based on rhenium as a surrogate for technetium. All other waste forms tested by ANSI/ANS 16.1, ASTM C1308, and EPA 1315 test methods had leachability indices that were below the target LI $>9$ for Tc based on rhenium release. These studies indicated that use of $\mathrm{Re}(\mathrm{VII})$ as a surrogate for ${ }^{99} \mathrm{Tc}(\mathrm{VII})$ in low temperature secondary waste forms containing reductants will provide overestimated diffusivity values for ${ }^{99} \mathrm{Tc}$. Therefore, it is not appropriate to use Re as a surrogate ${ }^{99} \mathrm{Tc}$ in future low temperature waste form studies. 
- Iodine diffusivity: ANSI/ANS 16.1, ASTM C1308, and EPA 1315 tests indicated that the three waste forms had leachability indices that were below the target LI $>11$ for iodine. Therefore, it may be necessary to use a more effective sequestering material than the silver zeolite used in two of the waste forms (Ceramicrete and DuraLith)

- Sodium diffusivity: All the waste form specimens tested by the three leach methods (ANSI/ANS 16.1, ASTM C1308, and EPA 1315) exceeded the target LI value of 6.

- All three leach methods (ANS 16.1, ASTM C1308 and EPA 1315) provided similar ${ }^{99}$ Tc diffusivity values for both short-time transient diffusivity effects as well as long-term ( $\leq 90$ days) steady diffusivity from each of the three tested waste forms (Cast Stone 2M, Ceramicrete and DuraLith). Therefore, any one of the three methods can be used to determine the contaminant diffusivities from a selected waste form. 



\section{Acknowledgments}

The authors are grateful to Kimball Smith and Max Melvin at Washington River Protection Solutions, LLC, Richland, WA, for the project funding and programmatic guidance. We thank Mark Bowden and Bruce Arey of Environmental and Molecular Sciences Laboratory for generating X-ray diffraction and Scanning Electron Microscope-Energy Dispersive Spectroscopy data, respectively. We also thank Jeff Serne for providing a thorough and perceptive review of the report. We would like to acknowledge Maura Zimmerschied for editing and Megan Peters for formatting this report. Pacific Northwest National Laboratory is a multi-program national laboratory operated by Battelle for the U.S. Department of Energy under Contract DE-AC05-76RL01830. 



\section{Acronyms and Abbreviations}

\begin{tabular}{|c|c|}
\hline ANS & American Nuclear Society \\
\hline ANSI & American National Standards Institute \\
\hline ASTM & American Society for Testing and Materials \\
\hline BFS & blast furnace slag \\
\hline DIW & deionized water \\
\hline DOE & U.S. Department of Energy \\
\hline Ecology & Washington State Department of Ecology \\
\hline ED & energy dispersive \\
\hline EPA & U.S. Environmental Protection Agency \\
\hline ETF & Effluent Treatment Facility \\
\hline FBSR & Fluidized Bed Steam Reformer \\
\hline HLW & high-level waste \\
\hline IDF & Integrated Disposal Facility \\
\hline ILAW & immobilized LAW \\
\hline LAW & low-activity waste \\
\hline LDR & Land Disposal Restrictions \\
\hline LI & leachability index \\
\hline LOI & Loss on Ignition \\
\hline NRC & U.S. Nuclear Regulatory Commission \\
\hline ORP & Office of River Protection \\
\hline PNNL & Pacific Northwest National Laboratory \\
\hline RCRA & Resource Conservation and Recovery Act \\
\hline SBS & submerged-bed scrubber \\
\hline SEM & scanning electron microscopy \\
\hline SRNL & Savannah River National Laboratory \\
\hline STU & Solidification Treatment Unit \\
\hline SW & solid waste \\
\hline TCLP & Toxicity Characteristic Leaching Procedure \\
\hline TDS & total dissolved solids \\
\hline TOC & total organic carbon \\
\hline TSS & total suspended solids \\
\hline UTS & universal treatment standards \\
\hline WAC & waste acceptance criteria \\
\hline WESP & wet-electrostatic precipitator \\
\hline WRPS & Washington River Protection Solutions \\
\hline WTP & Hanford Tank Waste Treatment and Immobilization Plant \\
\hline XRD & $\mathrm{X}$-ray diffraction \\
\hline
\end{tabular}





\section{Contents}

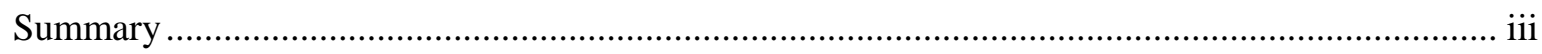

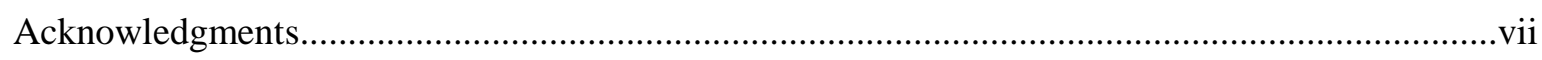

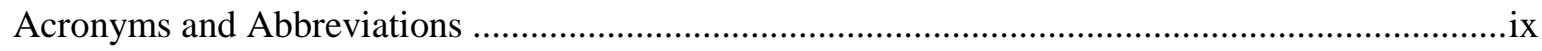

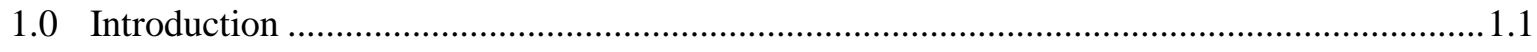

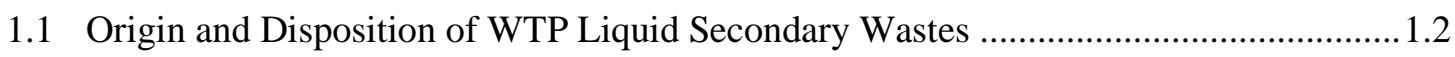

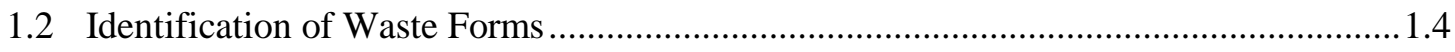

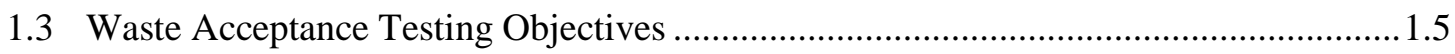

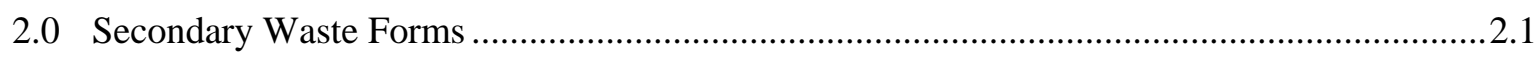

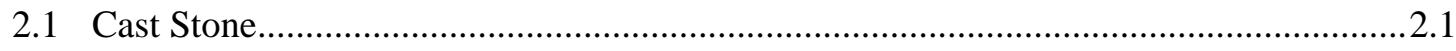

2.2 Ceramicrete Phosphate-Bonded Ceramic .................................................................. 2.1

2.3 DuraLith Alkali Aluminosilicate Geopolymer..........................................................2.2

3.0 Secondary Waste Simulant and Waste Form Preparation .................................................... 3.1

3.1 Secondary Waste Simulant..................................................................................... 3.1

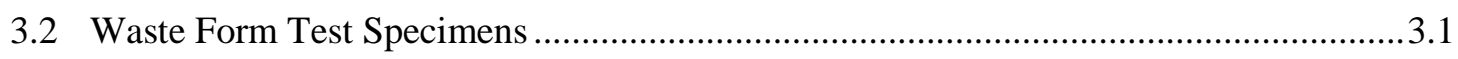

3.2.1 Cast Stone Preparation ................................................................................ 3.3

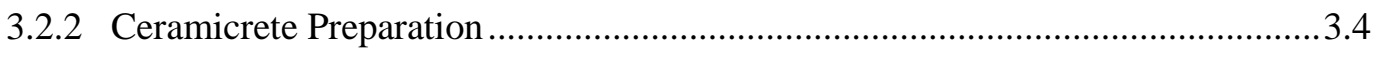

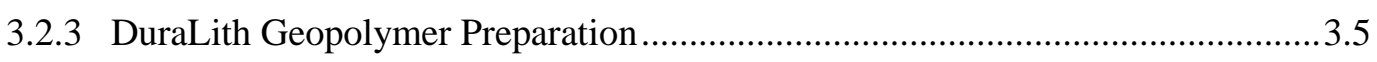

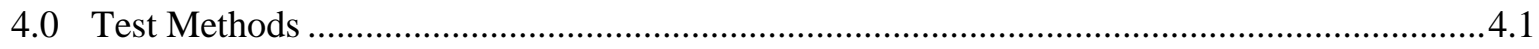

4.1 Waste Form Characterization ................................................................................ 4.1

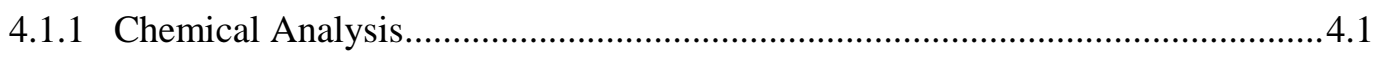

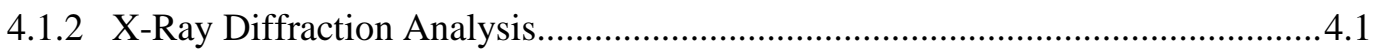

4.1.3 Scanning Electron Microscopy and Energy-Dispersive Spectroscopy ................4.2

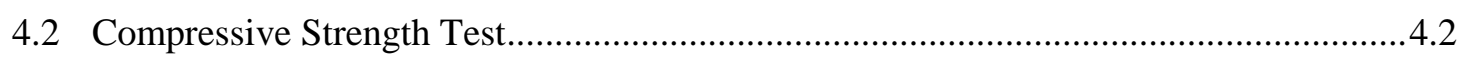

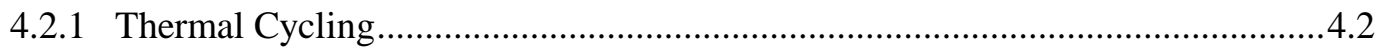

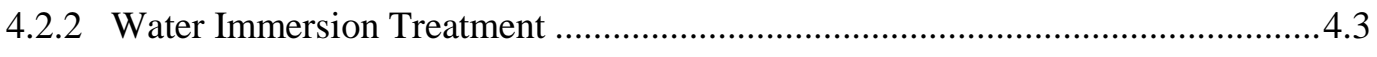

4.2.3 Ambient-Air Storage of Test Specimens........................................................ 4.3

4.2.4 Compressive Strength Test.......................................................................... 4.3

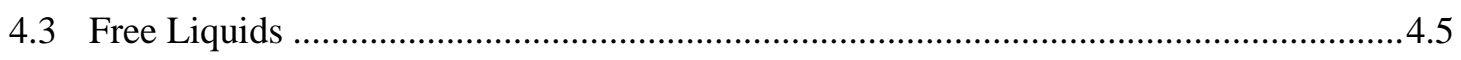

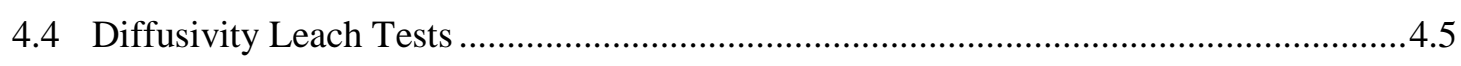

4.4.1 ANSI/ANS 16.1 Leach Test ....................................................................... 4.6

4.4.2 ASTM C1308-08 Leach Test ....................................................................... 4.7

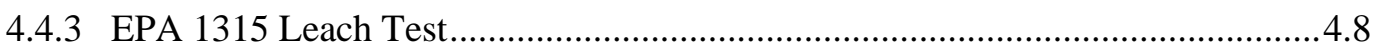

4.4.4 EPA 1313 Leach Test................................................................................ 4.10

4.4.5 EPA 1316 Leach Test................................................................................10

4.5 Toxicity Characteristic Leaching Procedure (EPA 1311) ........................................... 4.11

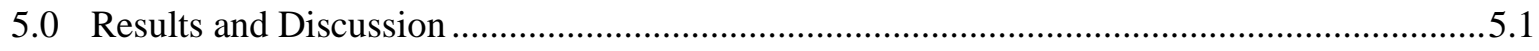




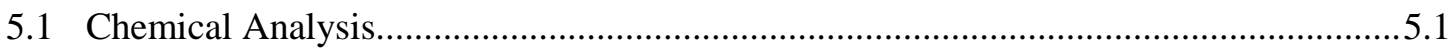

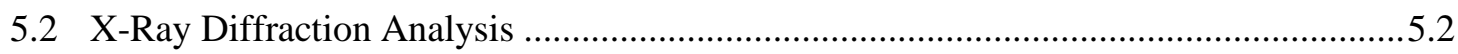

5.3 Scanning Electron Microscopy and Energy-Dispersive Spectroscopy ..........................5.6

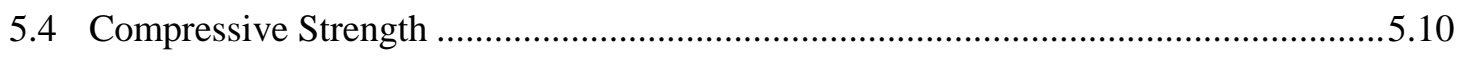

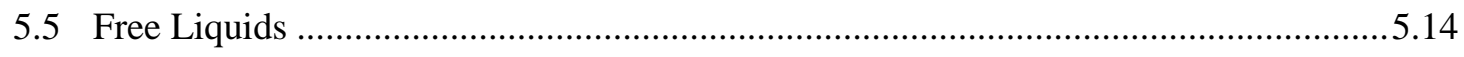

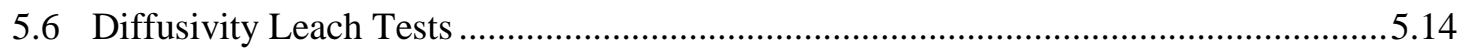

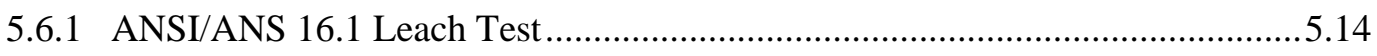

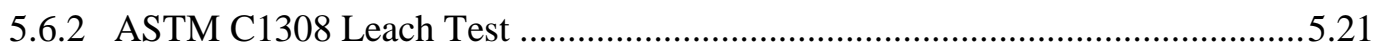

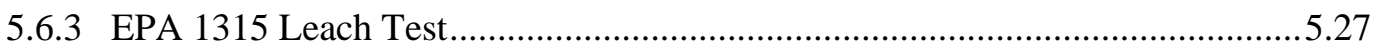

5.6.4 Suitability of Rhenium as a Technetium Surrogate in Secondary Waste Form

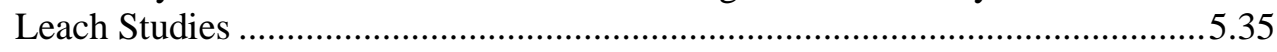

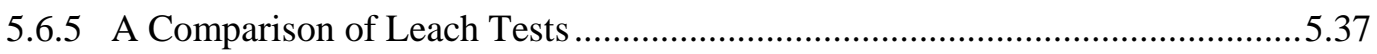

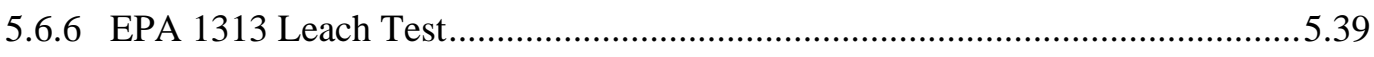

5.6.7 EPA 1316 Leach Test....................................................................................

5.6.8 Toxicity Characteristic Leaching Procedure (EPA 1311) ...................................5.44

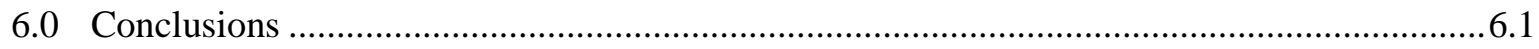

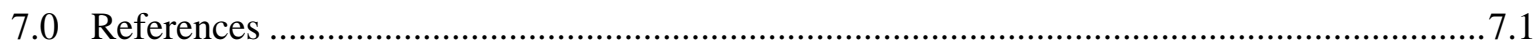




\section{Figures}

1.1 Schematic of Secondary Waste Sources ........................................................................ 1.3

4.1 The Environmental Chamber Used for Thermal Cycling of Secondary Waste Forms ............... 4.3

4.2 The Compressive Strength Test Apparatus .......................................................................... 4.4

4.3 EPA 1315 Testing Scheme (Source: EPA 2009b) ............................................................. 4.9

5.1 Phase Identification for Cast Stone Sample CS-11-S1-2-601 .............................................. 5.4

5.2 Phase Identification for Cast Stone Sample CS-11-S1-4-401 ............................................... 5.4

5.3 Phase Identification for Cast Stone Sample CS-11-S1-6-504 ................................................ 5.5

5.4 Phase Identification for Ceramicrete Sample CE-11-S1-2-10X ........................................... 5.5

5.5 Phase Identification for DuraLith Sample GP-11-S1-6-310 .............................................. 5.6

5.6 SEM Image Elemental Maps and ED Spectrum of Cast Stone .............................................. 5.7

5.7 SEM Image, Elemental Maps and ED Spectrum of Ceramicrete Sample .............................. 5.8

5.8 SEM Image, Elemental Maps, and ED Spectrum of DuraLith Sample .................................. 5.9

5.9 Compressive Strengths of Secondary Waste Forms after Various Treatments ........................ 5.10

5.10 Preexisting Crack Observed in Ceramicrete Specimen ....................................................... 5.11

5.11 Fracture Patterns of Cast Stone, Ceramicrete, and DuraLith ................................................. 5.11

5.12 Patterns of Surface Cracks Observed after Thermal Cycling................................................. 5.12

5.13 Surface Crack Patterns of DuraLith Specimen................................................................... 5.13

5.14 Compressive Strength of Cast Stone Specimens According to the Na Concentration Levels .... 5.13

5.15 Technetium Diffusivity of Cast Stone, Ceramicrete and DuraLith Monoliths ........................ 5.15

5.16 Rhenium Diffusivity of Cast Stone, Ceramicrete and DuraLith Monoliths ............................ 5.16

5.17 Iodine Diffusivity of Cast Stone, Ceramicrete and DuraLith Monoliths ................................. 5.17

5.18 Sodium Diffusivity of Cast Stone, Ceramicrete and DuraLith Monoliths .............................. 5.18

5.19 Technetium Diffusivity of Cast Stone, Ceramicrete and DuraLith Monoliths ........................ 5.21

5.20 Rhenium Diffusivity of Cast Stone, Ceramicrete and DuraLith Monoliths .............................. 5.22

5.21 Iodine Diffusivity of Cast Stone, Ceramicrete and DuraLith Monoliths ................................. 5.23

5.22 Sodium Diffusivity of Cast Stone, Ceramicrete and DuraLith Monoliths ............................... 5.24

5.23 Technetium Diffusivity of Cast Stone, Ceramicrete and DuraLith Monoliths ........................ 5.27

5.24 Rhenium Diffusivity of Cast Stone, Ceramicrete and DuraLith Monoliths ............................ 5.28

5.25 Iodine Diffusivity of Cast Stone, Ceramicrete and DuraLith Monoliths ................................ 5.29

5.26 Sodium Diffusivity of Cast Stone, Ceramicrete and DuraLith Monoliths ............................... 5.30

5.27 A Comparison of ${ }^{99} \mathrm{Tc}$ and Re Diffusivities for Cast Stone 2M............................................ 5.35

5.28 A Comparison of ${ }^{99} \mathrm{Tc}$ and Re Diffusivities for Ceramicrete ................................................ 5.35

5.29 A Comparison of ${ }^{99} \mathrm{Tc}$ and Re Diffusivities for DuraLith..................................................... 5.36

5.30 A Comparison of ${ }^{99} \mathrm{Tc}$ Diffusivity Values for Cast Stone Calculated From Data From Three Different Leach Methods

5.31 A Comparison of ${ }^{99} \mathrm{Tc}$ Diffusivity Values for Ceramicrete Calculated from Data from Three Different Leach Methods 
5.32 A Comparison of ${ }^{99} \mathrm{Tc}$ Diffusivity Values for DuraLith Calculated from Data from Three Different Leach Methods

5.33 Sodium Concentrations in EPA 1313 Method Leachates from Ceramicrete ............................. 5.40

5.34 Silica Concentrations in EPA 1313 Method Leachates from Ceramicrete ............................... 5.40

5.35 Rhenium Concentrations in EPA 1313 Method Leachates from Ceramicrete.......................... 5.41

5.36 Technetium Concentrations in EPA 1313 Method Leachates from Ceramicrete .................... 5.4

5.37 EPA 1316 Method Ceramicrete Leachate $\mathrm{pH}$ Values ............................................................ 5.42

5.38 Sodium Concentrations in EPA 1316 Method Leachates from Ceramicrete ............................. 5.43

5.39 Rhenium Concentrations in EPA 1316 Method Leachates from Ceramicrete .......................... 5.43

5.40 Technetium Concentrations in EPA 1316 Method Leachates from Ceramicrete ..................... 5.44 


\section{Tables}

Table 3.1. Waste Acceptance Testing Waste Form Test Matrix.................................................... 3.1

Table 3.2. Waste Acceptance Test Simulant Composition ............................................................... 3.2

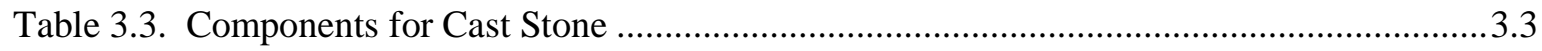

Table 3.4. Ingredients for Ceramicrete Waste Form .................................................................. 3.4

Table 3.5. Ceramicrete Formulation—List of Ingredients and Suggested Sources .......................... 3.4

Table 3.6. Ingredients for DuraLith Geopolymer .......................................................................... 3.5

Table 3.7. DuraLith Formulation — List of Ingredients, Functions and Suggested Sources ............3.6

Table 4.1. Comparison of Diffusivity Leach Test Methods.........................................................4.6

Table 4.2. Universal Treatment Standards from 40 CFR Part 268 ............................................11

Table 5.1. Chemical Composition of Cast Stone, Ceramicrete and DuraLith Waste Forms ..........5.1

Table 5.2. Relative Quantities of Phases Identified in Cast Stone, Ceramicrete and DuraLith

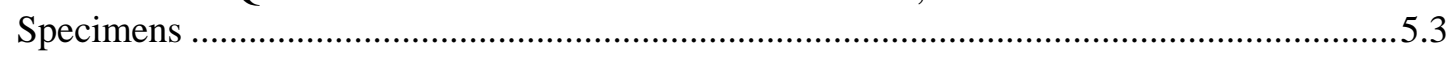

Table 5.3. ANS 16.1 Leach Test - Technetium Diffusivity and Leaching Indices of Cast Stone,

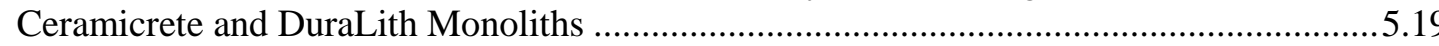

Table 5.4. ANS 16.1 Leach Test - Rhenium Diffusivity and Leaching Indices of Cast Stone,

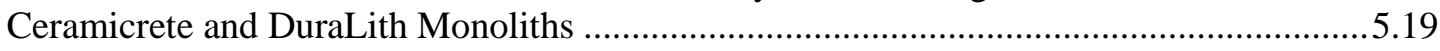

Table 5.5. ANS 16.1 Leach Test - Iodine Diffusivity and Leaching Indices of Cast Stone, Ceramicrete and DuraLith Monoliths ............................................................................5.20

Table 5.6. ANS 16.1 Leach Test - Sodium Diffusivity and Leaching Indices of Cast Stone,

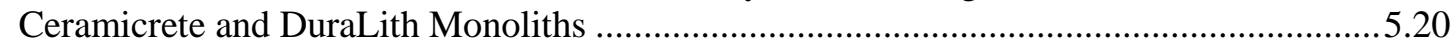

Table 5.7. ASTM C1308 Leach Test - Technetium Diffusivity and Leaching Indices of Cast

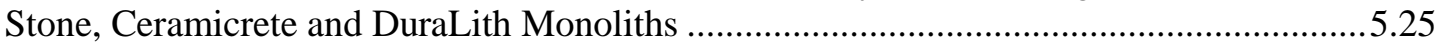

Table 5.8. ASTM C1308 Leach Test - Rhenium Diffusivity and Leaching Indices of Cast Stone, Ceramicrete and DuraLith Monoliths 5.25

Table 5.9. ASTM C1308 Leach Test - Iodine Diffusivity and Leaching Indices of Cast Stone, Ceramicrete and DuraLith Monoliths . .5 .26$

Table 5.10. ASTM C1308 Leach Test - Sodium Diffusivity and Leaching Indices of Cast Stone, Ceramicrete and DuraLith Monoliths 5.26

Table 5.11. EPA 1315 Leach Test - Technetium Diffusivity and Leaching Indices of Cast Stone, Ceramicrete and DuraLith Monoliths

Table 5.12. EPA 1315 Leach Test - Rhenium Diffusivity and Leaching Indices of Cast Stone, Ceramicrete and DuraLith Monoliths 5.32

Table 5.13. EPA1315 Leach Test - Iodine Diffusivity and Leaching Indices of Cast Stone, Ceramicrete and DuraLith Monoliths

Table 5.14. EPA 1315 Leach Test - Sodium Diffusivity and Leaching Indices of Cast Stone, Ceramicrete and DuraLith Monoliths 5.34

Table 5.15. Leachate Concentrations of Selected Elements and pH from EPA 1313 Test ..........5.39

Table 5.16. Leachate Concentrations of Selected Elements from EPA 1316 Test ......................5.42

Table 5.17. TCLP Test Results for Cast Stone, Ceramicrete and DuraLith Waste Forms ...........5.45 


\subsection{Introduction}

At the Hanford Site in southeastern Washington State, 56 million gallons of radioactive and chemically hazardous wastes are stored in 177 underground tanks (ORP 2010). The U.S. Department of Energy (DOE), Office of River Protection (ORP), through its contractors, is constructing the Hanford Tank Waste Treatment and Immobilization Plant (WTP) to convert the radioactive and hazardous wastes into stable glass waste forms for disposal. Within the WTP, the pretreatment facility will receive the waste retrieved from the tank farms and separate it into two treated process streams, high-level waste (HLW) and low-activity waste (LAW). The HLW mixture will be sent to the HLW Vitrification Facility, and the pretreated LAW stream will be sent to the LAW Vitrification Facility. The two WTP vitrification facilities will convert these process streams into glass, which will be poured directly into stainless steel canisters. The canisters of immobilized HLW (IHLW) will ultimately be disposed of at an offsite federal repository. The canisters of immobilized LAW (ILAW) will be disposed of onsite in the Integrated Disposal Facility (IDF). As part of the pretreatment and ILAW processing, liquid secondary wastes will be generated that will be transferred to the Effluent Treatment Facility (ETF) on the Hanford Site for further treatment. These liquid secondary wastes will be converted to stable solid waste forms that will be disposed of in the IDF. Liquid effluents from the ETF will be discharged through the State-Approved Land Disposal Site.

The ETF is an existing operating facility on the Hanford site. It is a Resource Conservation and Recovery Act (RCRA)-permitted, multi-waste treatment and storage unit that can accept Washington State regulated dangerous, low-level, and mixed wastewaters for treatment. The ETF receives, treats, and disposes of liquid effluents from cleanup projects on the Hanford Site. The ETF handles treated effluent under the ETF State Wastewater Discharge Permit and solidified liquid effluents under the Washington State Department of Ecology (Ecology) Dangerous Waste Permit. The ETF lacks the capacity to treat the liquid process effluents from the WTP once the WTP begins operating.

Milestone M-047-00 of the Hanford Federal Facility Agreement and Consent Order (Ecology et al., 1989) requires that DOE "complete all work necessary to provide facilities for management of secondary liquid waste from the WTP" by "the date that the WTP achieves initial plant operations." Interim milestones are to be negotiated by June 30, 2012. DOE is considering a non-major system acquisition project for a Secondary Liquid Waste Treatment Project to add the needed capacity to the ETF (DOE 2011). Among the alternatives to be evaluated for providing the needed capacity for handling the WTP liquid secondary wastes are

- Upgrade ETF, plus construct a Solidification Treatment Unit

- Upgrade ETF, with new ion-exchange facilities, plus construct a Solidification Treatment Unit

- Upgrade ETF, plus recycle evaporator concentrates back to tank farms by truck or pipeline

- Provide additional evaporative capacity, plus use Fluidized Bed Steam Reformer technology.

Washington River Protection Solutions (WRPS), a prime contractor to DOE, is responsible for the ETF upgrades needed to receive secondary liquid wastes from the WTP at Hanford. In planning for the Secondary Liquid Waste Treatment Project, WRPS anticipates two down-selections. The first downselection will evaluate the four alternatives as well as options for providing the necessary capacity for treating the secondary liquid wastes from WTP and other Hanford Site liquid-waste generators. Then, 
should the preferred alternative include adding a Solidification Treatment Unit, a second down-selection would evaluate alternative waste forms for solidifying treated wastes from the ETF.

To support the selection of a waste form for the liquid secondary wastes from WTP, WRPS has initiated secondary waste form testing work at Pacific Northwest National Laboratory (PNNL). In 2009, preliminary screening of waste forms was conducted to assess the viability of alternative waste forms for solidifying the liquid secondary wastes (Pierce et al., 2010a, 2010b). A testing program was initiated to further develop, optimize, and characterize the Cast Stone, Ceramicrete, and DuraLith waste forms to stabilize/solidify the anticipated liquid secondary wastes. Testing was also conducted on a previously prepared Fluidized Bed Steam Reformer (FBSR) waste form to develop a suite of comparable test results such that the performance of all four candidate waste forms could be evaluated.

\subsection{Origin and Disposition of WTP Liquid Secondary Wastes}

The WTP includes three major treatment facilities, including a pretreatment building, an HLW vitrification building, and an LAW vitrification building. Liquid wastes, sludges, and salt cake retrieved from the underground storage tanks will be piped to the pretreatment building. There, the wastes will be separated into a low-volume HLW stream containing most of the actinides, cesium, and strontium and a large-volume LAW stream with most of the sodium and aluminum. From an environmental protection perspective, the largest fractions of the inventory in the tanks of technetium-99 $\left({ }^{99} \mathrm{Tc}\right)$ and iodine-129 $\left({ }^{129} \mathrm{I}\right)$, both long-lived radionuclides, are expected to reside in the LAW stream. The HLW stream will be transferred to the HLW vitrification building where it will be combined with glass-forming chemicals and melted in a high-temperature melter, and the resulting molten glass will be poured into stainless steel canisters to cool and be stored until it can be shipped to a federal repository. Similarly, the LAW stream will be piped to the LAW vitrification building where it will be melted with glass formers in a hightemperature melter and poured into steel canisters for disposal in IDF.

Secondary liquid wastes will be generated in the pretreatment and vitrification buildings. Figure 1.1 shows a schematic of the sources of the secondary wastes. In the pretreatment building, a front-end evaporator will be used to concentrate liquid wastes received from the underground storage tanks and liquid process effluents from the HLW vitrification building. A back-end evaporator will be used to concentrate the LAW from the pretreatment process plus condensates from the LAW melter primary offgas treatment stream. Condensates from the front-end and back-end evaporators will be collected in process condensate collection tanks.

Both the HLW and LAW vitrification facilities include off-gas treatment systems to treat the gaseous effluents from their respective glass melters. These effluents include water vapor, chemicals that are volatile at the elevated melter temperatures, and particulates. In each vitrification process, the melter offgas passes through primary off-gas treatment systems that include submerged-bed scrubbers (SBSs) and wet-electrostatic precipitators (WESPs). Condensates from the HLW SBSs and WESPs are recycled to the pretreatment front-end evaporator. Condensates from the LAW SBSs and WESPs are recycled to the pretreatment back-end evaporator. In addition, the LAW vitrification system includes a secondary off-gas treatment system that includes a final caustic scrubber. A small fraction of the total ${ }^{99} \mathrm{Tc}$ and ${ }^{129} \mathrm{I}$ inventory to the LAW vitrification facility is expected to be captured in the caustic scrubber solution; that caustic scrubber solution is recycled back to the condensate collection tanks. Collectively, the pretreatment evaporator condensates and the LAW melter off-gas caustic scrubber solution form the secondary waste stream that is transferred from WTP to ETF for disposition. 


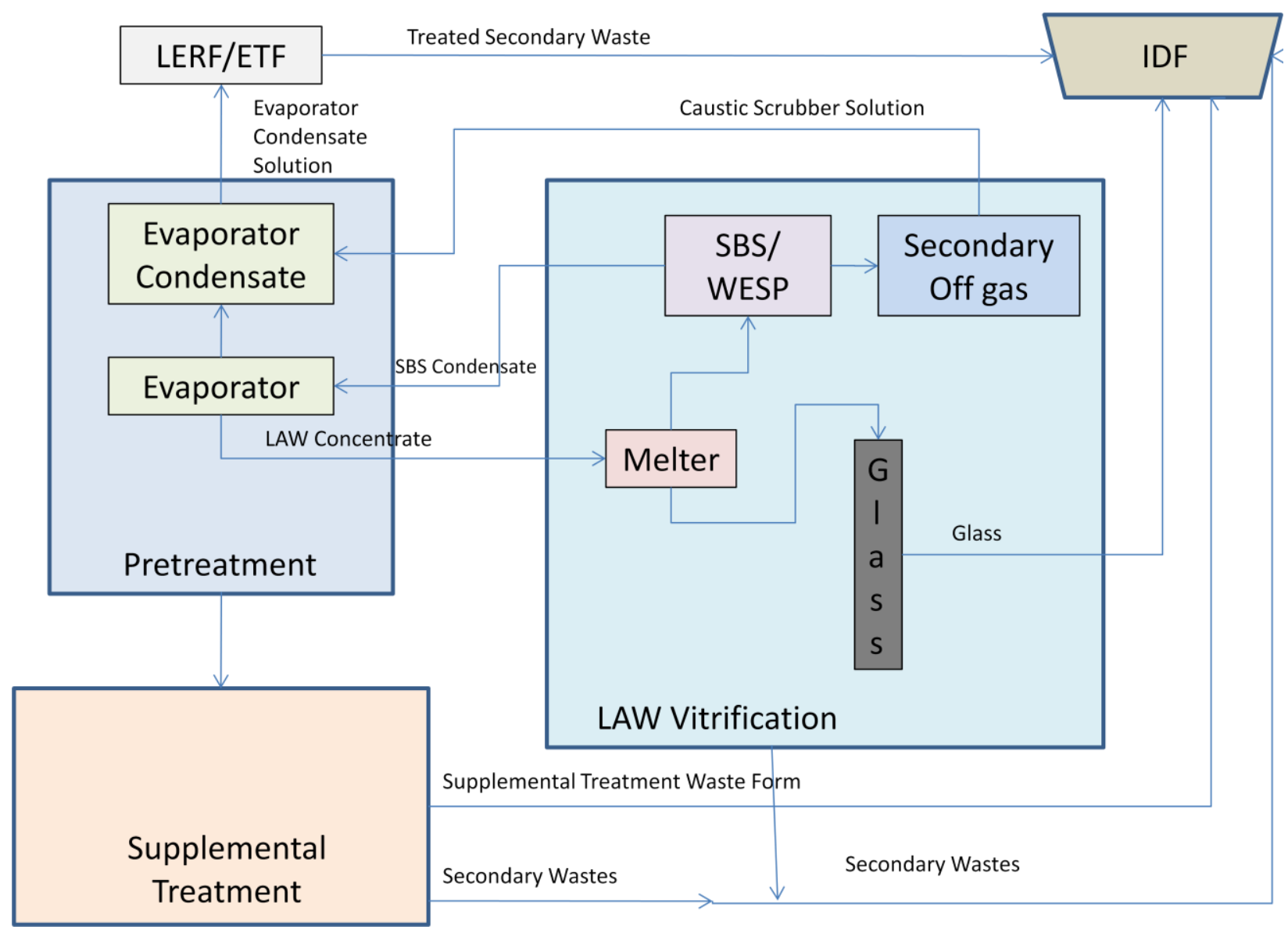

Figure 1.1. Schematic of Secondary Waste Sources. (LERF = Liquid Effluent Retention Facility; $\mathrm{SBS}=$ submerged bed scrubber; WESP $=$ wet electrostatic precipitator)

The LAW melter off-gas SBS and WESP condensates are recycled back to the pretreatment facility and ultimately back to the LAW melter. Under some operational scenarios, some or all of the condensate from the LAW melter off-gas SBS and WESP would go directly to a secondary waste stream exiting the WTP. For example, in an "early LAW" scenario, the LAW melter would begin operations using selected tank wastes before the pretreatment facility came on line. In this case, the SBS and WESP condensates would be combined with the caustic scrubber solution as a single liquid secondary waste stream from the WTP. In another scenario, a fraction of the SBS/WESP condensate would be bled from the recycle stream that is sent back to the pretreatment facility so that the buildup of constituents in the LAW melter feed that would reduce the waste loading in the LAW glass would be minimized. In some recent secondary waste form testing, a 10\% fraction of the SBS/WESP condensate was assumed to be bled off and combined with caustic scrubber solution in the secondary waste stream to ETF.

Currently defined secondary waste streams originate from the WTP and do not consider alternative supplemental treatment technologies. A second LAW melter facility would operate under the same assumptions as the first LAW melter facility. In the Baseline Case, approximately $626 \mathrm{Mgal}$ of radioactive dangerous liquid effluent (consisting of secondary waste from the WTP, the second LAW facility, the 242-A Evaporator, an aluminum removal facility, and a supplemental TRU treatment system) is projected to be treated by the ETF over the duration of the treatment mission (ORP 2010). 
Washington River Protection Solutions is considering the design and construction of a Solidification Treatment Unit (STU) for the ETF at Hanford. The ETF is an RCRA-permitted multi-waste treatment and storage unit and can accept dangerous, low-level, and mixed wastewaters for treatment. The STU needs to be operational by 2018 to receive secondary liquid wastes generated during operation of the WTP. Addition of the STU to ETF will provide the additional capacity needed for ETF to process the increased volume of secondary wastes expected to be produced by WTP.

\subsection{Identification of Waste Forms}

Numerous waste forms have been evaluated for stabilizing and solidifying radioactive and hazardous wastes. Radioactive HLWs from nuclear fuel reprocessing are converted to a glass waste form in stainless steel canisters for disposal at a federal repository. Liquid low-level wastes and mixed radioactive/hazardous wastes are typically stabilized and solidified before disposal in near-surface facilities. Spence and Shi (2005) provide a review of inorganic and organic binders that have been used for waste stabilization. Several recent studies have evaluated technologies specifically for solidifying WTP liquid secondary wastes. In 2006, PNNL completed an evaluation of three low-temperature waste forms, including an alkali-aluminosilicate hydroceramic cement, DuraLith ${ }^{\circledR}$ alkali-aluminosilicate geopolymer, and Ceramicrete phosphate-bonded ceramic (Russell et al., 2006). Alternatives to vitrification and Portland cement-based grouts were identified through an unrestricted request for proposals. Relatively mature, low-temperature $\left(<150^{\circ} \mathrm{C}\right)$ processes with the feasibility of deployment within 1 to 2 years were favored by the evaluation criteria. That study demonstrated the potential of DuraLith alkali-aluminosilicate geopolymer and Ceramicrete phosphate bonded ceramic as adequate waste forms for the secondary wastes. As part of the Advanced Remediation Technologies program, THOR $^{\circledR}$ Treatment Technologies LLC and Savannah River National Laboratory (SRNL) demonstrated the feasibility of a Fluidized Bed Steam Reformer granular product encapsulated in a geopolymer matrix using an early LAW secondary waste stream composed of LAW off-gas treatment condensates that would normally be recycled within the WTP plant (THOR 2009).

The first activity for the Secondary Waste Form Testing project at PNNL was to conduct a literature survey to identify and evaluate candidate waste forms for solidifying the secondary wastes (Pierce et al., 2010a). In addition to the baseline, Cast Stone, Portland cement-based waste form and the DuraLith, Ceramicrete, and FBSR waste forms, several less mature technologies, including several aluminosilicates and an iron-oxide mineral called goethite with the capacity to specifically retain technetium, were identified. In parallel, WRPS issued a call for expressions of interest for secondary-waste immobilization technologies. Responses to that call included a glass waste form produced with the Geomelt ${ }^{\circledR}$ Vitrification Technology, a waste form based on the synroc ceramic titanate mineral, and a Nochar, Inc., waste form prepared from a blend of acrylics and acrylamide copolymers (Pierce et al., 2010a).

Based on the technical literature and previous testing, the following four waste forms were selected for further testing and evaluation for stabilizing and solidifying WTP liquid secondary wastes:

- Cast Stone, a fly ash and blast-furnace slag-based waste form

- Ceramicrete phosphate-bonded ceramic

- DuraLith alkali-aluminosilicate geopolymer

- FBSR granular product encapsulated within a geopolymer waste form. 
Additional testing was performed in 2010 to further develop and optimize Cast Stone, DuraLith, and Ceramicrete for the projected liquid secondary waste compositions. The objectives of this additional testing were to start the process of optimizing the quantities of binder materials to improve waste loading and evaluate the robustness of the waste form to waste-stream variability. The results of this optimization work have been documented in reports by Sundaram et al. (2011), Singh et al. (2011), and Gong et al. (2011) for Cast Stone, Ceramicrete, and DuraLith, respectively. Testing is also being conducted on an FBSR waste form.

The purpose of the work documented in this report is to test the preliminarily optimized Cast Stone, Ceramicrete, and DuraLith secondary waste formulations to demonstrate whether these waste forms will meet requirements for disposal in the IDF.

\subsection{Waste Acceptance Testing Objectives}

Wastes intended for disposal in IDF must meet requirements of DOE Order 435.1 (DOE 1999) and permit requirements established by Ecology. The IDF permit does not identify specific waste acceptance criteria (WAC) for solidified secondary wastes. It does require that "Six months prior to IDF operations, Permittees shall submit to Ecology for review, approval, and incorporation into the permit, all WAC to address at a minimum, the following: physical/chemical criteria, liquids and liquid containing waste, land disposal restriction treatment standards and prohibitions, compatibility of waste with liner, gas generation, packaging, handling of packages, minimization of subsidence."

IDF WACs have not been established for wastes to be disposed of in the facility. Several draft WACs have been proposed, some limited to the ILAW glass waste form and a bulk vitrification waste form. Others have included criteria applicable to other waste forms as well (RPP 2005). Included are criteria with respect to free liquids, compliance with land disposal restrictions, compressive strength, and leachability. For the purposes of the secondary waste form down-selection, the following requirements apply:

- Land Disposal Restrictions: The waste form will meet the land disposal requirements in 40 CFR Part 268 by meeting the universal treatment standards (UTS) in 40 CFR 268.48 via the Toxicity Characteristic Leaching Procedure (TCLP) test.

- Free Liquids: The waste form shall contain no detectable free liquids as defined in SW-846 Method 9095 (EPA 2004).

- Leachability Index: The waste form shall have a sodium leachability index (LI) greater than 6.0 when tested in deionized water using the American National Standards Institute/American Nuclear Society (ANSI/ANS)-16.1 method (ANSI/ANS 2003) or Environmental Protection Agency (EPA) Method 1315 (EPA 2009b). The waste form shall have a rhenium or technetium LI greater than 9.0 and LI exceeding 11.0 for ${ }^{129}$ I. These requirements are based on the Nuclear Regulatory Commission's (NRC's) Technical Position on Waste Form (NRC 1991) and on early waste disposal risk assessments and performance assessment (PA) analyses. The stated values need to be validated and verified based on more recent IDF performance assessments.

- Compressive Strength: The compressive strength of the waste form shall be at least $3.54 \mathrm{MPa}$ (500 psi) when tested in accordance with ASTM C39/C39M (ASTM 2010). This is based on the 
NRC's Technical Position on Waste Form (NRC 1991), which is more restrictive for cement-based waste forms.

To confirm that the waste forms will meet the WAC, each waste form will be subjected to the following tests:

- Free liquids per EPA Method 9095, Paint Filter Liquids Test (EPA 2004)

- Land Disposal Requirements (LDR) treatment standards per EPA Method 1311, Toxicity Characteristic Leaching Procedure (EPA 1999)

- Compressive strength per American Society for Testing of Materials (ASTM) Standard C39, "Compressive Strength of Cylindrical Concrete Specimens (ASTM 2010). Compressive strengths will be measured before and after thermal cycling per ASTM Standard B553, Standard Test Method for Thermocycling of Electroplated Plastics, " (ASTM 1985) and after 90 days of water immersion testing per the methods in the next bullet. (Note: ASTM B553 is referenced in the NRC Technical Position on Waste Form but has been withdrawn by ASTM.).

- Leachability indices for the constituents of concern using:

- American National Standards Institute/American Nuclear Society (ANSI/ANS) Standard16.1, Measurement of the Leachability of Solidified Low-Level Radioactive Waste by a Short Term Test Procedure (ANSI/ANS 2003)

- ASTM C1308-08, Accelerated Leach Test for Diffusive Releases from Solidified Waste and a Computer Program to Model Diffusive, Fractional Leaching from Cylindrical Waste Forms (ASTM 2008)

- EPA draft method 1315, Mass Transfer Rates of Constituents in Monolith or Compacted Granular Materials Using a Semi-Dynamic Tank Leaching Test. (EPA 2009b)

The NRC Waste Form Technical Position (NRC 1991) provides additional guidance on implementing these procedures for low-level waste forms. DuraLith, Ceramicrete, and Cast Stone waste forms have previously demonstrated their compressive strength after irradiation (Russell et al., 2006). Therefore, the radiation stability was not reconfirmed as part of the testing described in this report. Also, because the waste forms do not contain any carbonaceous materials that would support biological growth, biodegradation testing was not conducted on these waste forms.

The Cast Stone, Ceramicrete, and DuraLith waste form materials that were tested were prepared based on the available waste form optimization work conducted for these waste forms and the baseline secondary waste simulant developed from the WTP G2 flowsheet model and used in the development and optimization work. The Ceramicrete was also tested using the EPA 1313 and 1316 test methods to provide screening data comparable to data for Cast Stone and DuraLith obtained during Phase 1 testing. The Cast Stone waste form was prepared with the secondary waste simulant at concentrations of 2-M, 4$\mathrm{M}$, and 6-M sodium to fill data gaps from the initial Cast Stone development and optimization work reported by Sundaram et al. (2011). 


\subsection{Secondary Waste Forms}

Cast Stone, DuraLith alkali-aluminosilicate geopolymer, and Ceramicrete phosphate-bonded ceramic were evaluated via the waste acceptance tests as described in the test plan (Mattigod et al., 2011). Each waste form is described briefly below.

\subsection{Cast Stone}

Cast Stone (also called "Containerized Cast Stone" [CCS]) is a waste form that is essentially a mixture of Class F fly ash, Grade 100 or 120 blast furnace slag (BFS), and Type I and II Portland cement. CH2M Hill Hanford Group Inc. developed this waste form to solidify numerous waste streams, including secondary waste generated at the Hanford Site. The Cast Stone waste form is the current baseline technology for solidifying the liquid secondary wastes from WTP. Pierce et al., (2010b) demonstrated that the Cast Stone is a viable waste form for immobilization of the WTP secondary wastes. Sundaram et al. (2011) conducted additional work to develop and start the optimization of Cast Stone for the secondary liquid wastes to be treated at ETF. Their work evaluated the performance of the Cast Stone formulation over a range of waste simulant compositions and concentrations and confirmed the viability of the Cast Stone as a waste form for the secondary wastes.

\subsection{Ceramicrete Phosphate-Bonded Ceramic}

Ceramicrete phosphate-bonded ceramic was developed as part of the U. S. Department of Energy (DOE) Environmental Management (EM) program to stabilize and contain radioactive waste constituents such as technetium (Tc), Strontium (Sr), and Cesium (Cs). This technology has been demonstrated on various waste streams (liquids, fly ashes, debris) and has shown to adequately retain both radioactive (U, Tc, $\mathrm{Pu})$ and hazardous contaminants $(\mathrm{Hg}, \mathrm{Pb}, \mathrm{Cr}$, etc.).

Ceramicrete is fabricated by acid/base reaction of calcined magnesium oxide and monopotassium phosphate which, when mixed with water, form a slurry that sets into a hard ceramic in a few hours. According to the developers (Wagh et al., 1997, 1999) of this waste form:

- The process is simple and quite similar to the Portland cement process.

- Equipment needed is the same as that used for cementitious waste form.

- Ceramicrete has a strong, dense matrix, and has a superior ability to bind contaminants, making it an excellent candidate for macro encapsulation.

The chemical reaction for Ceramicrete formation can be represented as (Wagh et al. 1997, 1999):

$$
\mathrm{MgO}+\mathrm{KH}_{2} \mathrm{PO}_{4}+5 \mathrm{H}_{2} \mathrm{O}--------\rightarrow \mathrm{MgKPO}_{4} \cdot 6 \mathrm{H}_{2} \mathrm{O}
$$

The developers claim that the resulting $\mathrm{MgKPO}_{4} \cdot 6 \mathrm{H}_{2} \mathrm{O}$ phase is extremely stable and has a solubility product of $2 \times 10^{-11}$. Typically there is no residual water associated with the hardened product; it is bound as water of hydration. Ceramicrete has the unusual property of binding to itself. Because of the flexibility of this process, various materials may be added to promote higher strength, resistance to fracturing, and to reduce porosity. One can add as much as $80 \mathrm{wt} \%$ of fly ash in the Ceramicrete dry 
powder mix; there is no specific requirement for the particle size of the fly ash. Wagh (1999) found that, during the reaction, in addition to the phosphate bonding, silicophosphate bonding may also occur that provides enhanced structural properties.

\subsection{DuraLith Alkali Aluminosilicate Geopolymer}

The DuraLith waste form is based on generic geopolymer chemistry as described in a previous report (Gong et al., 2006). The DuraLith composition can be adjusted and optimized for specific requirements of radioactive waste stabilization, specific ingredients that are employed, and specific additives that are used to enhance the immobilization of heavy metals and radionuclides such as ${ }^{99} \mathrm{Tc}$ and ${ }^{129} \mathrm{I}$. The results of screening tests conducted previously are documented in a report by Pierce et al. (2010b).

The waste stream (in this case, an aqueous solution) is tailored by adding sodium- and/or potassium hydroxide together with a rapidly dissolving form of silica, e.g., fumed silica. The resulting solution is referred to as the "activator." The activator is one of three components needed to make a DuraLith waste form. The second component is the "composite binder." This is a mixture of reactive, low-CaO aluminosilicate (e.g., metakaolin $\mathrm{Al}_{2} \mathrm{O}_{3} \cdot 2 \mathrm{SiO}_{2}$, fly ash Class $\mathrm{F}$ ) and high-CaO aluminosilicate (e.g., blast furnace slag, fly ash Class $\mathrm{C}$ ). The third component, the "enhancer," is composed of a group of additives that are used to enhance the fixation of heavy metals and key radionuclides such as ${ }^{99} \mathrm{Tc}$ and ${ }^{129} \mathrm{I}$. Enhancers are usually added to the waste solution before preparing the final activator solution. The preparation of a DuraLith waste form involves simple mixing of the binder with the activator, which can be done in the final waste form container but would preferably be done in a mixing vessel prior to transferring the slurry into the final waste form container. 


\subsection{Secondary Waste Simulant and Waste Form Preparation}

\subsection{Secondary Waste Simulant}

The simulant used in the waste acceptance testing has the baseline composition defined by Josephson et al. (2010). The composition was derived from G2 flowsheet model predictions of the effluent from the WTP LAW melter off-gas caustic scrubber. The baseline composition represents the medians of the component values, normalized to 1-M sodium, over the duration of the WTP Hanford tank waste mission. The RCRA metals, ${ }^{99} \mathrm{Tc}, \mathrm{Re}$ (as a surrogate for Tc), and iodine are based on the maximum predicted concentrations over that WTP mission duration. Table 3.1 shows the baseline simulant composition, and the mass of chemicals used to generate stimulants with 2-M, 4-M and 6-M Na concentrations. The actual simulant composition will be in the range of 4- to 6-M Na depending on the optimized formulation for each waste form. Technetium $\left({ }^{99} \mathrm{Tc}\right)$ was added to the simulant for those samples prepared for leach testing.

\subsection{Waste Form Test Specimens}

Sufficient numbers of test specimens of each waste form were prepared to complete the test matrix shown in Table 3.1. The simulant S1 with 2-, 4- and 6-M Na molarities were used in specimen preparation (Table 3.2). The non-radioactive (non-rad) specimens were 2-inch-diameter by 4-inch-high cylinders necessary for the compressive strength testing. All specimens were observed for the presence of free liquids during curing.

Table 3.1. Waste Acceptance Testing Waste Form Test Matrix

\begin{tabular}{llccc}
\hline \multicolumn{1}{c}{ Specimen Conditions } & \multicolumn{1}{c}{ Test Method } & Cast Stone & Ceramicrete & DuraLith \\
\hline Compressive Strength - Non Rad Samples & ASTM C39 (28-day cure) & $\bullet$ & $\bullet$ & $\bullet$ \\
\hline As Prepared & ASTM B553, C39 & $\bullet$ & $\bullet$ & $\bullet$ \\
Thermal Cycling & ANSI/ANS 16.1, ASTM C39 & $\bullet$ & $\bullet$ & $\bullet$ \\
After Immersion & ASTM C39 (90-day cure) & $\bullet$ & $\bullet$ & $\bullet$ \\
As Prepared ${ }^{(\text {a) }}$ & & & & $\bullet$ \\
\hline Free Liquids - Non Rad Samples & Visual Observation & $\bullet$ & & $\bullet$ \\
\hline As Prepared & & & $\bullet$ & $\bullet$ \\
\hline TCLP- Non Rad Samples & EPA 1311 & & & $\bullet$ \\
\hline As Prepared & & $\bullet$ & $\bullet$ \\
\hline Tc Diffusivity - Tc-Spiked samples & ANSI/ANS 16.1 & $\bullet$ & $\bullet$ \\
\hline As Prepared & ASTM C1308 & $\bullet$ & $\bullet$ \\
As Prepared & EPA 1315 & $\bullet$ & $\bullet$ \\
As Prepared & Chemical analysis & & & $\bullet$ \\
As Prepared & EPA 1313 & (b) & $\bullet$ \\
\hline Leaching Characteristics - Tc Spiked Samples & & $\bullet$ \\
\hline pH 4, 6, 8, 10, 12 & EPA 1316 & & $\bullet$ \\
L/S ratio 10, $5,2 \mathrm{~mL} / \mathrm{g}$ & (b)
\end{tabular}

(a) conducted in parallel with immersion samples

(b) EPA 1313 and 1316 tests were previously conducted on Cast Stone and DuraLith Samples (Pierce et al., 2010b) 
Table 3.2. Waste Acceptance Test Simulant Composition

\begin{tabular}{|c|c|c|c|c|c|c|c|}
\hline Element & $\begin{array}{l}\text { Baseline }^{(\mathrm{a})} \\
\text { (Moles/L) }\end{array}$ & Chemical Formula & CAS $\#^{(b)}$ & $\begin{array}{l}\text { Formula } \\
\mathrm{Wt}(\mathrm{g})\end{array}$ & $\begin{array}{c}\text { Chemical Mass } \\
(\mathrm{g} / \mathrm{L})\end{array}$ & $\begin{array}{c}\text { Chemical Mass } \\
(\mathrm{g} / \mathrm{L})\end{array}$ & $\begin{array}{c}\text { Chemical Mass } \\
(\mathrm{g} / \mathrm{L})\end{array}$ \\
\hline Na molarity & 1.00 & -- & -- & -- & 2.00 & 4.00 & 6.00 \\
\hline $\mathrm{Ag}$ & $6.27 \mathrm{E}-06$ & $\mathrm{AgNO}_{3}$ & $7761-88-8$ & 169.87 & 0.002 & 0.004 & 0.006 \\
\hline $\mathrm{Al}$ & 9.39E-02 & gibbsite & $21645-51-2$ & 78.00 & 14.648 & 29.297 & 43.945 \\
\hline As & $3.48 \mathrm{E}-05$ & $\mathrm{Na}_{2} \mathrm{HAsO}_{4} \cdot 7 \mathrm{H}_{2} \mathrm{O}$ & $10048-95-0$ & 312.01 & 0.022 & 0.043 & 0.065 \\
\hline $\mathrm{Cd}$ & $1.57 \mathrm{E}-06$ & $\mathrm{Cd}\left(\mathrm{NO}_{3}\right)_{2} \cdot 4 \mathrm{H}_{2} \mathrm{O}$ & $10022-68-1$ & 308.48 & 0.001 & 0.002 & 0.003 \\
\hline $\mathrm{Cl}-$ & $2.25 \mathrm{E}-02$ & $\mathrm{NaCl}$ & $7647-14-5$ & 58.44 & 2.630 & 5.260 & 7.889 \\
\hline $\mathrm{CO}_{3}^{-2}$ & $2.28 \mathrm{E}-02$ & $\mathrm{Na}_{2} \mathrm{CO}_{3}$ & $497-19-8$ & 105.99 & 4.833 & 9.666 & 14.499 \\
\hline $\mathrm{Cr}$ & 2.03E-04 & $\mathrm{Na}_{2} \mathrm{Cr}_{2} \mathrm{O}_{7} \cdot 2 \mathrm{H}_{2} \mathrm{O}$ & $7789-12-0$ & 298.00 & 0.121 & 0.121 & 0.363 \\
\hline $\mathrm{F}$ & $5.57 \mathrm{E}-04$ & $\mathrm{NaF}$ & $7681-49-4$ & 41.99 & 0.047 & 0.094 & 0.140 \\
\hline $\mathrm{Hg}$ & $1.13 \mathrm{E}-05$ & $\mathrm{Hg}\left(\mathrm{NO}_{3}\right)_{2} \cdot \mathrm{H}_{2} \mathrm{O}$ & $7783-34-8$ & 342.62 & 0.008 & 0.015 & 0.023 \\
\hline I & $4.62 \mathrm{E}-06$ & $\mathrm{NaI}$ & $7681-82-5$ & 149.89 & 0.001 & 0.003 & 0.004 \\
\hline K & $5.82 \mathrm{E}-04$ & $\mathrm{KNO}_{3}$ & 7757-79-1 & 101.10 & 0.118 & 0.235 & 0.353 \\
\hline $\mathrm{NO}_{3}^{-}$ & $3.28 \mathrm{E}-01$ & $\mathrm{NaNO}_{3}$ & $7631-99-4$ & 84.99 & 55.753 & 111.507 & 167.260 \\
\hline $\mathrm{NO}_{2}^{-}$ & $1.20 \mathrm{E}-02$ & $\mathrm{NaNO}_{2}$ & $7632-00-0$ & 69.00 & 1.656 & 3.312 & 4.968 \\
\hline $\mathrm{OH}$ & $3.98 \mathrm{E}-01$ & $\mathrm{NaOH}$ & $1310-73-2$ & 40.00 & 31.840 & 63.680 & 95.520 \\
\hline $\mathrm{Pb}$ & 8.99E-06 & $\mathrm{Pb}\left(\mathrm{NO}_{3}\right)_{2}$ & $10099-74-8$ & 331.23 & 0.006 & 0.012 & 0.018 \\
\hline $\mathrm{PO}_{4}{ }^{3-}$ & $6.87 \mathrm{E}-03$ & $\mathrm{Na}_{3} \mathrm{PO}_{4} \cdot 12 \mathrm{H}_{2} \mathrm{O}$ & $7558-80-7$ & 380.13 & 5.223 & 10.446 & 15.669 \\
\hline $\operatorname{Re}$ & $1.81 \mathrm{E}-05$ & $\mathrm{NaReO}_{4}$ & $13472-33-8$ & 273.19 & 0.010 & 0.02 & 0.030 \\
\hline $\mathrm{Si}$ & $1.88 \mathrm{E}-03$ & $\mathrm{Na}_{2} \mathrm{SiO}_{3} \cdot 9 \mathrm{H}_{2} \mathrm{O}$ & $13517-24-3$ & 284.20 & 1.069 & 2.137 & 3.206 \\
\hline $\mathrm{SO}_{4}{ }^{2-}$ & $4.41 \mathrm{E}-03$ & $\mathrm{Na}_{2} \mathrm{SO}_{4}$ & $7757-82-6$ & 142.04 & 1.253 & 2.506 & 3.758 \\
\hline${ }^{99} \mathrm{Tc}$ & $3.05 \mathrm{E}-05^{(\mathrm{c})}$ & ${ }^{99} \mathrm{Tc}$ & -- & 99.00 & $0.0001^{\mathrm{c}}$ & $0.0002^{c}$ & $0.0003^{c}$ \\
\hline $\mathrm{TOC}^{(\mathrm{d})}$ & 7.98E-02 & $\mathrm{Na}_{2} \mathrm{C}_{2} \mathrm{O}_{4}$ & $62-76-0$ & 134.00 & 21.386 & 42.773 & 64.159 \\
\hline $\mathrm{TOC}^{(\mathrm{d})}$ & $1.41 \mathrm{E}-02$ & $\mathrm{C}_{2} \mathrm{O}_{4} \cdot 2 \mathrm{H}_{2} \mathrm{O}$ & $6153-56-6$ & 126.07 & 3.555 & 7.110 & 10.666 \\
\hline \multicolumn{8}{|c|}{$\begin{array}{l}\text { (b) Chemical Abstracts Service Registry Number } \\
\text { (c) } \mathrm{Ci} / \mathrm{L} \\
\text { (d) As Oxalate }\end{array}$} \\
\hline
\end{tabular}




\subsubsection{Cast Stone Preparation}

The dry-materials blend for the Cast Stone was composed of cement, fly ash and grade-100 BFS. Samples were prepared using simulant concentrations of 2-M, 4-M and 6-M Na. To prepare the Cast Stone specimens, the simulant and dry materials were prepared separately and then combined. The mass percentages of the optimized Cast Stone dry ingredients (Sundaram et al. 2010) that were mixed with the three concentrations of sodium simulant are listed in Table 3.3.

Table 3.3. Components for Cast Stone

\begin{tabular}{lccc}
\hline \multicolumn{1}{c}{ Ingredients } & 2-M Na & 4-M Na & 6-M Na \\
& Wt (\%) & Wt (\%) & Wt (\%) \\
\hline Portland Cement, Type I, II & 5.7 & 5.4 & 5.0 \\
Fly Ash, Class F & 32.2 & 30.3 & 28.1 \\
Blast Furnace Slag, Grade 100 / 120 & 33.7 & 31.6 & 29.4 \\
Simulant (TDS+TSS) & 3.4 & 7.8 & 13.5 \\
Simulant (water component) & 25.1 & 24.9 & 24.0 \\
\hline (a) The sum of TDS (total dissolved solids) and TSS (total suspended solids) constitutes the solid \\
\multicolumn{4}{l}{} \\
\hline
\end{tabular}

The ratio of S1 2-M simulant solution to dry blend materials was 0.397:1. However, this simulant-todry-blend ratio was not applicable to the 4-M and 6-M Cast Stone due to the loss of workability from higher ionic-strength and higher undissolved-solid contents in the simulant. In order to have proper water content to enable proper workability, the actual water-to-solid ratio was calculated based on the S1 2-M simulant-to-dry-blend ratio $(0.335)$ by calculating total solid content (dry blend materials + dissolved and undissolved chemicals in the simulant) and the amount of deionized water (DIW) used for the preparation of simulant. The water-to-solid ratio of the Cast Stone 2-M mixture was used for designing formulation of 4-M- and 6-M-Na Cast Stone specimens.

Cast Stone specimens were prepared using a commercial KitchenAid ${ }^{\circledR}$ paddle mixer. First, simulant of the appropriate target concentration was poured into the mixer's bowl, and next the dry materials, namely cement, Class-F fly ash and blast furnace slag, were added. After adding the dry blend mixture, the mixer was turned on and rotated at the lowest speed level for 30 seconds. The mixer was stopped for 30-60 seconds in order to scrape down any paste adhering to the side and the bottom of the mixing bowl. Mixing resumed at medium speed for 90 seconds. The mixing time at medium speed was extended from the 60 seconds specified in ASTM C 305 to 90 seconds to provide better mixing of Cast Stone ingredients.

When mixing of the secondary-waste form was completed, the paste was poured into the 2-inch-by-4inch plastic cylindrical molds. Half of each cylindrical mold was filled with the paste and the paste was rodded 25 times using a stainless steel bar, and the paste was vibrated about 30 seconds to remove entrapped air voids in the specimens. Finally, more paste was poured into the partially filled cylindrical molds until the full height was reached, rodded for 25 times, and also vibrated about 30 seconds to remove air voids. After final casting, the molds were capped and sealed in plastic bags to prevent any loss of moisture. The specimen-filled molds were stored in the sealed plastic bags for seven days.

After seven days, all the specimens were taken out of the plastic bag and demolded. The demolded Cast Stone specimens were stored in a 100\% relative humidity closed container for 28 days. 


\subsubsection{Ceramicrete Preparation}

The Ceramicrete composition optimized for 2-M Na secondary waste (Singh 2011) is listed in Table 3.4 and the sources of ingredients are listed in Table 3.5. A commercial KitchenAid paddle mixer was used to mix the ingredients. First, the mixer was first turned on at the lowest speed, and the S1 2-M simulant was poured into the bowl followed by DIW. Tin chloride $\left(\mathrm{SnCl}_{2}\right)$ was then added and mixed for 4 minutes at the lowest speed to provide good dissolution of the $\mathrm{SnCl}_{2}$. After 4 minutes, silver zeolite was added and mixed for 3 minutes. Then dry materials, namely, magnesium oxide $(\mathrm{MgO})$, monopotassium phosphate $\left(\mathrm{KH}_{2} \mathrm{PO}_{4}\right)$, and Class-C fly ash were added in sequence and mixed for 10 minutes at the lowest speed. Actual mixing time recommended was 20 minutes, but due to the early setting of Ceramicrete, the mixing time was reduced to 10 minutes. All the mixing was done at the lowest speed level because the Ceramicrete mix was very fluid. After mixing, the Ceramicrete paste was poured into plastic molds. The molds were half-filled, rodded 25 times and then vibrated until a significant decrease in the release of bubbles was observed. The molds were then filled the rest of the way and were rodded 25 times and vibrated until no bubbles were observed on the surface. The molds were covered with a perforated plastic cap and cured for more than 2 weeks at room temperature.

Table 3.4. Ingredients for Ceramicrete Waste Form

\begin{tabular}{|c|c|}
\hline Ingredients & Weight $(\%)$ \\
\hline $\mathrm{MgO}$ & 9.6 \\
\hline $\mathrm{KH}_{2} \mathrm{PO}_{4}$ & 32.6 \\
\hline Fly Ash Class C & 34.5 \\
\hline Simulant $(\mathrm{TDS}+\mathrm{TSS})^{(\mathrm{a})}$ & 2.3 \\
\hline Water in Simulant & 17.0 \\
\hline Deionized water & 1.8 \\
\hline $\mathrm{SnCl}_{2}$ & 1.2 \\
\hline Silver Zeolite & 1.0 \\
\hline
\end{tabular}

(a) The sum of TDS and TSS constitutes the solid waste loading component of the secondary waste simulant.

Table 3.5. Ceramicrete Formulation-List of Ingredients and Suggested Sources

\begin{tabular}{ll}
\hline \multicolumn{1}{c}{ Ingredient } & \multicolumn{1}{c}{ Suggested Sources } \\
\hline Principal Ingredients & \\
\hline $\begin{array}{l}\text { Magnesium oxide (MgO P98) } \\
\text { Monopotassium phosphate (MKP-771) }\end{array}$ & $\begin{array}{l}\text { Martin Marietta Magnesia Specialties, MD } \\
\text { Bindan Corp., Oakbrook, IL } \\
\text { ICL Performance Products, Saint Louis, MO }\end{array}$ \\
Powder Fillers & \\
Class C Fly Ash & Lafarge, Chicago, IL \\
Calcium silicate (Wollastonite) & NYCO, Willsboro, NY \\
Blast furnace slag & Lafarge, Chicago, IL \\
\hline Additives & \\
\hline Boric acid, technical grade, $\mathrm{H}_{3} \mathrm{BO}_{3}$ & Fisher Scientific \\
Tin chloride, SnCl ${ }_{2}, 98 \%$ Reagent grade & Sigma-Aldrich \\
$\begin{array}{l}\text { Ag-loaded zeolite (Ionex Type Ag 400) } \\
\text { Potassium sulfide (I-5130) }\end{array}$ & $\begin{array}{l}\text { Molecular Products Inc., Boulder, CO } \\
\text { ChemService, Inc. }\end{array}$ \\
\hline
\end{tabular}




\subsubsection{DuraLith Geopolymer Preparation}

The components for the optimized DuraLith Formulation are listed in Table 3.6 (Gong et al., 2011). The components for preparing the specimens listed in Table 3.7 were obtained from commercial sources recommended by Gong et al. (2011). According to the optimized recipe, all solid-ingredient particle sizes should be less than 200 mesh.

The DuraLith specimens were prepared in two steps. The activator solution for DuraLith specimens was prepared in a Nalgene ${ }^{\circledR}$ beaker. Simulant (S1 6-M Na) was first poured into the Nalgene beaker and the solution was continuously stirred using a Cole-Parmer ${ }^{\circledR}$ constant speed rotating mixer. Next, tin fluoride $\left(\mathrm{SnF}_{2}\right)$ was added to the activator solution and to promote complete dissolution the mixture was stirred for 2 hours. Next, potassium hydroxide and sodium hydroxide were added slowly with continued stirring and making sure that the temperature of the mixture remained below $60{ }^{\circ} \mathrm{C}$. Finally silica fume was added to the activator solution and the activator mixture was stirred continuously for 24 hours. The stirred activator solution was thin with little or no solid deposit at the bottom or the corner of the beaker. The final mass of activator solution was determined, and if the loss in mass exceeded $0.2 \%$, sufficient water was added to bring it back to the original weight.

Table 3.6. Ingredients for DuraLith Geopolymer

\begin{tabular}{lc}
\hline \multicolumn{1}{c}{ Ingredient } & Weight (\%) \\
\hline Activator Solution & \\
\hline Simulant (TDS+TSS) ${ }^{(\mathrm{a})}$ & 8.6 \\
Water in simulant & 15.3 \\
$\mathrm{KOH}(99.9 \%)$ & 5.3 \\
$\mathrm{NaOH}(99 \%)$ & 0.7 \\
Silica Fume & 7.2 \\
$\mathrm{SnF}_{2}$ (97.5\%) & 1.0 \\
\hline Dry Blend Materials & \\
\hline Meta-kaolin & 11.1 \\
Ground Blast Furnace Slag & 28.8 \\
Ground Copper Slag & 2.0 \\
Fine River Sand (3.5\% water) & 19.0 \\
IONEX Ag 900 silver zeolite & 1.0 \\
\hline (a) The sum of TDS and TSS constitutes the solid \\
\multicolumn{2}{c}{ waste loading component of the secondary waste } \\
$\quad$ simulant.
\end{tabular}


Table 3.7. DuraLith Formulation-List of Ingredients, Functions and Suggested Sources

\begin{tabular}{lcc}
\hline \multicolumn{1}{c}{ Ingredient } & Function & Suggested Sources \\
\hline Main Ingredients & & \\
\hline Ground blast furnace slag & Reactive binder & Lafarge North America \\
Fine river sand & Filler material & Local sources \\
Metakaolin & Reactive binder & Thiele Kaolin Company \\
Fumed silica & Waste Activator & Norchem Corporation \\
Potassium hydroxide $(\mathrm{KOH})$ & Activating Alkali & NOAH Technologies Corp. \\
\hline Additives & & \\
\hline Ground copper slag & I sequestor & Opta Minerals, Inc. \\
Sodium hydroxide $(\mathrm{NaOH})$ & Activating Alkali & NOAH Technologies Corp. \\
IONEX Ag 900 & I sequestor & Molecular Products Inc. \\
Zeolite Type $5 \mathrm{~A}$ & Nucleator & -- \\
Tin Fluoride $\left(\mathrm{SnF}_{2}\right)$ & Tc Reductant & Alfa Aesar \\
\hline
\end{tabular}

In the second step, the activator solution was poured into the bowl of a KitchenAid paddle mixture that contained a homogeneous blend of dry ingredients consisting of meta-kaolinite, blast furnace slag, copper slag, sand, and silver zeolite. Due to the highly viscous characteristic of initial DuraLith paste, the mixing was conducted for 3 minutes at intermediate speeds until a homogeneous paste was obtained. Mixing was continued until a pourable blend was obtained. Total mixing time did not exceed 10 minutes to prevent excessive rise in temperature. The well-mixed DuraLith paste was then poured into plastic molds. The entire process was completed in about 30 minutes. The molds were partially filled and then vibrated until a significant decrease in the release of bubbles was observed. The mold was then filled the rest of the way and was vibrated until no bubbles were observed on the surface. The molds were then covered with a perforated plastic cap for 24 hours at room temperature, after which the monoliths were removed from the molds and allowed to air dry for 24 hours. Finally, the monoliths were placed into sealed plastic bags and cured for an additional 28 days at room temperature, for a total cure time of 30 days. The mixer was cleaned immediately, before the residual DuraLith mix in the container and on the mixing blades began to solidify. 


\subsection{Test Methods}

\subsection{Waste Form Characterization}

Chemical analyses were conducted on waste specimens that contained ${ }^{99} \mathrm{Tc}$-spikes. X-ray diffraction (XRD) analysis and scanning electron microscopy (SEM) with energy dispersive spectrometry analysis was performed on samples of each waste form to determine the sample mineralogy and to gain insight into the distribution of elements within the waste form.

\subsubsection{Chemical Analysis}

Specimens of Cast Stone, Ceramicrete, and DuraLith product were chemically analyzed by digesting the samples in a microwave oven using a strong-acid medium ${ }^{1}$. The resulting digestates were analyzed by inductively coupled plasma optical emission spectrometry and inductively coupled plasma mass spectrometry.

\subsubsection{X-Ray Diffraction Analysis}

XRD data were collected with a PANalytical X'Pert Bragg-Brentano diffractometer using $\mathrm{Cu} \mathrm{K} \alpha$ radiation $(\lambda=1.5418 \AA)$, a graphite post-diffraction monochromator, and variable-divergence and antiscatter slits (illuminated length $=10 \mathrm{~mm}$ ). The waste form specimens were ground and loaded into traditional well-type aluminum holders with a cavity measuring $20 \times 15 \times 2 \mathrm{~mm}$. Initial survey scans were collected between 5 and $75^{\circ} 2 \theta$, counting for $1 \mathrm{~s}$ at $0.04^{\circ}$ steps.

The crystalline phases present were identified using the search/match capabilities of the JADE software (v 9.3, Materials Data Inc., California). Reference patterns from the International Committee for Diffraction Data (ICDD) database were visually compared to the experimental traces. Further candidate phases based on the expected chemistry were also compared in an effort to identify compounds that were not found by the automatic search procedure.

To estimate the quantity of amorphous material, a weighed amount of corundum $\left(\alpha-\mathrm{Al}_{2} \mathrm{O}_{3}\right.$, approximately $10 \mathrm{wt} \%$ ) was mixed and homogenized into each sample using a mortar and pestle, and additional diffraction patterns were collected by scanning each of the mixed corundum-spiked waste form samples between 2 and $100^{\circ} 2 \theta$ with a count time of $3 \mathrm{~s}$. Quantitative amounts of crystalline phases and amorphous material were estimated using the Total Pattern Analysis Solution (TOPAS) program (v. 4.2, Bruker AXS). This program calculates diffraction patterns of the crystalline phases from their crystal structures, deriving line shapes from the instrumental geometry and crystallite sizes for each phase. It minimizes the difference between observed and calculated diffraction patterns by adjusting the scale factor for each phase (along with other parameters for background, crystallite size, etc.) in a least-squares algorithm. The scale factor is directly proportional to the quantity of material present and so can be used to derive a weight ratio between each of the phases. The known quantity of corundum added was used to place the quantities on an absolute scale and the estimate of amorphous material was then established from a difference calculation (i.e., the amount of "missing" material).

\footnotetext{
${ }^{1}$ PNNL Technical Procedure: Operation of the MARS 5 Microwave Accelerated Reaction System. AGG-MARS$001 \operatorname{Rev} 3.2011$.
} 


\subsubsection{Scanning Electron Microscopy and Energy-Dispersive Spectroscopy}

Selected samples of each waste form monolith were dry-cut radially using thin-bladed circular diamond saw and the cut surfaces were analyzed by using an FEI ${ }^{\mathrm{TM}}$ Quanta $^{\mathrm{TM}}$ three-dimensional field emission gun scanning electron microscope equipped with an Oxford Instruments $80 \mathrm{~mm}^{2}$ silicon drift detector and INCA software. The surface was examined and images were collected in both secondaryelectron and backscatter-electron modes. Elemental maps were prepared to observe any major element associations and semi-quantitative analyses of selected regions were obtained.

\subsection{Compressive Strength Test}

Compressive strengths of 28-day cured non-radioactive Cast Stone, Ceramicrete, and DuraLith monoliths were measured following the test protocol specified by ASTM C-39 method (ASTM 2010). Compressive strength measurements were also conducted on monoliths that were thermal cycled and on monoliths that had been immersed in water.

\subsubsection{Thermal Cycling}

The thermal cycling test was performed following ASTM B553 (ASTM 1985) after 28 days of hydration. Three cylinders of each waste form were subjected to 30 thermal cycles as described in Sections 5.2.1 through 5.4.4 of ASTM B553 before testing for compressive strength. It is important to note that this thermal cycling procedure has not been revised by the American Society for Testing Materials; however, this method has been identified in the NRC Technical Position on Waste Form (NRC 1991) for conducting thermal cycling tests on waste forms. The 600-liter environmental chamber, Envirotronics model EnviroFST600 ${ }^{1}$ shown in Figure 4.1, was used for this experiment. For thermal cycling, the upper and lower temperatures were set at $60{ }^{\circ} \mathrm{C}$ and $-40{ }^{\circ} \mathrm{C}$ respectively.

After 28 days of curing, three specimens of each waste were subjected to thermal cycling test using a temperature-controlled environmental chamber. After placing the specimens in the chamber, the temperature was raised from 20 to $60{ }^{\circ} \mathrm{C}$ during a one-hour period. The temperature was maintained at $60{ }^{\circ} \mathrm{C}$ for an hour, and decreased back to $20^{\circ} \mathrm{C}$ during an hour's time. Next, the temperature was held at $20{ }^{\circ} \mathrm{C}$ for an hour, then reduced from 20 to $-40{ }^{\circ} \mathrm{C}$ during the next hour and then held at $-40{ }^{\circ} \mathrm{C}$ for an hour and raised back to $20^{\circ} \mathrm{C}$ during the following hour. The temperature was allowed to stay at $20{ }^{\circ} \mathrm{C}$ for an hour, which completed a single thermal cycle within 8 hours. A total of 30 thermal cycles were performed on the specimens within 10 days. After completing the thermal cycling, the specimens were photographed and then subjected to compressive strength tests.

\footnotetext{
${ }^{1}$ http://pierryinteractive.com/enviro/main/fst.html
} 


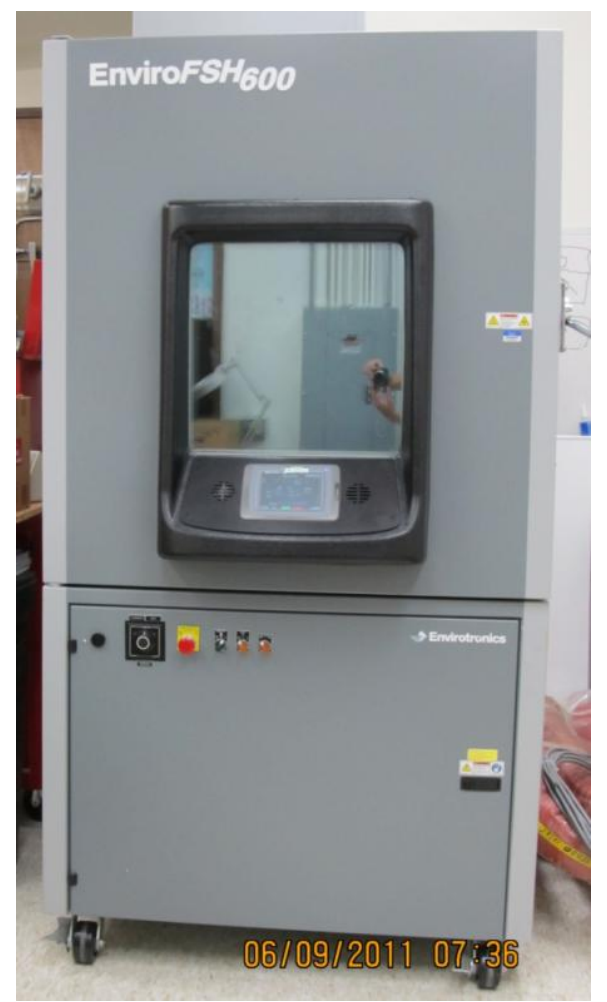

Figure 4.1. The Environmental Chamber Used for Thermal Cycling of Secondary Waste Forms

\subsubsection{Water Immersion Treatment}

To evaluate any degradation after 90-day water immersion, three specimens of each secondary waste form were immersed in DIW for 90 days. The water immersion test procedure basically followed the ANSI/ANS 16.1 test procedure (ANSI/ANS 2003), which is a 90-day semi-dynamic leach experiment. This test consists of submerging a monolithic sample (with a fixed geometry) in DIW at a fixed liquidvolume to solid geometric surface-area ratio $(10 \pm 0.2 \mathrm{~cm})$ and sampling (also changing) DIW at fixed total elapsed times ( 2 hours, 7 hours, 1 day, 2 days, 3 days, 4 days, 5 days, 19 days, 47 days, and 90 days). No chemical analysis was performed on leached solution because it is not required as part of the 90-day water immersion tests. The immersed specimens were supported by a polystyrene pad with a hole for allowing DIW access to the bottom parts of the specimens. After 90 days, the specimens were taken out of the DIW, and the compressive strength was measured.

\subsubsection{Ambient-Air Storage of Test Specimens}

Three monoliths of each waste form were stored in the ambient air for 90 days. This set of specimens was tested to provide reference data for 90-day water-immersed specimens. Compressive strength testing of this series was performed on the same day as that of the 90-day water-immersed specimens.

\subsubsection{Compressive Strength Test}

Compressive strength tests were conducted on 1) 28-day cured samples, 2) specimens subjected to 30 thermal cycles 3 ) water-immersed (90 day) specimens, and 4) ambient-air cured (90 day) specimens. 
The compressive strength tests of the cylindrical specimens were conducted as specified by the American Society for Testing and Materials (ASTM) Standard Procedure C-39/C39M (ASTM 2010), which is used to determine the compressive strength of cylindrical samples. According to the test method, a sample is loaded into the testing apparatus so that the axis of the specimen is aligned with the center of thrust of the spherically seated block of the testing apparatus. Before testing the specimen, the load indicator is set to zero. The loading is applied continuously without any shock at a stress rate of $0.25 \pm 0.05 \mathrm{MPa} / \mathrm{s}(35 \pm 7 \mathrm{psi} / \mathrm{s})$. The designated rate of movement should be maintained at least during the latter half of the anticipated loading phase. The loading is maintained until the load indicator starts to decrease steadily, and the specimen displays a well-defined fracture pattern as illustrated in the C-39/C39M test method. The compressive strength is calculated by dividing the maximum load imposed on the specimen during the test by the average cross-sectional area. The result is typically expressed to the nearest $0.1 \mathrm{MPa}(10 \mathrm{psi})$.

The compressive strength tests were conducted using a servo-hydraulic universal test machine (Instron ${ }^{\circledR}$ MTS system) shown in Figure 4.2. This apparatus has maximum load capacity of 20 kilopound force (kips-force) which is equivalent to $88.96 \mathrm{kN}$. The compressive load was applied until the complete fracture of the specimens was observed. The loading rate was set at $0.25 \mathrm{MPa}$ per second (29.4375 kN per minute) as specified by ASTM C-39, Standard Test Method for Compressive Strength of Cylindrical Concrete Specimens. Six specimens of Cast Stone 2-M Na, Ceramicrete, and DuraLith were tested under compression at 28 days. Three specimens of Cast Stone 4-M and 6-M Na were tested under compression at 28 days.

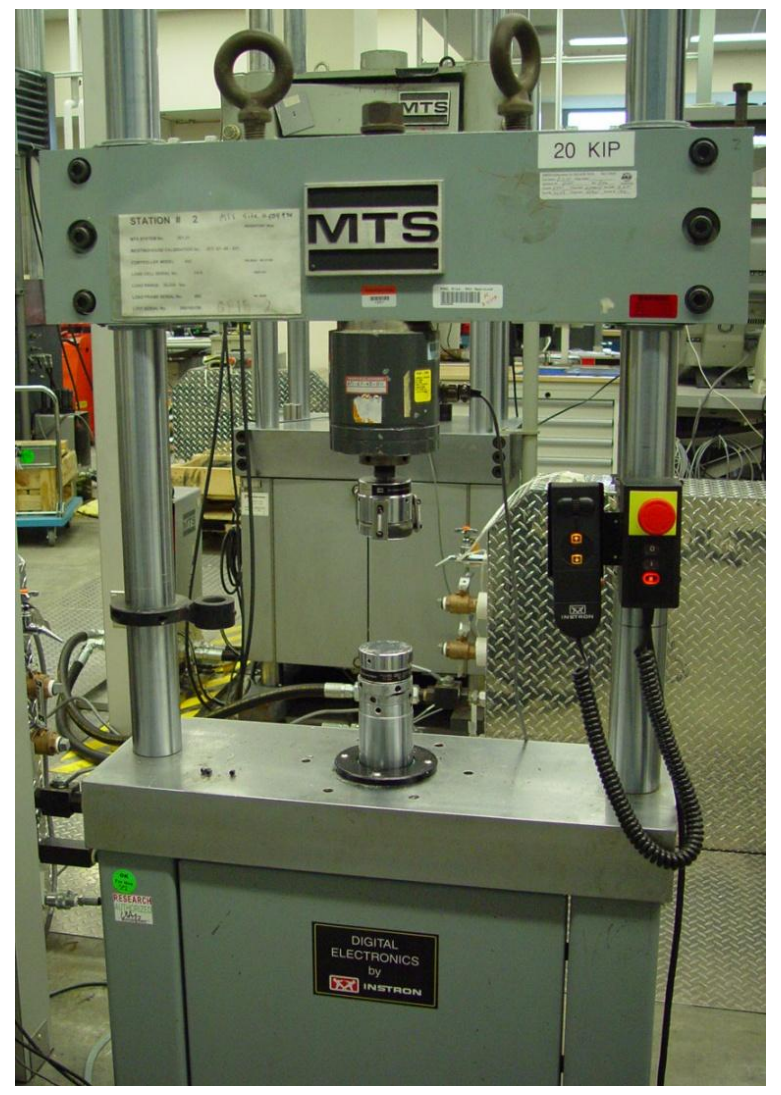

Figure 4.2. The Compressive Strength Test Apparatus 


\subsection{Free Liquids}

All specimens prepared for waste acceptance testing were examined for the presence of any free liquids right after casting or during curing. If free liquids were observed, a specimen was tested for free liquids as described in ANSI/ANS-55.1 Appendix B (ANSI/ANS 1992).

\subsection{Diffusivity Leach Tests}

The ANSI/ANS 16.1 leach test method (ANSI/ANS 2003) has typically been used to characterize the leaching of radioactive constituents in waste forms such as cementitious forms typically used to stabilize low-level wastes. The NRC calls for this test method in their Technical Position on Waste Form (NRC 1991). Recently, several other test methods have been developed to measure diffusive releases while overcoming at least perceived deficiencies with the ANSI/ANS 16.1 method. These methods include:

- ASTM C 1308, Standard Test Method for Accelerated Leach Test for Diffusive Releases from Solidified Waste and a Computer Program to Model Diffusive, Factional Leaching from Cylindrical Waste Forms (ASTM 2008).

- EPA Draft Method 1315, Mass Transfer Rates of Constituents in Monolithic or Compacted Granular Materials Using as Semi-Dynamic Tank Leaching Test (EPA 2009b)

Table 4.1 shows a comparison of key parameters for the three test methods. The Cast Stone, Ceramicrete, and DuraLith waste forms were tested using all three monolith leach test methods as shown in Table 3.1. The test monoliths were prepared with secondary waste simulant spiked with ${ }^{99} \mathrm{Tc}$ except for those ANSI/ANS 16.1 specimens that were subsequently subjected to compressive strength measurements after 90 days leaching. Deionized water was used as the leachant in all experiments. All tests were conducted at ambient room temperature on 2-inch-diameter $\mathrm{x} 4$-inch-high cylinders. Surface areas were based on the geometric surface areas of the specimens. In a recent NRC report, Ebert (2010) has recommended an alternate leaching interval sequence for the ASTM 1308 method (Table 4.1). Ebert's proposed leaching intervals are designed to help distinguish between diffusion-controlled and affinity-controlled release. In the current set of waste acceptance testing, the original ASTM C1308 intervals were used. The modified time intervals proposed by Ebert (2010) can be used in future testing to understand release mechanisms in support of performance assessment analyses. A brief description of each of the leach test methods follows. 
Table 4.1. Comparison of Diffusivity Leach Test Methods

\begin{tabular}{|c|c|c|c|c|}
\hline \multirow[b]{3}{*}{ Sample \# } & \multirow[b]{2}{*}{ ANS 16.1} & \multicolumn{2}{|c|}{ ASTM C1308 } & \multirow[b]{2}{*}{ EPA 1315} \\
\hline & & ASTM & Ebert & \\
\hline & \multicolumn{4}{|c|}{ Sampling Days } \\
\hline 1 & 0.083 & 0.083 & 1 & 0.083 \\
\hline 2 & 0.29 & 0.29 & 2 & 1 \\
\hline 3 & 1 & 1 & 3 & 2 \\
\hline 4 & 2 & 2 & 4 & 7 \\
\hline 5 & 3 & 3 & 5 & 14 \\
\hline 6 & 4 & 4 & 6 & 28 \\
\hline 7 & 5 & 5 & 14 & 42 \\
\hline 8 & 19 & 6 & 21 & 49 \\
\hline 9 & 47 & 7 & 28 & 63 \\
\hline 10 & 90 & 8 & 35 & \\
\hline 11 & & 9 & 42 & \\
\hline 12 & & 10 & 49 & \\
\hline 13 & & 11 & 56 & \\
\hline \multicolumn{5}{|c|}{ Test Parameters } \\
\hline Solution & DIW & DIW, & $\mathrm{CS}^{(\mathrm{a})}$ & DIW \\
\hline Temp $\left({ }^{\circ} \mathrm{C}\right)$ & 17.5 to 27.5 & $20 \pm 1 \mathrm{a}$ & $p$ to 50 & $20 \pm 2$ \\
\hline Sample Diameter & $\geq 1 \mathrm{~cm}$ & $\geq 2$ & & $\geq 5 \mathrm{~cm}$ \\
\hline Dia. - Ht. Ratio & $1: 0.2$ to $1: 5$ & $1: 1$ & & Not specified \\
\hline Leachant Vol. & $10 \times$ geometric surf area & $10 \mathrm{x}$ geom & surf area & $9 \pm 1 \times$ geometric surf area \\
\hline
\end{tabular}

\subsubsection{ANSI/ANS 16.1 Leach Test}

The ANSI/ANS-16.1-2003 test (ANSI/ANS 2003) is a 90-day semi-dynamic leach experiment that consists of submerging a monolithic sample (with a fixed geometry) in DIW at a fixed liquid-volume to solid-geometric surface-area ratio and replacing all the leachate at fixed periods of time. The leachates are then analyzed for key constituents.

The geometric surface area used in this test method is calculated from the cylindrical dimensions of the cylindrical monolith. At each of the ten predetermined leaching intervals, the leaching solution was exchanged with fresh leachant (DIW). The cylindrical monolith samples ( 2-inch diameter by $\sim$-inch height) were placed into the center of leaching vessels and contacted with DIW to maintain the appropriate leachant-volume to sample-surface-area ratio of $10 \pm 0.2(\mathrm{~cm})$. Sample stands and holders were used to maximize the contact area of the samples with the leaching solution. For tests conducted at PNNL, the experimental vessels were covered with lids between the sampling/replacement intervals. The cumulative leaching times at which solution exchanges were made for these experiments were 2,7 , and 24 hours and 2, 3, 4, 5, 19, 47, and 90 days. Leachate samples collected during these intervals were stored in screw-top containers with minimal head space until the entire batch of collected samples was submitted for chemical analysis.

The effective diffusivity is calculated based on a semi-infinite solid and is defined as:

$$
\mathrm{D}=\pi\left[\frac{\left(\mathrm{a}_{\mathrm{n}} / \mathrm{A}_{\mathrm{o}}\right)}{(\Delta \mathrm{t})_{\mathrm{n}}}\right]^{2}\left(\frac{\mathrm{V}}{\mathrm{S}}\right)^{2} \mathrm{~T}
$$


where: $\mathrm{D}=$ effective diffusivity $\left(\mathrm{cm}^{2} / \mathrm{s}\right)$ during leach interval

$\mathrm{V}=$ volume of specimen $\left(\mathrm{cm}^{3}\right)$

$\mathrm{S}=$ geometric surface area of the specimen $\left(\mathrm{cm}^{2}\right)$

$\mathrm{T}=$ leaching time representing the "mean time" of leaching interval $\left.=\left[1 / 2\left(\mathrm{t}_{\mathrm{n}}^{1 / 2}+\mathrm{t}_{\mathrm{n}-1}\right)^{1 / 2}\right)\right]^{2}$

$a_{n}=$ quantity of an element released from the specimen during the leaching interval

$\mathrm{A}_{0}=$ Total quantity of an element in the specimen at the beginning of the first leaching interval

$\Delta \mathrm{t}_{\mathrm{n}}=$ duration of the $\mathrm{n}^{\text {th }}$ leaching interval (s)

The mean observed diffusivity for each constituent can be determined by taking the average of the interval observed diffusivity, and typically the standard deviation is also reported. Alternatively, the diffusivity for each constituent can also be calculated using the analytical solution, Equation 6.1, for simple radial diffusion from a cylinder into an infinite bath as presented by Crank (1986).

If the leaching fraction exceeds 0.20 at any time $t$, the effective diffusivity should be calculated from a shape-specific empirical solution provided by mass-transport equations to account for departure from the semi-infinite source assumption. Tabulated values of time factor $\mathrm{G}$ are provided in Table A1 of (ANSI/ANS 2003). An appropriate $G$ value is selected from Table A1 that corresponds to the calculated leaching fraction and length-to-diameter ratio of the specimen. This $\mathrm{G}$ value is used to calculate the diffusivity as:

$$
\mathrm{D}=\frac{G d^{2}}{t}
$$

where: $\mathrm{G}=$ dimensionless time factor for the cylindrical specimen

$\mathrm{d}=$ diameter of the cylinder $(\mathrm{cm})$

$\mathrm{t}=$ elapsed leaching time since the beginning of the first leaching interval (s)

The LI, the parameter derived directly from immersion test results, evaluates diffusion-controlled contaminant release with respect to time. The LI is used as a performance criterion to assess whether a stabilizing waste form is likely to be acceptable for subsurface burial and disposal in the target waste repository. In most cases, the immobilizing waste form is considered effective when the LI value is equal to or greater than 9. The LI is calculated by Equation 4.3.

$$
L I_{n}=-\log \left(D_{n}\right)
$$

where $\mathrm{LI}_{\mathrm{n}}$ is the leachability index, and $D_{n}$ is the effective diffusivity $\left(\mathrm{cm}^{2} / \mathrm{s}\right)$ for components of interest during the leach interval $n$. Typically, the average LI is calculated and reported from the individual intervallic $\mathrm{D}_{\mathrm{n}}$ values for each monolith

\subsubsection{ASTM C1308-08 Leach Test}

The ASTM C1308-08 test is an 11-day accelerated leach test in which monolithic samples of fixed geometry are immersed in a selected leachant, such as DIW, synthetic or actual ground water, or a chemical solution. A specimen with a diameter-to-length ratio of 1:1 or 1:2 is immersed at a fixed liquidvolume to solid-surface-area ratio with solution sampling conducted at fixed time intervals.

The geometric surface area used in this test method is calculated from the cylindrical dimensions of the sample. At each of the 13 predetermined leaching intervals, the leaching solution is exchanged with 
fresh leachant (DIW). The cylindrical monolith samples ( 2-inch diameter by $\sim 4$-inch height) are placed into the center of leaching vessels and mixed with DIW to maintain the appropriate leachant volume-tosample surface area of $10 \pm 0.2(\mathrm{~cm})$. Sample stands and holders are used to maximize the contact area of the samples with the leaching solution. In between the sampling/replacement intervals, the experimental vessels are covered with lids. The leaching times at which solution exchanges are made range from 2 hours to 11 days. The test is conducted under ambient temperature conditions and the leachate samples collected during these intervals are stored in screw-top containers with minimal head space until the entire batch of collected samples is submitted for chemical analysis.

The diffusivity for each constituent of interest is calculated using the analytical solution based on the assumption that contaminant release occurs from a semi-infinite medium:

$$
D_{e}=\frac{\pi}{t_{n}}\left[\frac{\sum a_{n}}{A_{0}} \frac{V}{2 S}\right]^{2}
$$

where $D_{\mathrm{e}}=$ effective diffusion coefficient of a specific constituent for cumulative leaching interval $n$

$\mathrm{t}_{\mathrm{n}}=$ cumulative time

$a_{n}=$ total amount of the species of interest released in all leaching intervals through time $t_{n}$

$\mathrm{A}_{0}=$ total quantity of an element in the specimen before leaching

$\sum \mathrm{a}_{\mathrm{n}} / \mathrm{A}_{0}=$ cumulative fraction leached during leaching interval $\mathrm{t}_{\mathrm{n}}$

$\mathrm{V}=$ volume of specimen

$\mathrm{S}=$ geometric surface area of the specimen

Unlike the ANS-16.1 and EPA 1315 methods, the ASTM 1308 method calculates a diffusion coefficient based on a cumulative release rather than an incremental release. It effectively calculates an average over the duration of the test.

The LI, the parameter derived directly from immersion test results, evaluates diffusion-controlled contaminant release with respect to time. The LI is used as a performance criterion to assess whether a stabilizing waste form is likely to be acceptable for subsurface burial and disposal in the target waste repository. In most cases, the immobilizing waste form is considered effective when the LI value is equal to or greater than 9. The LI is calculated by Equation 4.5.

$$
L I_{n}=-\log \left(D_{n}\right)
$$

where: $\mathrm{LI}_{\mathrm{n}}$ is the Leachability Index, and $D_{n}$ is the effective diffusivity $\left(\mathrm{cm}^{2} / \mathrm{s}\right)$ for components of interest during successive cumulative leach intervals.

\subsubsection{EPA 1315 Leach Test}

The draft EPA Method 1315 (EPA 2009b) is a semi-dynamic leach experiment that consists of submerging a monolithic sample in DIW at a fixed liquid-volume to solid-geometric-surface-area ratio. The sampling was done at fixed periods of time at cumulative leaching times $0.08,1,2,7,14,28,42,49$, and 63 days (EPA 2009b). At each sampling interval, the leaching fluid was removed and replaced with fresh fluid. A schematic of this process is shown in Figure 4.3. 


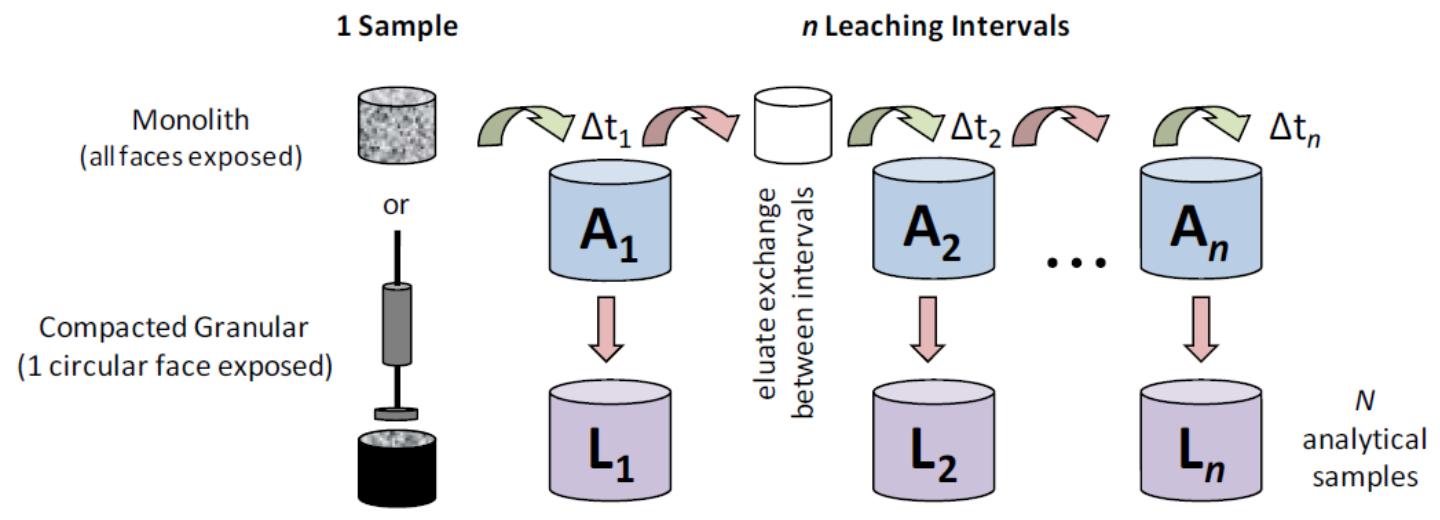

Figure 4.3. EPA 1315 Testing Scheme (Source: EPA 2009b)

The geometric surface area is used in this test method and is calculated from the dimensions of the cylindrical monolith. At each of the nine pre-determined leaching intervals, the sample mass is recorded, and the leaching solution is changed. This method is similar to ANSI/ANS 16.1 (ANSI/ANS 2003), but the leaching intervals are modified, and the developers of this method claim that the process of mass transfer can be interpreted by more complex release models that account for physical retention of the porous medium and chemical retention at the pore wall through geochemical speciation modeling.

In this test, a cylindrical monolith samples ( 2-inch diameter by $\sim 4$-inch height) are placed into the centers of a leaching vessels and mixed with DIW to maintain a solid-to-solution ratio of $9 \pm 1 \mathrm{~mL}$ of leachant per $\mathrm{cm}^{2}$ of sample. Sample stands and holders are used to maximize the contact area of the sample with the leaching solution. In between the sampling/replacement intervals, the experimental vessels are covered with lids. The solution exchanges are made at cumulative leaching times of 2 hours and 1, 2, 7, 14, 28, 42, 49, and 63 days. Chemical analyses of the leachates are conducted following filtration using a $0.45-\mu \mathrm{m}$ syringe filter.

The observed diffusivity for each constituent is calculated using the analytical solution, Equation 4.6, for simple radial diffusion from a cylinder into an infinite bath as presented by Crank (1986).

$$
D_{i}=\pi\left[\frac{M_{t i}}{2 \rho C_{0}\left(\sqrt{t_{i}}-\sqrt{t_{i-1}}\right)}\right]^{2}
$$

where $\quad \mathrm{D}_{i}=$ mean observed diffusivity of a specific constituent for leaching interval, $i\left(\mathrm{~m}^{2} / \mathrm{s}\right)$

$\mathrm{M}_{\mathrm{ti}}=$ mass released per unit area of the specimen during leaching interval $i\left(\mathrm{mg} / \mathrm{m}^{2}\right)$

$\mathrm{t}_{i}=$ cumulative contact time after leaching interval, $i$ (s)

$\mathrm{t}_{i-1}=$ cumulative contact time after leaching interval, $i-1(\mathrm{~s})$

$\mathrm{C}_{\mathrm{o}}=$ initial leachable content $(\mathrm{mg} / \mathrm{kg})$

$\rho=$ sample density $\left(\mathrm{kg} / \mathrm{m}^{3}\right)$

The mean observed diffusivity for each constituent can be determined by taking the average of the interval observed diffusivity and the mean is usually reported with the standard deviation.

The LI, the parameter derived directly from immersion test results, evaluates diffusion-controlled contaminant release with respect to time. The LI is used as a criterion to assess whether 
solidified/stabilized waste is likely to be acceptable for subsurface disposal in waste repositories. In most cases, the solidified waste is considered effectively treated when the LI value is equal to or greater than 9. The LI was calculated with Equation (4.7)

$$
L I_{n}=-\log \left[D_{i}\right]
$$

where $L I$ is the leachability index and $D_{n}$ is the effective diffusivity for elements of interest $\left(\mathrm{cm}^{2} / \mathrm{s}\right)$ during the leach interval $n$.

\subsubsection{EPA 1313 Leach Test}

The EPA 1313 test method (EPA 2009a) has been used on Cast Stone and DuraLith samples tested during the Phase I investigations of candidate secondary waste forms (Pierce et al., 2010b). Therefore, in this set of tests, EPA 1313 leaching was conducted on only Ceramicrete samples. The EPA Method 1313 (Liquid-Solid Partitioning as a Function of Extract $\mathrm{pH}$ ) is a static test method where a set of parallel extraction experiments are conducted in dilute acid- or base-laden DIW at a fixed $\mathrm{pH}$ (pH range from 4 to 12) and fixed liquid-to-solid ratio (10 mL/g) (EPA 2009a) using crushed subsamples of the waste form.

Before initiating the static test, a series of pre-titrations is conducted at a fixed liquid-to-solid ratio (10 $\mathrm{mL} / \mathrm{g}$ ) using <0.3-mm-sized material. After a 24-hour period of mixing in the absence of acid or base additions, the sample slurry is centrifuged, and the supernatant is removed and used to determine the $\mathrm{pH}$. If the measured $\mathrm{pH}$ of the leachate solution is high ( $\mathrm{pH} \sim 12$ to 13), a pre-titration is performed using dilute $\mathrm{HNO}_{3}$ additions to decrease the $\mathrm{pH}$ from 12 to lower targeted values after 24 hours of equilibration. Analytical-grade $\mathrm{HNO}_{3}$ (Optima) is used to prepare a solution of 2-N $\mathrm{HNO}_{3}$ for these titration experiments.

For the test conducted at PNNL, the pre-titration results were used to prepare Ceramicrete test samples by mixing $10 \mathrm{~g}$ of $<0.3$-mm-sized material with a predetermined amount of $2-\mathrm{N}^{-} \mathrm{HNO}_{3}$ and bringing the samples to volume with DIW. All samples were placed on a platform shaker and allowed to mix at room temperature $\left(23 \pm 2^{\circ} \mathrm{C}\right)$ for 24 hours. After mixing, the extractant vessels were centrifuged (at minimum $4000 \pm 100 \mathrm{RPM}$ ) for $10 \pm 2$ minutes, and the decanted clear supernatant was filtered using a $0.45-\mu \mathrm{m}$ polypropylene membrane syringe filter, collected in a vial with minimal head space, and submitted for chemical analysis.

\subsubsection{EPA 1316 Leach Test}

Similar to EPA Method 1313, EPA Method 1316 (EPA 2009c) also is a static test method that uses DIW as the leachant instead of a dilute acid or base at a variety of liquid-to-solid ratios (EPA 2009b). In a previous study, specimens of Cast Stone and DuraLith were leach tested using this method (Pierce et al., 2010b). Therefore, in the current study only Ceramicrete samples were tested using the EPA 1316 method.

The purpose of this test method is to evaluate the effect of differing liquid-to-solid ratios on the release of contaminants. These experiments were conducted by adding DIW to the test vessel containing a predetermined amount of crushed Ceramicrete material $(<0.3 \mathrm{~mm}$ in particle size $)$ at three different liquid-to-solid ratios $(10,5$, and $2 \mathrm{~mL} / \mathrm{g})$. After preparation, all the vessels were placed on a platform 
shaker and allowed to mix for 24 hours. After the 24-hour contact time was complete, the slurry samples were centrifuged and clear supernatants were filtered using a syringe filter $(0.45-\mu \mathrm{m}$ size polypropylene membrane). The filtrate was collected in vials with minimal head space and submitted for chemical analyses.

\subsection{Toxicity Characteristic Leaching Procedure (EPA 1311)}

The TCLP is the current regulatory test procedure (EPA 1999) used to confirm whether a solid waste, including waste forms that are destined for disposal at a waste repository, will meet the restrictions associated with several regulated hazardous metals and selected regulated organic compounds. This test is conducted to make sure that the waste forms meet the requirements described for land disposal facilities (40 CFR Part 268). The secondary waste stream is projected to include RCRA metals including Cr, Ag, $\mathrm{As}, \mathrm{Cd}, \mathrm{Hg}$, and $\mathrm{Pb}$. In addition, some of the dry materials may include these same and other hazardous materials. Non-radioactive samples of Cast Stone, Ceramicrete, and DuraLith were sent to an EPA accredited laboratory for the TCLP test. The results were compared with the UTS in 40 CFR 268 as shown in Table 4.2. Following is a brief synopsis of the EPA 1311 TCLP method.

Table 4.2. Universal Treatment Standards from 40 CFR Part 268

\begin{tabular}{lc}
\hline $\begin{array}{c}\text { Regulated } \\
\text { Constituent }\end{array}$ & $\begin{array}{c}\text { TCLP Leachate Concentration } \\
(\mathrm{mg} / \mathrm{L})\end{array}$ \\
\hline RCRA Metals & \\
\hline Arsenic & 5.00 \\
Barium & 21.00 \\
Cadmium & 0.11 \\
Chromium & 0.60 \\
Lead & 0.75 \\
Mercury & 0.025 \\
Selenium & 5.70 \\
Silver & 0.14 \\
\hline \multicolumn{2}{c}{ Underlying Hazardous Constituents } \\
\hline Antimony & 1.15 \\
Beryllium & 1.22 \\
Nickel & 11.00 \\
Thallium & 0.20 \\
\hline
\end{tabular}

For wastes containing greater than or equal to $0.5 \%$ solids, the liquid, if any, is separated from the solid phase and stored for later analysis; the particle size of the solid phase is reduced, if necessary. The solid phase is extracted with an amount of extraction fluid equal to 20 times the weight of the solid phase. The extraction fluid used is a function of the alkalinity of the solid phase of the waste. Particle-size reduction is required, unless the solid has a surface area per gram of material equal to or greater than $3.1 \mathrm{~cm}^{2}$, or is smaller than $1 \mathrm{~cm}$ in its narrowest dimension (i.e., is capable of passing through a $9.5-\mathrm{mm}$ (0.375 in.) standard sieve). If the surface area is smaller or the particle size larger than described above, the solid portion of the waste is prepared for extraction by crushing, cutting, or grinding the waste to a specific surface area or particle size. The extraction vessel containing the solid/solution mixture is then 
rotated at $30 \pm 2 \mathrm{rpm}$ for $18 \pm 2$ hours at $23 \pm 2{ }^{\circ} \mathrm{C}$. Following the extraction, the material in the extractor vessel is separated into its component liquid and solid phases by filtering it through a new glass fiber filter. After collecting the TCLP extract, the $\mathrm{pH}$ of the extract is recorded. An aliquot of the extract is taken for analysis. The aliquots must be acidified with nitric acid to $\mathrm{pH}<2$. If any precipitation is observed after adding nitric acid to a small aliquot of the extract, then the remaining portion of the extract for metals analyses is not acidified, and the extract is analyzed as soon as possible. All aliquots must be stored under refrigeration $\left(4^{\circ} \mathrm{C}\right)$ until analyzed. 


\subsection{Results and Discussion}

\subsection{Chemical Analysis}

The chemical compositions of the waste forms are listed in Table 5.1. These compositions reflect the compositions of the major ingredients used for formulating these waste forms. For instance, the major ingredients in Cast Stone are Class F fly ash, BFS and simulant. Therefore, the chemical composition of Cast Stone is dominated by Al, Ca, Si, O, LOI (carbonate, oxalate etc.) that account for $\sim 80 \%$ of the waste mass.

Ceramicrete is a potassium phosphate-based waste form that contains Class $\mathrm{C}$ fly ash and magnesium oxide as the main dry ingredients and the chemical composition of this waste form indicates the dominant components on the oxide basis to be $\mathrm{K}, \mathrm{Mg}, \mathrm{P}, \mathrm{Ca}, \mathrm{Al}, \mathrm{H}$, and $\mathrm{LOI}$ ( $90 \%$ of waste mass). Of all the waste forms, Ceramicrete has the highest water content $(\sim 16 \%)$ perhaps due to the presence of hydration water of the phosphate mineral that is the principal crystalline component in this waste form (See Section 5.2).

Table 5.1. Chemical Composition of Cast Stone, Ceramicrete and DuraLith Waste Forms

\begin{tabular}{|c|c|c|c|c|c|}
\hline \multirow[b]{2}{*}{ Component } & Cast Stone 2M & Cast Stone 4M & Cast Stone 6M & Ceramicrete & DuraLith \\
\hline & \multicolumn{5}{|c|}{ Composition (\%) } \\
\hline $\mathrm{Ag}_{2} \mathrm{O}$ & 0.0002 & 0.0003 & 0.0002 & 0.0210 & 0.0210 \\
\hline $\mathrm{Al}_{2} \mathrm{O}_{3}$ & 13.81 & 13.20 & 12.53 & 6.84 & 11.26 \\
\hline $\mathrm{BaO}$ & 0.12 & 0.11 & 0.10 & 0.27 & 0.04 \\
\hline $\mathrm{CaO}$ & 24.04 & 22.84 & 21.21 & 9.34 & 12.77 \\
\hline $\mathrm{Fe}_{2} \mathrm{O}_{3}$ & 3.06 & 2.86 & 2.68 & 2.17 & 1.70 \\
\hline $\mathrm{K}_{2} \mathrm{O}$ & $<1.40$ & $<1.33$ & $<1.41$ & 11.34 & 4.54 \\
\hline $\mathrm{MgO}$ & 2.44 & 2.28 & 2.17 & 11.40 & 3.32 \\
\hline $\mathrm{Na}_{2} \mathrm{O}$ & 3.53 & 5.49 & 7.92 & 1.73 & 4.73 \\
\hline $\mathrm{N}_{2} \mathrm{O}_{5}$ & 1.02 & 2.04 & 3.28 & 0.67 & 2.09 \\
\hline $\mathrm{P}_{2} \mathrm{O}_{5}$ & $<0.92$ & $<0.87$ & $<0.93$ & 17.07 & $<0.91$ \\
\hline $\mathrm{SO}_{3}$ & 0.93 & 0.87 & 0.81 & 0.00 & 0.80 \\
\hline $\mathrm{SiO}_{2}$ & 32.64 & 31.36 & 28.95 & 12.77 & 39.51 \\
\hline $\mathrm{SnO}_{2}$ & 0.20 & 0.19 & 0.20 & 1.00 & 1.03 \\
\hline $\mathrm{TiO}_{2}$ & 1.64 & 1.52 & 1.41 & 0.53 & 0.46 \\
\hline $\mathrm{H}_{2} \mathrm{O}$ & 8.08 & 9.29 & 11.48 & 7.65 & 9.85 \\
\hline LOI* & 3.87 & 5.08 & 6.42 & 15.80 & 6.70 \\
\hline Total & 97.72 & 99.32 & 101.51 & 98.59 & 99.71 \\
\hline \multicolumn{6}{|c|}{ Trace Component Concentrations $(\mu \mathrm{g} / \mathrm{g}$ ) } \\
\hline${ }^{99} \mathrm{Tc}$ & $\begin{array}{c}1.06 \\
(18.0 \mathrm{nCi} / \mathrm{g})\end{array}$ & $\begin{array}{c}2.12 \\
(36.0 \mathrm{nCi} / \mathrm{g})\end{array}$ & $\begin{array}{c}3.34 \\
(56.8 \mathrm{nCi} / \mathrm{g})\end{array}$ & $\begin{array}{c}0.67 \\
(11.4 \mathrm{nCi} / \mathrm{g})\end{array}$ & $\begin{array}{c}2.09 \\
(35.5 \mathrm{nCi} / \mathrm{g})\end{array}$ \\
\hline $\operatorname{Re}$ & 1.93 & 4.41 & 6.30 & $<1.34$ & 3.28 \\
\hline
\end{tabular}


DuraLith is a Si-rich waste form and on the oxide basis $\mathrm{Si}$ accounts for nearly $40 \%$ of the waste mass. Aluminum, Ca, alkalis (K and Na), LOI, and water comprise $\sim 50 \%$ of the mass of DuraLith.

Concentrations of trace components namely, ${ }^{99} \mathrm{Tc}$ and Re originating as spikes in simulant are also listed in Table 5.1. Depending on the Na molarity of the simulant, the Cast Stone monoliths contained

${ }^{99} \mathrm{Tc}$ concentrations that ranged from $1.06 \mu \mathrm{g} / \mathrm{g}$ (Cast Stone $2 \mathrm{M}$ ) to $3.34 \mu \mathrm{g} / \mathrm{g}$ (Cast Stone 6M). Similarly, Re concentrations in Cast Stone specimens ranged from $1.93 \mu \mathrm{g} / \mathrm{g}$ to $6.30 \mu \mathrm{g} / \mathrm{g}$ respectively. Compared to all other waste form specimens, Ceramicrete prepared with 2-M Na simulant contained the lowest concentrations of both the spikes $\left({ }^{99} \mathrm{Tc}: 0.67 \mu \mathrm{g} / \mathrm{g}\right.$, Re: $<1.34 \mu \mathrm{g} / \mathrm{g}$ ). The concentrations of ${ }^{99} \mathrm{Tc}$ and Re in DuraLith were found to be $2.09 \mu \mathrm{g} / \mathrm{g}$ and $3.28 \mu \mathrm{g} / \mathrm{g}$ respectively. Iodine concentrations in aciddigested samples could not be measured due to volatilization losses.

\subsection{X-Ray Diffraction Analysis}

The phase identification and relative quantitation results for the three waste forms are summarized in Table 5.2. Figure 5.1 - Figure 5.5 show the individual diffraction traces (blue $=$ observed, red $=$ calculated, and grey = difference); in these figures the quantitative values refer to the total sample including added corundum. The amounts have been rescaled in the table to the original sample without added corundum.

All of the samples contained broad backgrounds indicative of amorphous material. To estimate the quantity of amorphous material, a weighed amount of corundum $\left(\alpha-\mathrm{Al}_{2} \mathrm{O}_{3}\right.$, approximately $\left.10 \mathrm{wt} \%\right)$ was mixed into each sample using a mortar and pestle and further diffraction patterns collected. The known quantity of corundum added was used to place the quantities on an absolute scale and the estimate of amorphous material was then established from a difference calculation (i.e., the amount of "missing" material). By difference calculations, the amorphous material contents were determined to be $\sim 84-88 \%$ in Cast Stone, $\sim 74 \%$ in Ceramicrete and $\sim 87 \%$ in DuraLith respectively (Table 5.2).

This is one of the more robust methods for quantitative phase analysis by XRD. It is, however, reliant on having crystal structures that accurately reflect the structure of compounds in the sample. Deviations from this, for example by elemental substitution, will introduce errors. Some of the patterns contained additional minor peaks, which could not be identified. The main effect of this is an overestimate of the amorphous content since any diffraction not modeled by the crystal structures included adds to the "missing" material. The peak heights of unidentified material crystalline phases compared to those of known phases suggest that the unidentified phase content in these waste forms is comparatively smallless than $5 \mathrm{wt} \%$. Taking these factors into consideration, the estimated uncertainty in the quantities of crystalline phases identified is less than $\pm 10 \%$ relative to the quantity given. The uncertainty is likely to be lower than this for crystalline phases with a more positive identification (e.g., quartz). The amorphous contents are best seen as upper limits, although it is unlikely that they are overestimated relative to crystalline phases by more than 10 or $15 \%$.

DuraLith contained $\sim 6.4 \%$ quartz and $\sim 5 \%$ albite. Minor amounts $(\sim 1.6-2.5 \%)$ of quartz were detected in all other waste forms. Only a trace amount (1.6\%) of calcite was present in DuraLith, whereas Cast Stone specimens contained $\sim 6-11 \%$ calcite. 
The principal crystalline components in Ceramicrete were a magnesium phosphate compound, struvite (19\%), and periclase (4.8\%). Periclase is one of the original ingredients in Ceramicrete and its presence in the monolith indicates that all periclase, as expected, did not react and undergo phase changes.

A small amount $(\sim 3.7 \%)$ of ettringite was found in one of Cast Stone specimens prepared using 2-M Na simulant.

A calcium silicate mineral, hatrurite $\left(\mathrm{Ca}_{3} \mathrm{SiO}_{5}\right)$, in quantities ranging from $\sim 1.5-3.6 \%$ was found only in Cast Stone specimens. The identification of hatrurite is somewhat tentative. This is mostly a high-temperature phase but provided the best match to a number of the observed XRD peaks. It is at least representative of similar phases in the diffraction database that have similar peaks. It is likely that this phase may originate from the blast furnace slag that is one of the principal ingredients $(\sim 30-34 \%)$ in Cast Stone formulation. The calculated hatrurite pattern is shown in dark green in Figure 5.3.

Table 5.2. Relative Quantities of Phases Identified in Cast Stone, Ceramicrete and DuraLith Specimens

\begin{tabular}{|c|c|c|c|c|c|}
\hline \multirow[b]{2}{*}{ Phase / Chemical Composition / ICDD PDF\# / Reference } & \multicolumn{5}{|c|}{ Waste Form Sample } \\
\hline & $\begin{array}{l}\text { Cast } \\
\text { Stone } 2 \mathrm{M} \\
\text { CS-11- } \\
\text { S1-2-601 }\end{array}$ & $\begin{array}{l}\text { Cast } \\
\text { Stone 4M } \\
\text { CS-11- } \\
\text { S1-4-401 }\end{array}$ & $\begin{array}{l}\text { Cast } \\
\text { Stone 6M } \\
\text { CS-11- } \\
\text { S1-6-504 }\end{array}$ & $\begin{array}{l}\text { Ceramicrete } \\
\text { CE-11-S1-2- } \\
\text { 10X }\end{array}$ & $\begin{array}{l}\text { DuraLith } \\
\text { GP-11-S1- } \\
6-310\end{array}$ \\
\hline $\begin{array}{l}\text { (a) Quartz / } \mathrm{SiO}_{2} / \text { 0-33-1161/ Natl. Bur. Stand. (U.S.) } \\
\text { Monogr. 25, v18, p } 61 \text { (1981) }\end{array}$ & $1.6 \%$ & $2.5 \%$ & $1.7 \%$ & $2.0 \%$ & $6.4 \%$ \\
\hline $\begin{array}{l}\text { (b) Periclase / MgO / 00-4-829 / Swanson \& Tatge. Natl. } \\
\text { Bur. Stand. (U.S.), Circ. 539, v1, p37 (1953) }\end{array}$ & & & & $4.8 \%$ & \\
\hline $\begin{array}{l}\text { (c) } \mathrm{K} \text {-Struvite / } \mathrm{KMgPO}_{4} \cdot 6 \mathrm{H}_{2} \mathrm{O} / 00-35-812 \text { / Natl. Bur. } \\
\text { Stand. (U.S.) Monogr. 25, v21, p102 (1985) }\end{array}$ & & & & $19.0 \%$ & \\
\hline $\begin{array}{l}\text { Calcite / } \mathrm{CaCO}_{3} / \text { 01-81-2027 / Maslen et al., Acta Cryst. } \\
\text { B49 } 636 \text { (1993) }\end{array}$ & $5.8 \%$ & $7.9 \%$ & $11.0 \%$ & & $1.4 \%$ \\
\hline $\begin{array}{l}\text { Albite / } \mathrm{NaAlSi}_{3} \mathrm{O}_{8} / 01-89-6430 \text { / Meneghinello et al., } \\
\text { Amer. Mineral. 84, } 1144 \text { (1999) }\end{array}$ & & & & & $4.8 \%$ \\
\hline $\begin{array}{l}\text { Ettringite } / \mathrm{Ca}_{6} \mathrm{Al}_{2}\left(\mathrm{SO}_{4}\right)_{3}(\mathrm{OH})_{12} \cdot 26 \mathrm{H}_{2} \mathrm{O} / 00-41-1451 \text {, } \\
\text { Goetz-Neunhoeffer \& Neubauer, Powder Diffraction } \\
21(4)(2006)\end{array}$ & $3.7 \%$ & & & & \\
\hline $\begin{array}{l}\text { Hatrurite / } \mathrm{Ca}_{3} \mathrm{SiO}_{5} / \text { 01-86-402, Mumme, Neues } \\
\text { Jahrbuch fuer Mineralogie. Monatshefte 1995(4) } 145 \\
\text { (1995), Reported in Phase Transitions, 38(3) } 127 \text { (1992) }\end{array}$ & $1.5 \%$ & $2.4 \%$ & $3.6 \%$ & & \\
\hline Amorphous & $88 \%$ & $87 \%$ & $84 \%$ & $74 \%$ & $87 \%$ \\
\hline $\begin{array}{l}\text { The crystal structures used for quantitative fit were from: } \\
\text { (a) Antao et al., Canadian Miner. 46, } 1501 \text { (2008), } \\
\text { (b) Bioocchi et al., Eur. J. Mineral. } 13871,(2001) \text {, } \\
\text { (c) Graeser et al., Eur. J. Mineral. } 20629 \text { (2008) } \\
\text { PDF\#: Powder Diffraction File number }\end{array}$ & & & & & \\
\hline
\end{tabular}




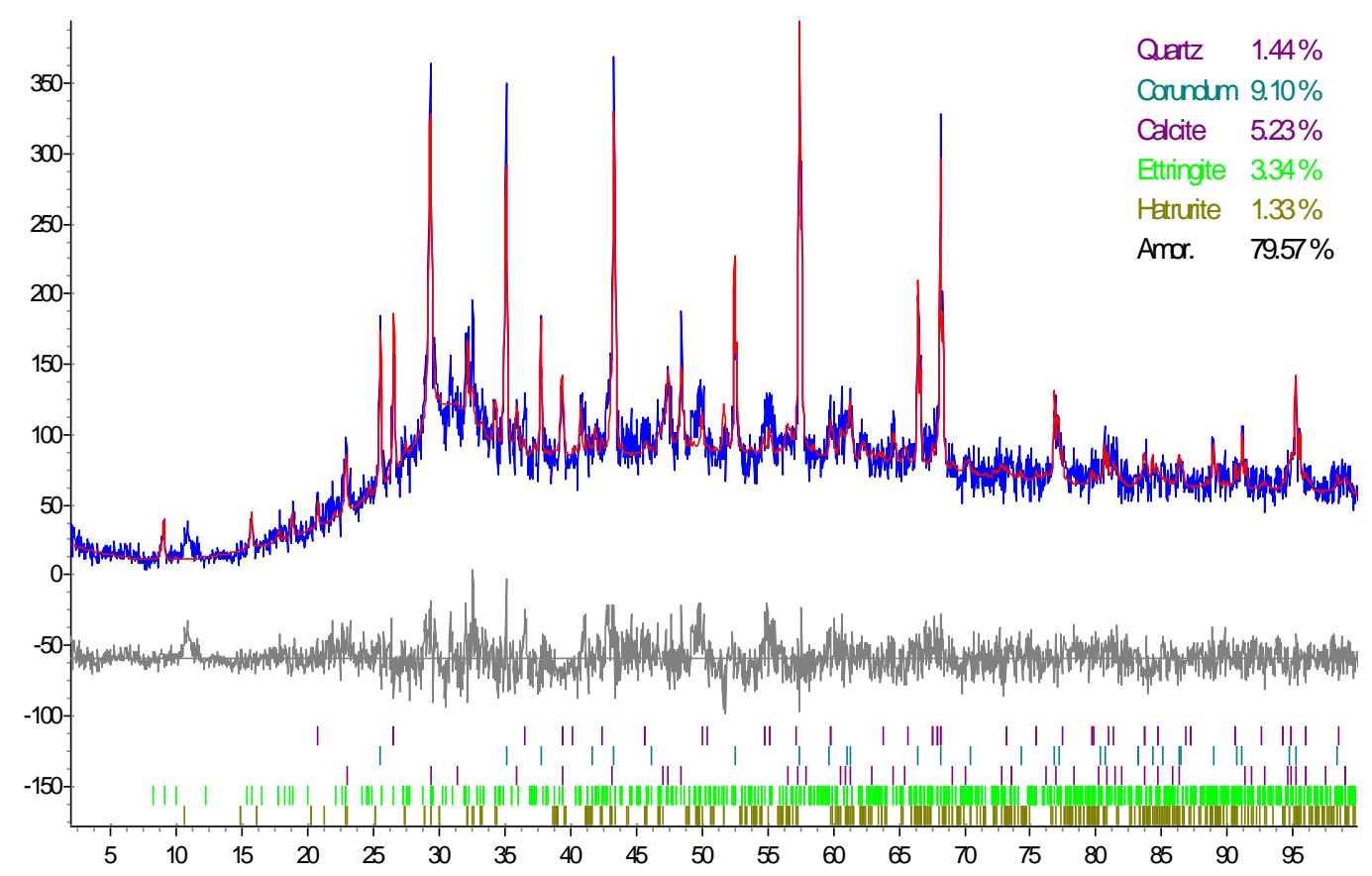

Figure 5.1. Phase Identification for Cast Stone Sample CS-11-S1-2-601. Corundum has been added as an internal standard. The TOPAS crystal structure fit and the residual are also shown. $($ Blue $=$ observed, red $=$ calculated grey $=$ difference $)$.

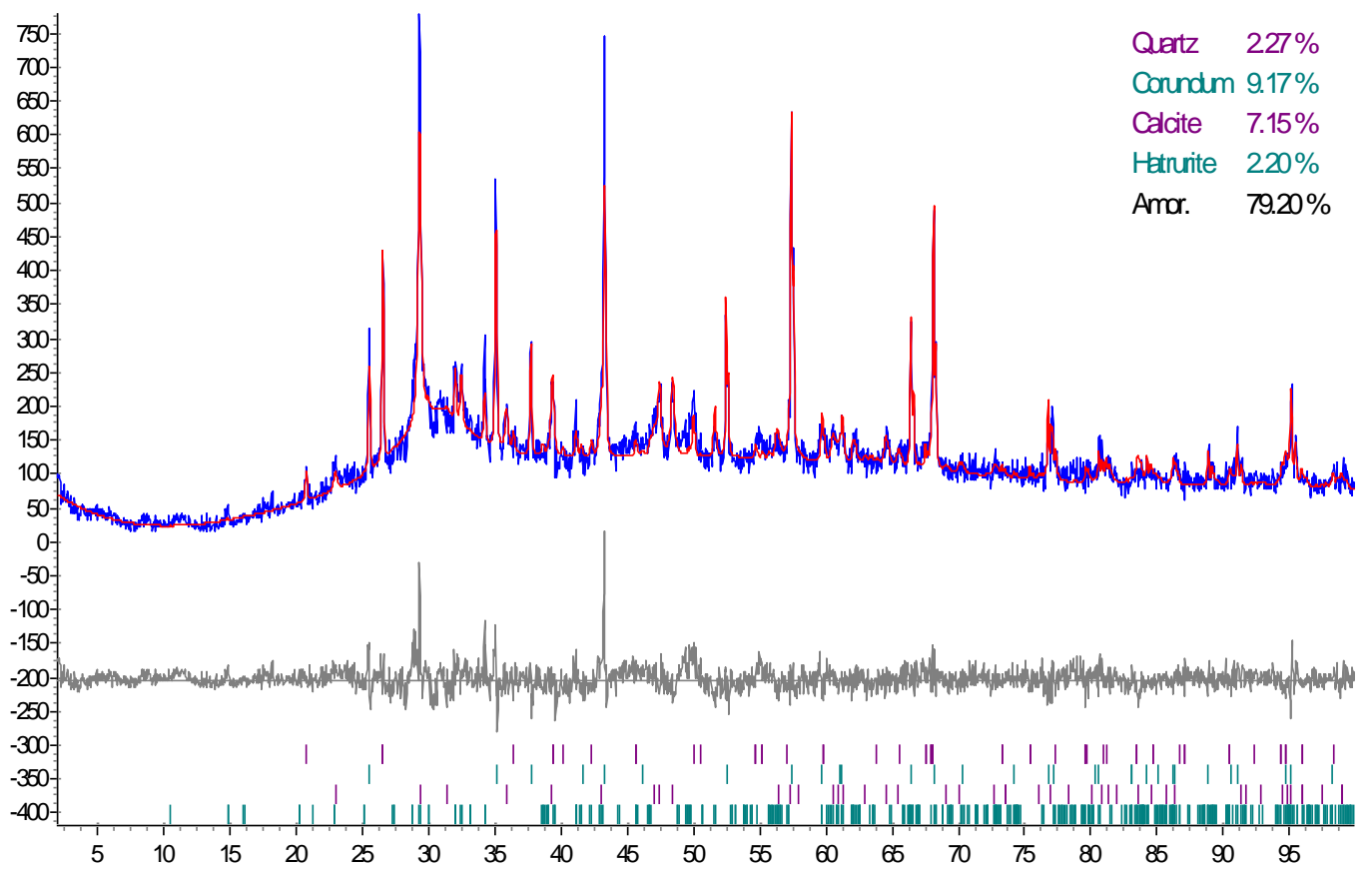

Figure 5.2. Phase Identification for Cast Stone Sample CS-11-S1-4-401. Corundum has been added as an internal standard. The TOPAS crystal structure fit and the residual are also shown. $($ Blue $=$ observed, red $=$ calculated, grey $=$ difference $)$. 


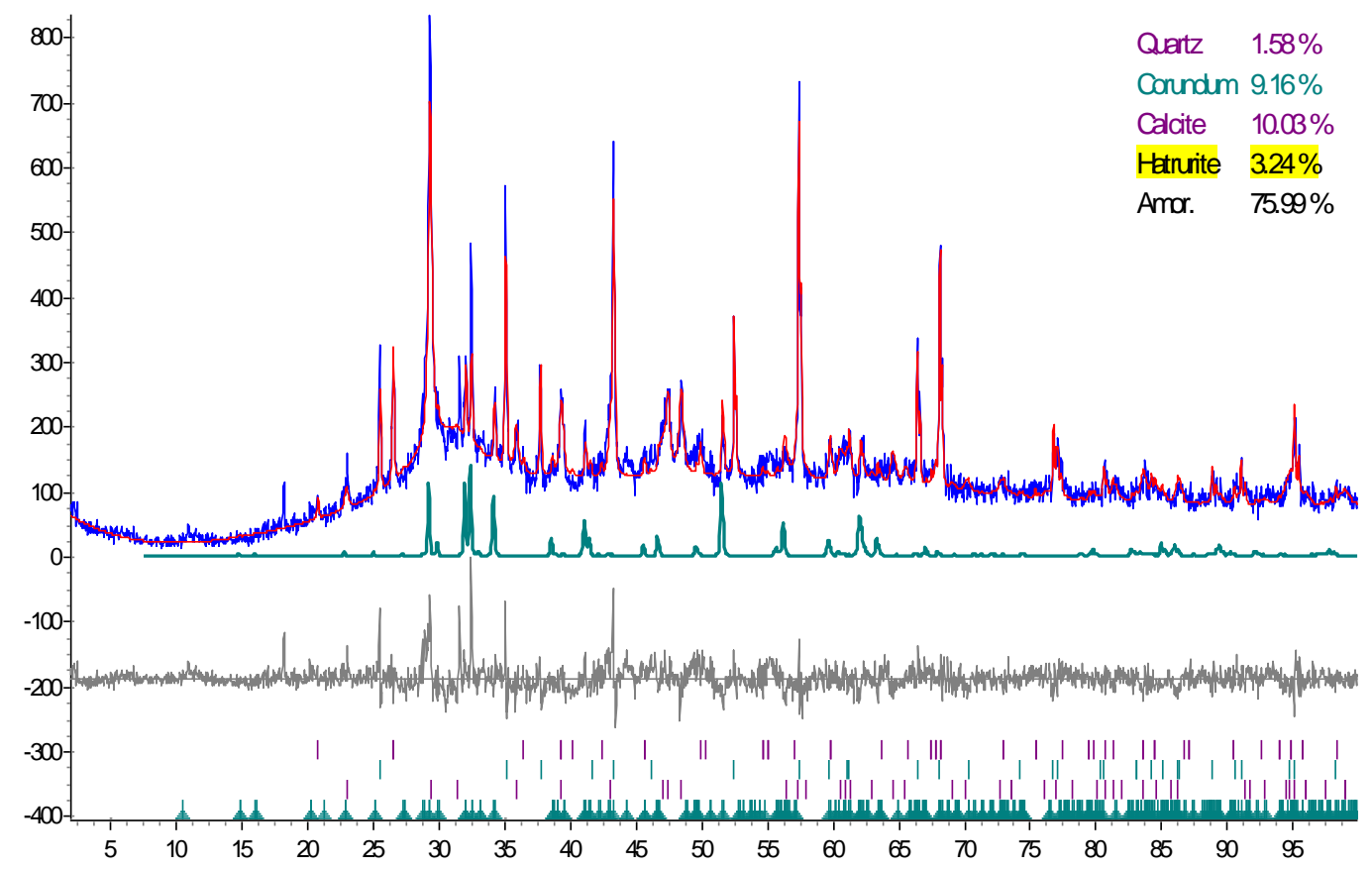

Figure 5.3. Phase Identification for Cast Stone Sample CS-11-S1-6-504. Corundum has been added as an internal standard. The TOPAS crystal structure fit and the residual are also shown. The simulated hatrurite diffraction pattern is shown in dark green to highlight the peak matches. (Blue $=$ observed, red $=$ calculated , grey $=$ difference $)$.

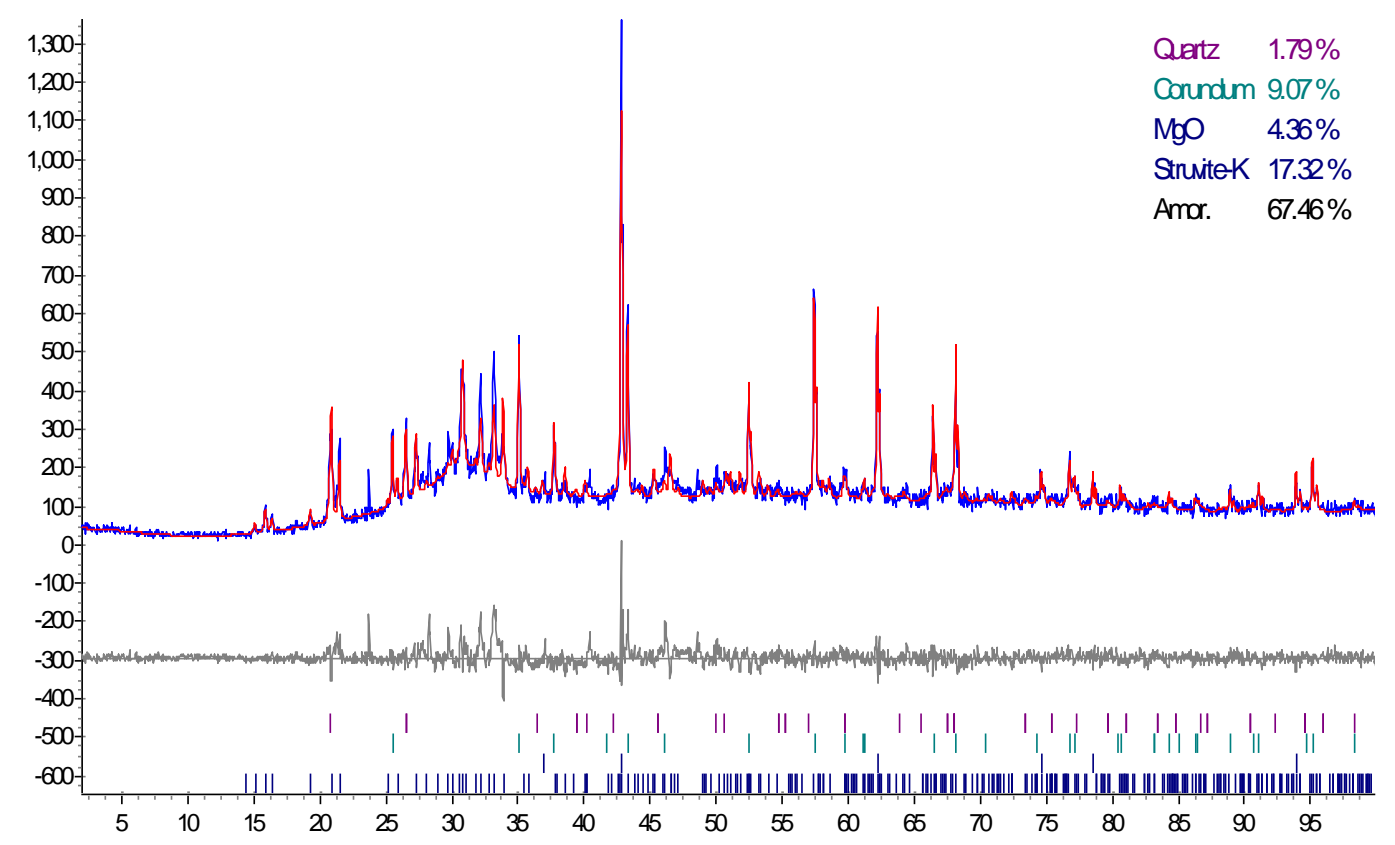

Figure 5.4. Phase Identification for Ceramicrete Sample CE-11-S1-2-10X. Corundum has been added as an internal standard. The TOPAS crystal structure fit and the residual are also shown. $($ Blue $=$ observed, red $=$ calculated , grey $=$ difference $)$. 


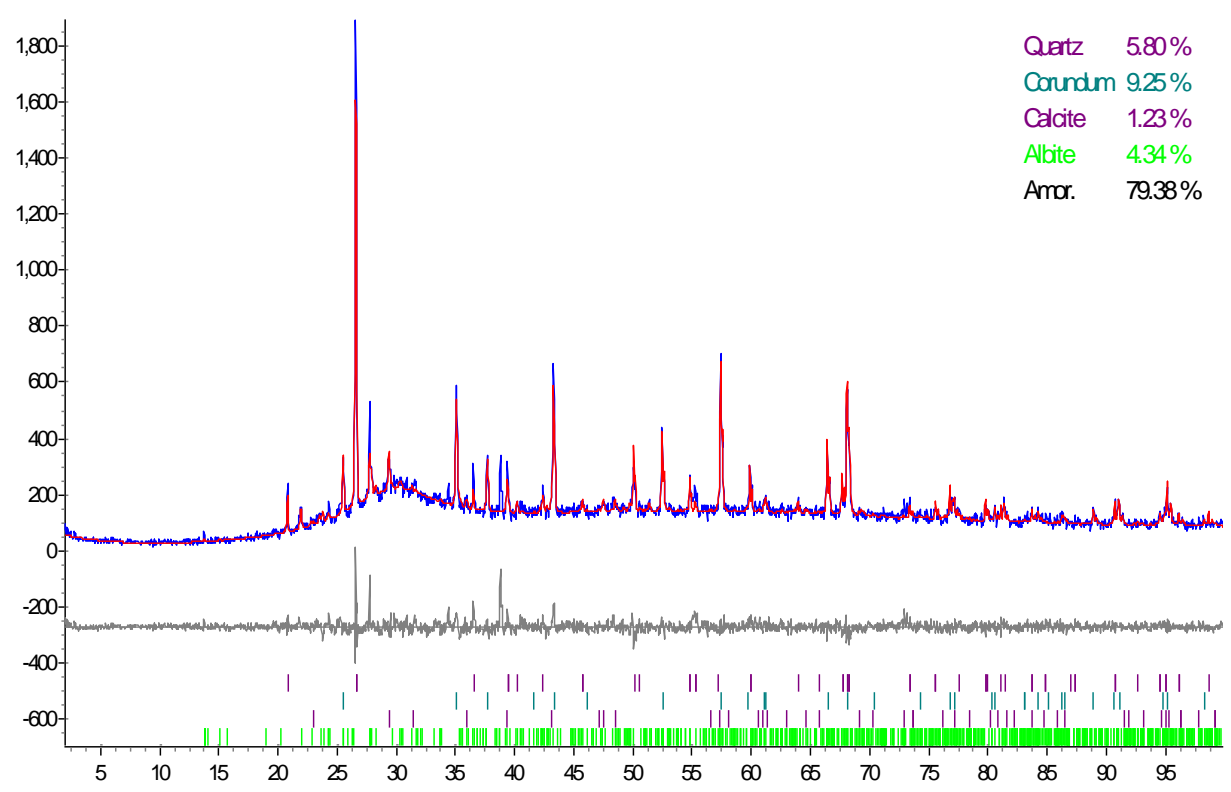

Figure 5.5. Phase Identification for DuraLith Sample GP-11-S1-6-310. Corundum has been added as an internal standard. The TOPAS crystal structure fit and the residual is also shown. (Blue $=$ observed, red $=$ calculated, and grey $=$ difference $)$.

\subsection{Scanning Electron Microscopy and Energy-Dispersive Spectroscopy}

Typical SEM images, maps of selected elements and energy-dispersive (ED) spectra for samples of Cast Stone, Ceramicrete, and DuraLith are shown in Figure 5.6 - Figure 5.8. The Cast Stone appears to consist of relatively dense matrix with a network of finely webbed cracks (Figure 5.6). The elemental maps and the ED spectrum of these waste forms confirm the identity of dominant elements as determined by the total chemical analysis of the specimens (Section 5.1).

The ED analysis and elemental maps indicated that the matrix of the Cast Stone consists mainly of Si, $\mathrm{Ca}, \mathrm{Na}, \mathrm{Al}$ and $\mathrm{Mg}$ with trace quantities of $\mathrm{Fe}, \mathrm{Mn}, \mathrm{Ti}, \mathrm{K}, \mathrm{S}$ and $\mathrm{Cl}$ (Figure 5.6).

The Ceramicrete consists of relatively porous matrix with wide interconnected cracks (Figure 5.7). The elemental maps and ED spectrum of Ceramicrete confirm that it is principally a potassium magnesium phosphate waste form. XRD analysis indicated that these three elements account for $\sim 25 \%$ of the crystalline component of the Ceramicrete matrix. The major elements in this waste form were identified to be $\mathrm{P}, \mathrm{K}, \mathrm{Mg}, \mathrm{Ca}$ and $\mathrm{Si}$ (Figure 5.7). Minor amounts of $\mathrm{Na}$ and $\mathrm{Al}$ and trace quantities of $\mathrm{S}$, $\mathrm{Cl}$, Ti and Fe were also detected in this monolith sample.

The SEM image of the DuraLith sample revealed a relatively dense matrix with an extensive network of fine and large cracks (Figure 5.8). Unmolded DuraLith monoliths exhibited impressions of entrained air bubbles. The SEM images also revealed a number of small-to-large impressions of air bubbles that were entrained in the interior of this sample of waste form. The major elements in this waste form were identified to be $\mathrm{Si}, \mathrm{Ca}, \mathrm{Al}, \mathrm{Na}$, and $\mathrm{K}$ (Figure 5.8). Minor amounts of $\mathrm{Mg}$ and trace quantities of $\mathrm{S}, \mathrm{Fe}, \mathrm{Ti}$, $\mathrm{P}$ and $\mathrm{Cl}$ were also detected in this monolith sample (Figure 5.8). The composition of DuraLith reflects the composition of major ingredients, namely silica fume, sand, blast furnace slag, metakaolin and alkalis used in the mix. 
Figure 5.6. SEM Image Elemental Maps and ED Spectrum of Cast Stone. Sample (CS-11-S1-6-503B5)
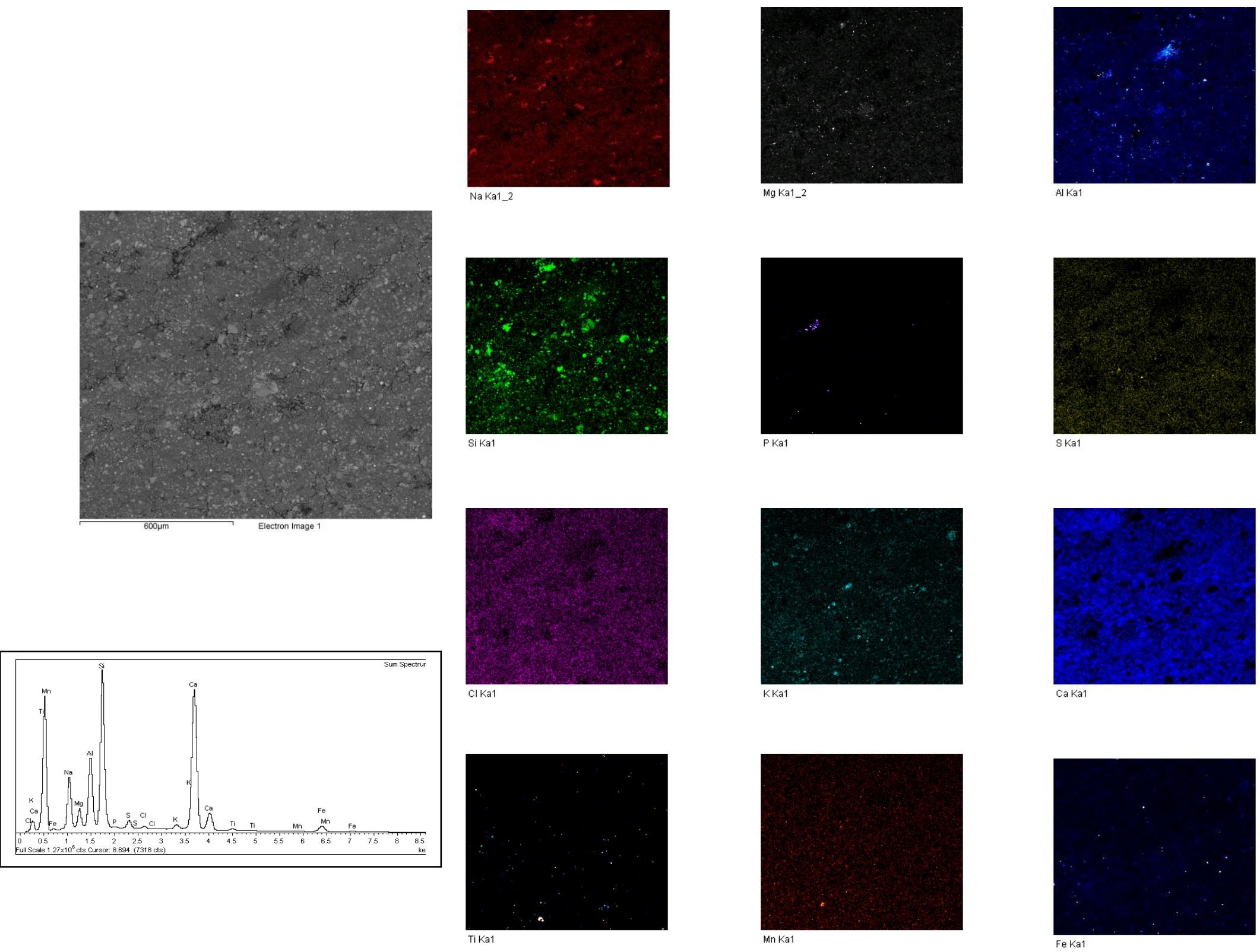
Figure 5.7. SEM Image, Elemental Maps and ED Spectrum of Ceramicrete Sample (CE-11-S1-2-10XB7)
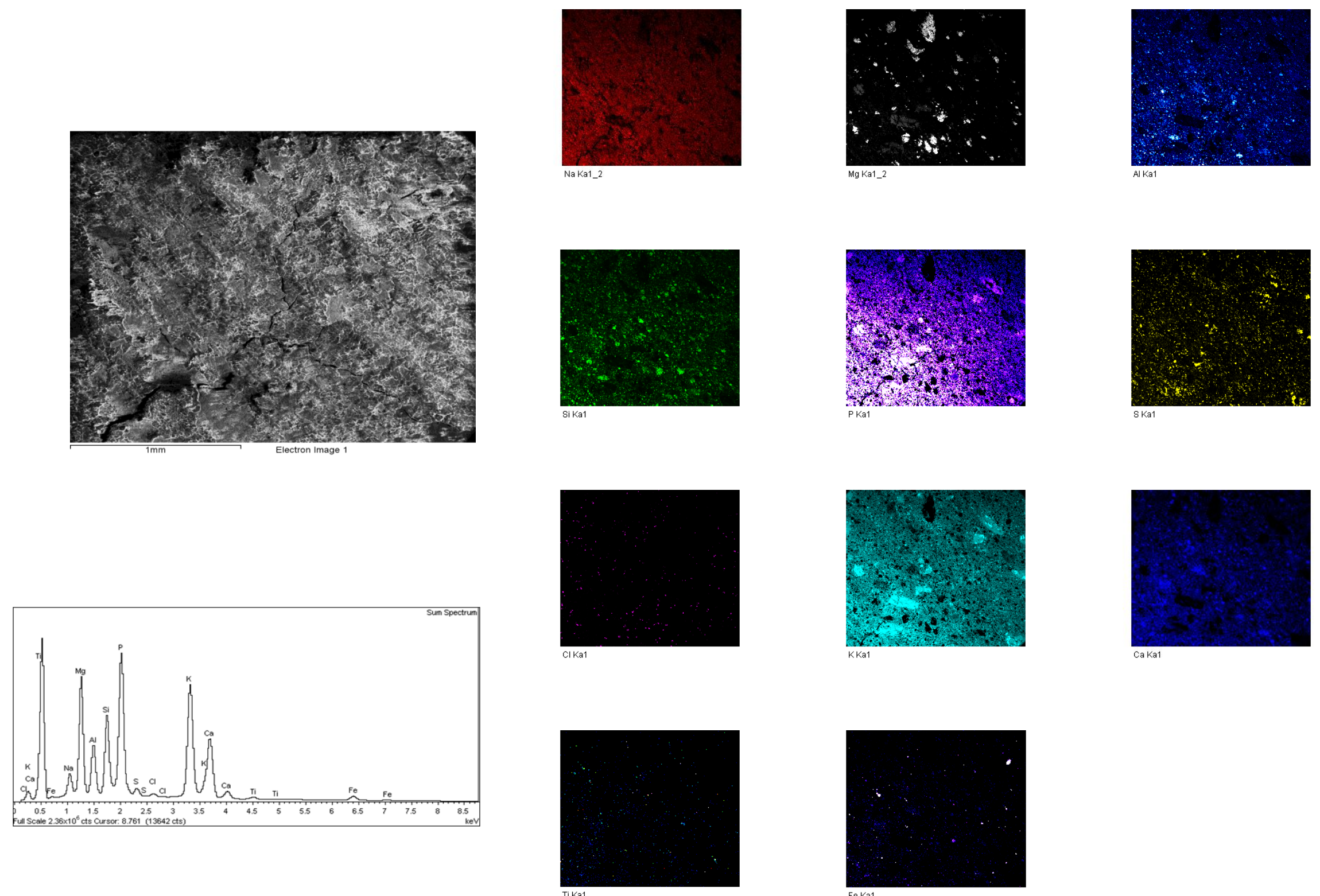
Figure 5.8. SEM Image, Elemental Maps, and ED Spectrum of DuraLith Sample (GP-11-S1-6-310B2)
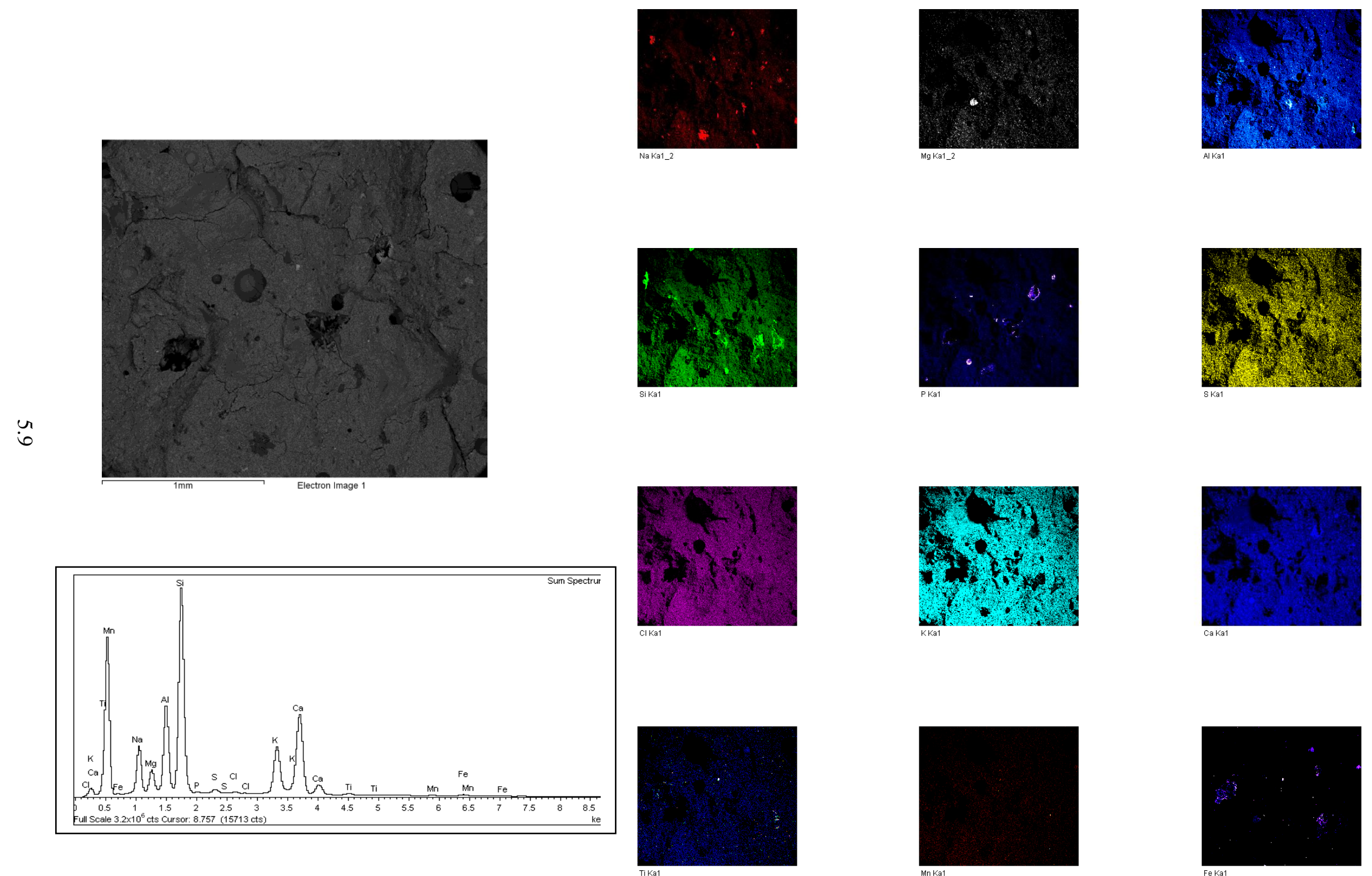


\subsection{Compressive Strength}

A compressive strength of $3.45 \mathrm{MPa}$ (500psi) has been set as the minimum compressive strength for the secondary waste forms. This is higher than the minimum compressive strength required by the IDF but is consistent with the NRC's Waste Form Technical Position for cement-based waste forms (NRC 1991). The compressive strengths of various secondary waste forms after 28 days of curing, thermal cycling, water immersion, and 90-day air curing are presented in Figure 5.9. The average compressive strengths for Cast Stone 2M, Ceramicrete, and DuraLith after 28 days of curing are 17.34, 6.81, and 23.29 MPa, respectively. The standard deviations of compressive strengths of Cast Stone 2M, Ceramicrete, and DuraLith are 10.20, 4.22, and 6.26 MPa, respectively. All the specimens except two of the Ceramicrete specimens passed the compressive strength requirement of $3.45 \mathrm{MPa}$ (500 psi). Two out of six Ceramicrete samples tested did not meet the minimum strength requirement of $3.45 \mathrm{MPa}$, indicating a failure rate of $\sim 33 \%$. Such low compressive strength may perhaps be attributable to cracks typically observed in 28-day cured Ceramicrete specimens (Figure 5.10).

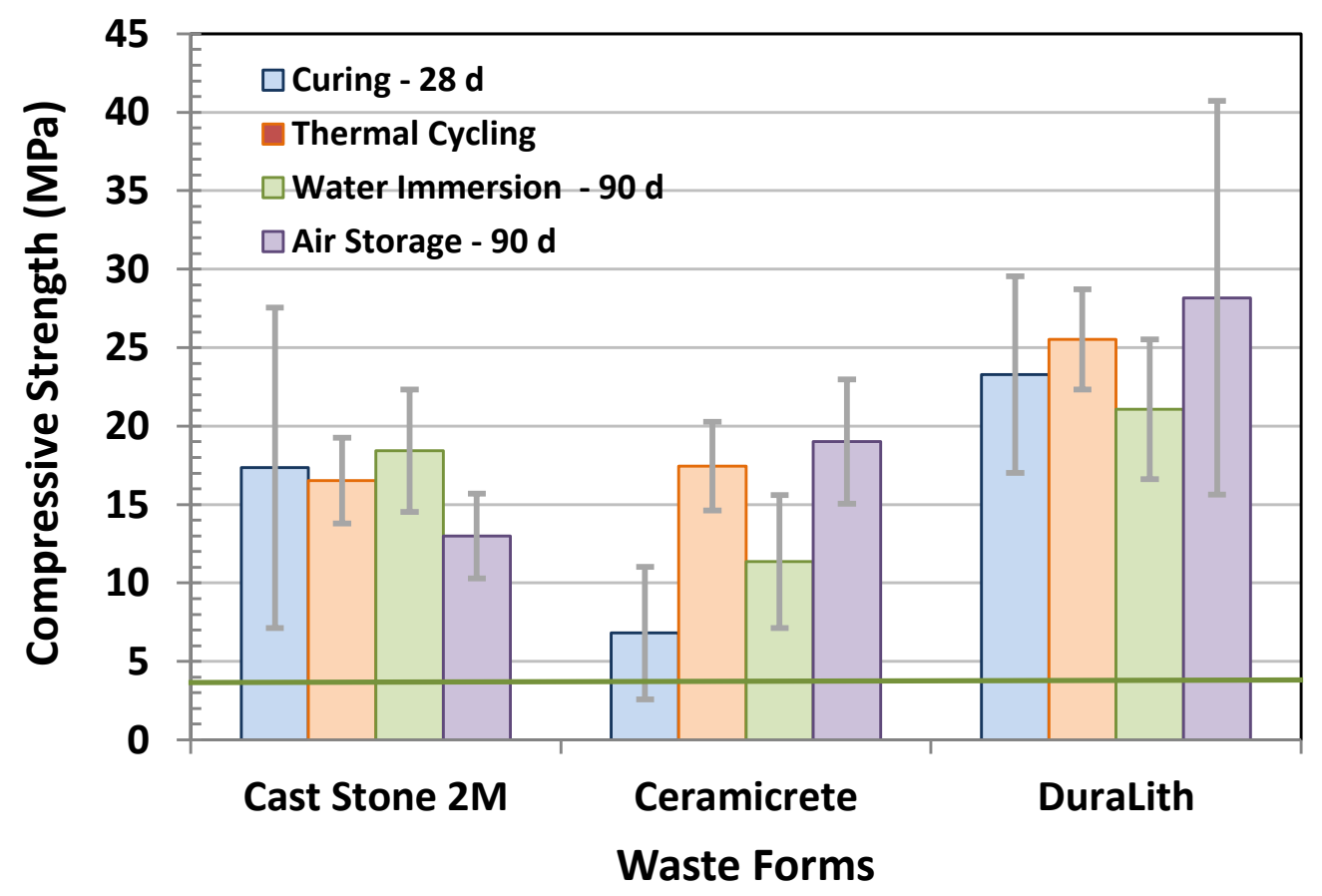

Figure 5.9. Compressive Strengths of Secondary Waste Forms after Various Treatments. The horizontal green line indicates the minimum compressive strength requirement of $3.45 \mathrm{MPa}$. 


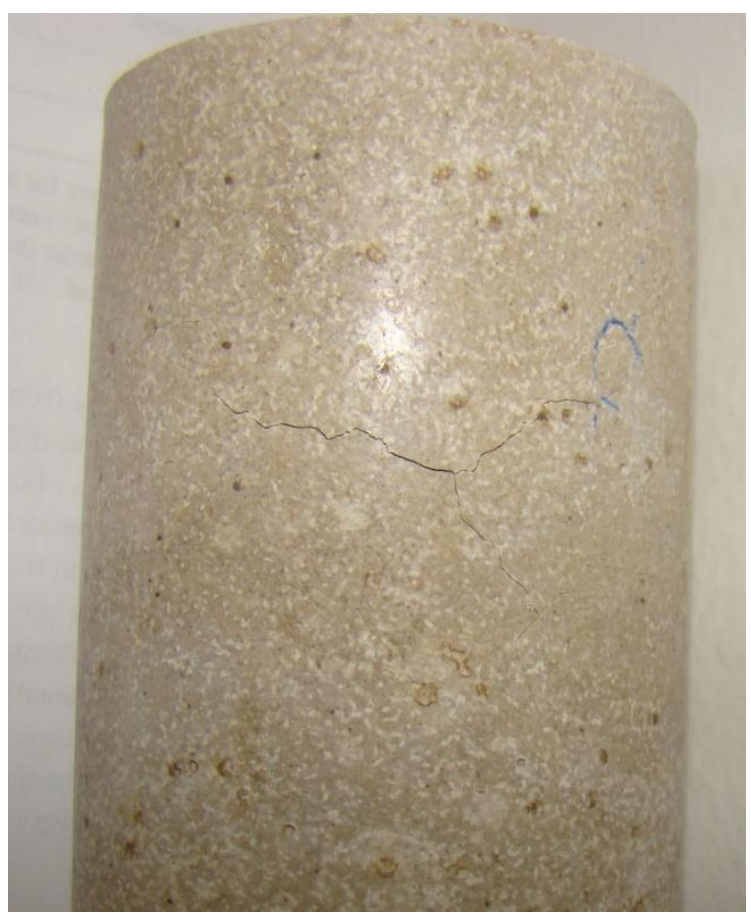

Figure 5.10. Preexisting Crack Observed in Ceramicrete Specimen

The Fracture patterns of Cast Stone, Ceramicrete, and DuraLith specimens after compressive strength tests are shown in Figure 5.11. The specimens showed failure parallel to the loading axis; this was the typical failure mode for all three waste forms.

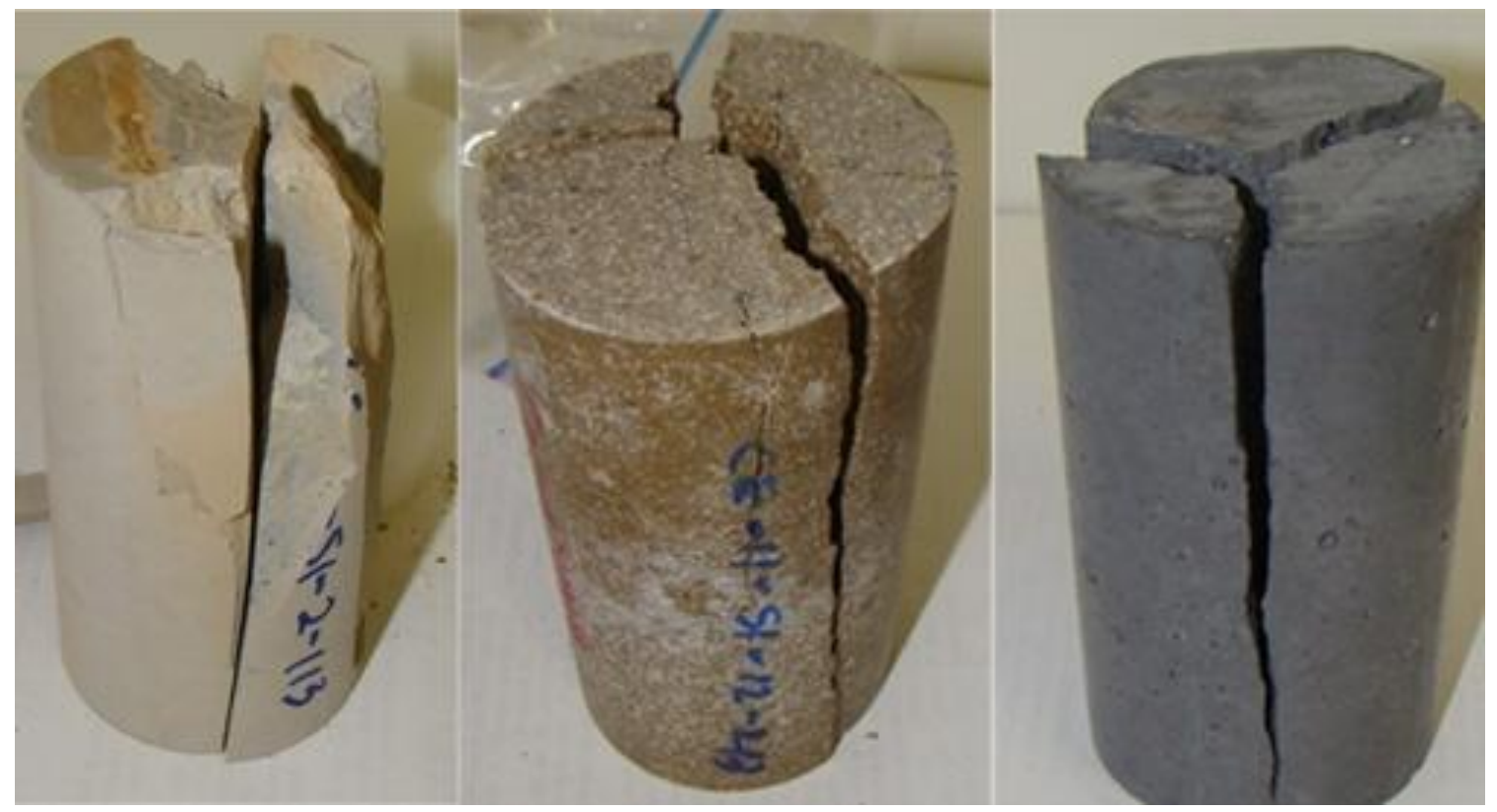

Figure 5.11. Fracture Patterns of Cast Stone, Ceramicrete, and DuraLith (picture taken after compressive strength measurement on 28-day cured samples) 
The compressive strengths of Cast Stone 2M, Ceramicrete, and DuraLith that were subjected to thermal cycling are also presented in Figure 5.9. The thermal cycling between $-40{ }^{\circ} \mathrm{C}$ and $60{ }^{\circ} \mathrm{C}$ represents severe environmental conditions that could easily damage the specimens. During heating and cooling cycles, any free water in the specimens would dry or freeze, resulting in freeze-thaw cracking of specimens, which typically results in reductions of compressive strength. The pictures of specimens after thermal cycling are shown in Figure 5.12. Ceramicrete specimens had preexisting visible cracks after 28-day curing (Figure 5.10) that became more visible after thermal curing. However, thermal cycling apparently increased the compressive strength of Ceramicrete, which indicated that the visible surface cracks had no bearing on the compressive strengths of these specimens. Similarly, the Cast Stone specimens also exhibited very fine networks of cracks after thermal cycling, due perhaps to drying and or carbonation of the specimens. However, these very fine cracks did not seem to affect the compressive strength of these specimens. The DuraLith specimens after thermal cycling never showed any visible cracks.

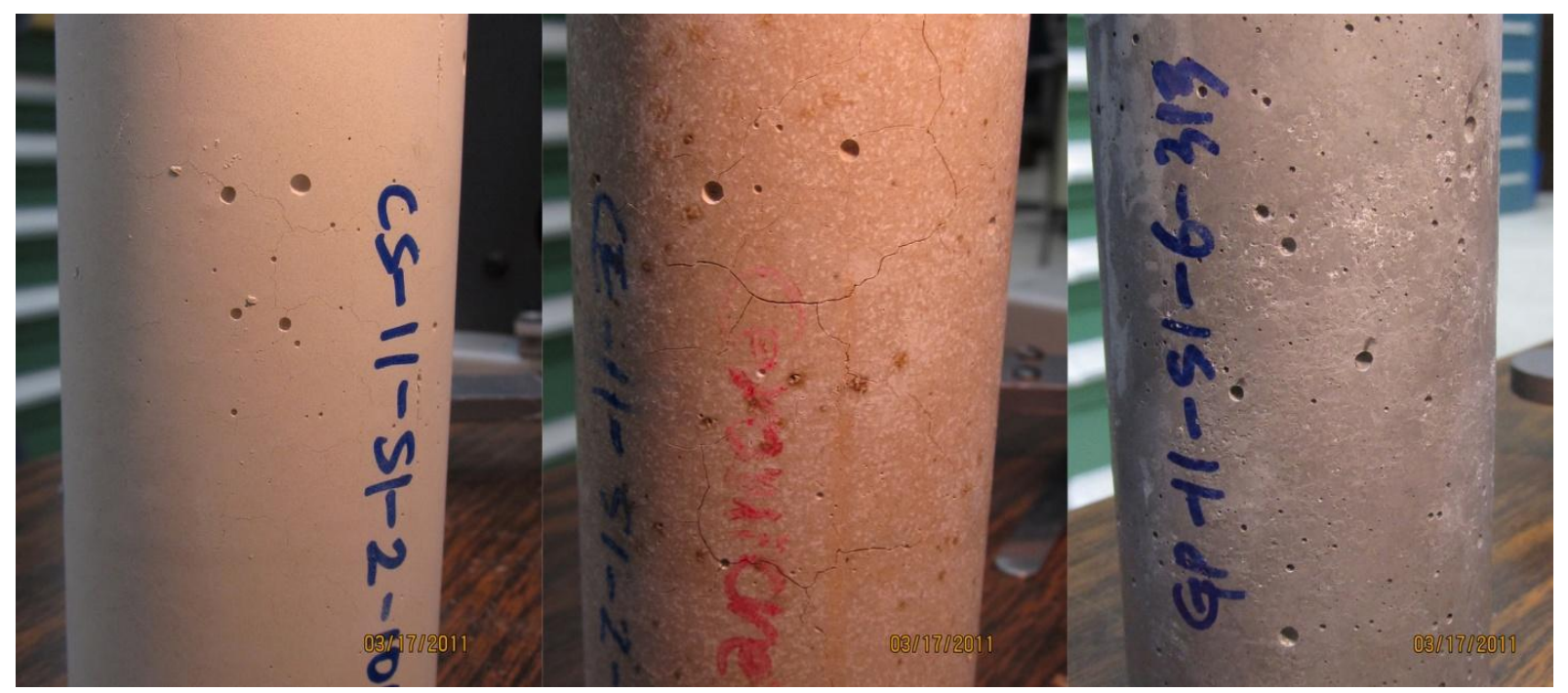

Figure 5.12. Patterns of Surface Cracks Observed after Thermal Cycling. From left to right: Cast Stone, Ceramicrete, and DuraLith monoliths. DuraLith does not show surface cracking.

The compressive strengths of Cast Stone 2M, Ceramicrete, and DuraLith that were first immersed in DIW for 90 days before compressive strength testing are presented in Figure 5.9. For comparison, the compressive strengths of Cast Stone 2M, Ceramicrete, and DuraLith that were stored in ambient air for 90 days are also presented in Figure 5.9. All the specimens tested passed the compressive strength requirement of $3.45 \mathrm{MPa}$. Air drying for 90 days prior to performing compressive strength testing did appear to result in lower strengths for the Cast Stone in comparison with any other treatment, but for the other two waste forms air drying actually resulted in the highest average compressive strengths measured or at least showed no potentially deleterious effects. However, as mentioned all but two of the Ceramicrete monoliths passed the $3.45 \mathrm{MPa}$ criteria.

The DuraLith specimens showed surface cracking after the completion of the 90-day waterimmersion test (Figure 5.13). However, these specimens had significantly higher compressive strengths than the required compressive strength of $3.45 \mathrm{MPa}$. 


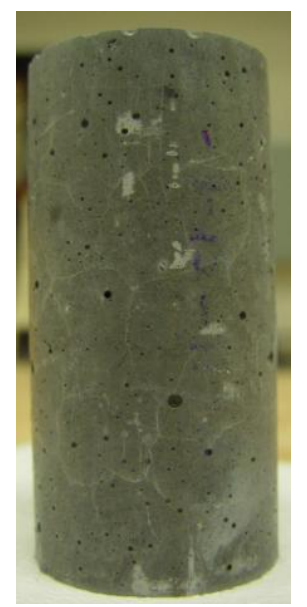

Figure 5.13. Surface Crack Patterns of DuraLith Specimen (after 90 days of water immersion)

The compressive strengths of 2-M, 4-M, and 6-M Na Cast Stone specimens cured for 28 days are presented in Figure 5.14. The average compressive strengths of Cast Stone 2-M, 4-M and 6-M specimens were 17.34, 8.30 and 12.58 MPa, respectively. All the Cast Stone specimens passed the compressive strength requirement of $3.45 \mathrm{MPa}$.

The compressive strength of cured specimens may be affected by cracking induced by thermal cycling and/or increasing proportions of crystalline phases in the waste forms. Thermal cycling, longterm air curing, and water immersion affect the physical and chemical characteristics of waste forms, thus affecting their compressive strengths. Depending on the formulation of waste forms, these treatments may either increase or decrease the compressive strengths as compared to the baseline compressive strength after curing for 28 days. These studies indicate that these waste forms did not show any degradation in compressive strength following various curing regimens. However, it is impossible to predict the longterm behavior of the engineering-scale monoliths

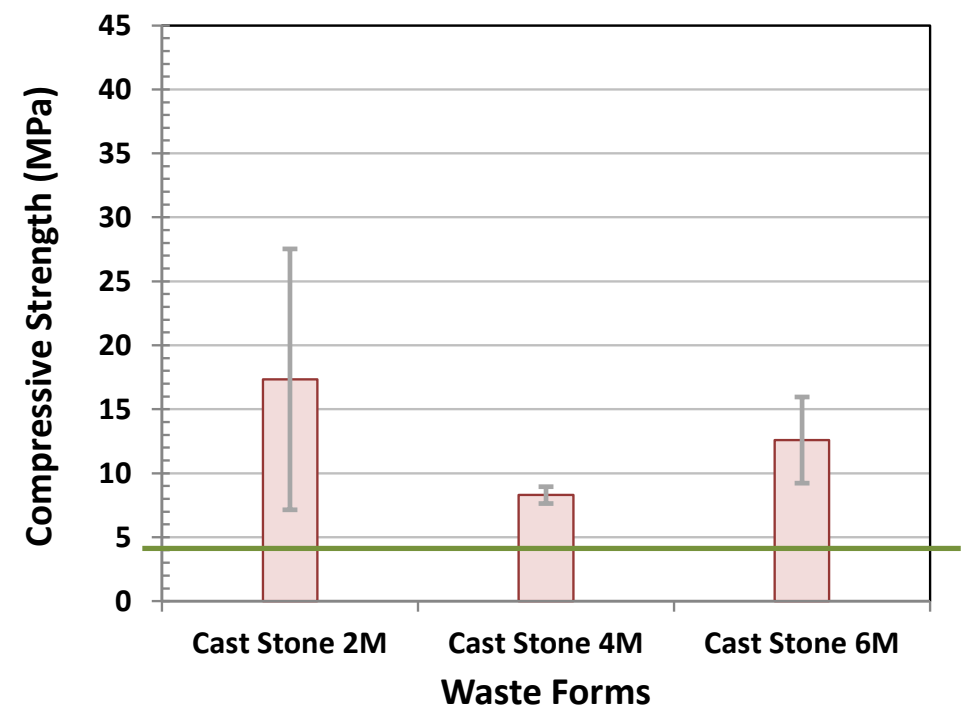

Figure 5.14. Compressive Strength of Cast Stone Specimens According to the Na Concentration Levels. The horizontal green line indicates the minimum compressive strength requirement of $3.45 \mathrm{MPa}$. 


\subsection{Free Liquids}

No free liquid was observed after the waste form specimens were cast or for the duration of all curing times. Therefore, there was no need to conduct the paint filter test.

\subsection{Diffusivity Leach Tests}

The NRC, in its Waste Form Technical Position, provides recommendations and guidance regarding methods to demonstrate waste stability for land disposal of radioactive waste. Included is a recommendation to conduct leach tests using the ANS 16.1 method. The resulting leachability index (LI) should be greater than 6.0. For Hanford secondary wastes, the LI $>6.0$ applies to sodium leached from

the waste form. For ${ }^{99} \mathrm{Tc}$ and ${ }^{129} \mathrm{I}$, higher targets of LI $>9$ and LI $>11$ respectively have been set based on early waste-disposal risk and performance assessment analyses. These targets need to be validated and verified based on more recent and future IDF performance assessments. The results of ANS 16.1, ASTM C1308 and EPA 1315 diffusivity leach tests are presented in the following sections. All discussions related to diffusivity resulting from ANS 16.1 and EPA 1315 tests are intervallic diffusivity values, whereas the results of the ASTM C1308 are discussed on the basis of cumulative diffusivity values. The iodine concentrations in Ceramicrete were below detection limits $(<1.34 \mu \mathrm{g} / \mathrm{g}$, Table 4.1) therefore, all iodine diffusivity calculations for this waste form were based on the value calculated from the simulant input of iodine $(1.24 \mu \mathrm{g} / \mathrm{g})$ into the Ceramicrete mix.

\subsubsection{ANSI/ANS 16.1 Leach Test}

The calculated diffusivities and LIs for Tc, Re, I and Na are presented in the following sections. The results of the ANSI/ANS 16.1 leach tests on Cast Stone 2M, Ceramicrete and DuraLith are listed in Table 5.3 - Table 5.6, and the diffusivities for the elements of interest, namely Tc, Re, I and Na, as functions of sampling time are also shown graphically in Figure 5.15 - Figure 5.18. The data indicated good reproducibility for measurements made on duplicate monoliths of each waste form.

\subsubsection{Technetium Diffusivity}

The diffusivity data for technetium indicated that both Cast Stone 2M and DuraLith experienced rapid declines in leachability of technetium after one to two days (Figure 5.15). The diffusivities of both waste forms declined from the initial values of $\sim 5 \times 10^{-9} \mathrm{~cm}^{2} / \mathrm{s}$ to $\leq 1 \times 10^{-10} \mathrm{~cm}^{2} / \mathrm{s}$ after the first two days. At the end of 90 days both these waste forms yielded diffusivities that ranged from $\sim 2 \times 10^{-12} \mathrm{~cm}^{2} / \mathrm{s}$ for Cast Stone $2 \mathrm{M}$ to $\sim 5 \times 10^{-12} \mathrm{~cm}^{2} / \mathrm{s}$ for DuraLith.

Comparatively, the Ceramicrete showed a relatively steady release of technetium throughout the 90day experimental period. Both Ceramicrete monoliths exhibited the same technetium release behavior, which indicates that this phenomenon was inherent to this waste form. Throughout the experimental period, the Tc diffusivities on average ranged from $\sim 1.5 \times 10^{-10} \mathrm{~cm}^{2} / \mathrm{s}$ to $\sim 5 \times 10^{-10} \mathrm{~cm}^{2} / \mathrm{s}$. 
The calculated average technetium leaching indices are 10.1 for Cast Stone 2M, 9.6 for Ceramicrete, and 10.5 for DuraLith respectively (Table 5.3). These values exceed the regulatory minimum LI of 9 for technetium.

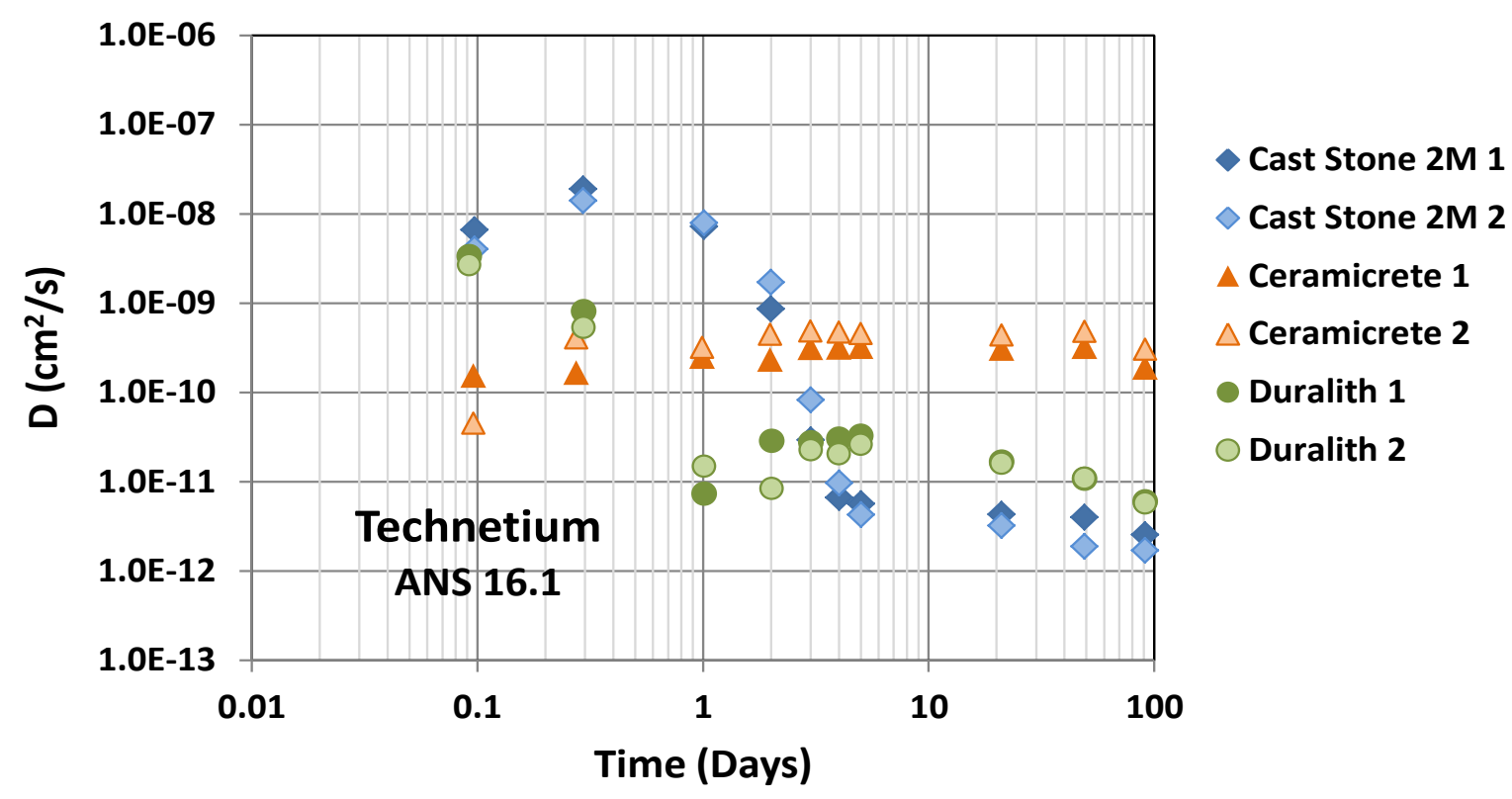

Figure 5.15. Technetium Diffusivity (ANS 16.1) of Cast Stone, Ceramicrete and DuraLith Monoliths

\subsubsection{Rhenium Diffusivity}

The Re diffusivities and LIs determined from the ANS 16.1 tests are tabulated (Table 5.4) and the diffusivities as functions of time are also graphically displayed in Figure 5.16. Both Cast Stone 2M and DuraLith showed steadily declining diffusivities for Re after one day, whereas diffusivity in Ceramicrete did not show any decline until leaching had proceeded for $\sim 20$ days. During the first day, Re diffusivities in Cast Stone and DuraLith ranged from $\sim 6 \times 10^{-8} \mathrm{~cm}^{2} / \mathrm{s}$ to $\sim 1 \times 10^{-7} \mathrm{~cm}^{2} / \mathrm{s}$, and at the conclusion of 90 days of leaching the Re diffusivity of Cast Stone had declined by about 4 orders of magnitude to $\sim 6.5 \times 10^{-12} \mathrm{~cm}^{2} / \mathrm{s}$. In comparison, the Ceramicrete and DuraLith samples had average Re diffusivities of $3 \times 10^{-9} \mathrm{~cm}^{2} / \mathrm{s}$ and $\sim 8 \times 10^{-9} \mathrm{~cm}^{2} / \mathrm{s}$ respectively after 90 days of leach testing. 


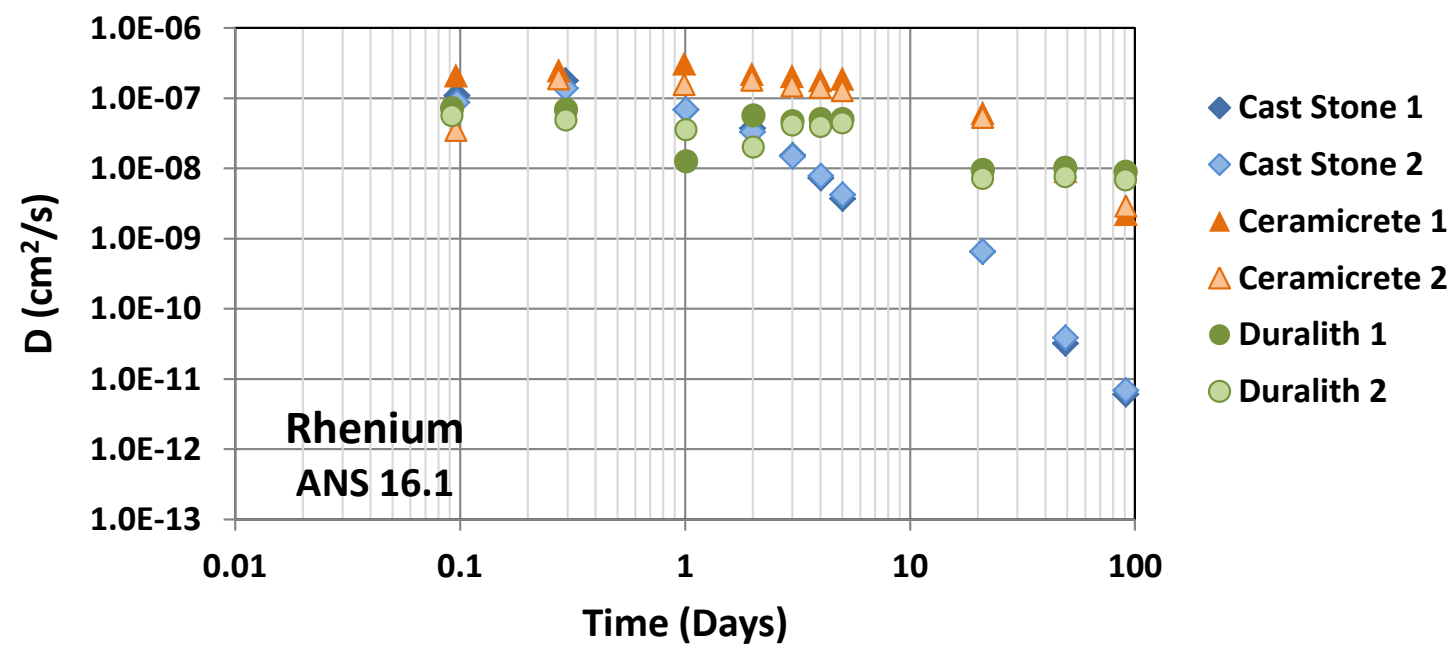

Figure 5.16. Rhenium Diffusivity (ANS 16.1) of Cast Stone, Ceramicrete and DuraLith Monoliths

The average LI values for Re were calculated to be 8.4 for Cast Stone 2M, 7.1 for Ceramicrete, and 7.6 for DuraLith, respectively (Table 5.4). None of the waste forms exceed the target LI $>9$ for technetium based on rhenium as a surrogate for technetium. This poses a significant issue on the use of rhenium as a surrogate for technetium in low temperature secondary waste stabilization studies. Detailed discussion of this issue is provided in Section 5.5.4.

\subsubsection{3 lodine Diffusivity}

The iodine (added as iodide) diffusivities and LIs from the ANS 16.1 leach tests conducted on Cast Stone 2M, Ceramicrete and DuraLith samples are listed in Table 5.5 and the plot of diffusivity data is shown in Figure 5.17. Cast Stone $2 \mathrm{M}$ at the first three sampling times exhibited leach-interval iodine diffusivities that ranged from $\sim 1 \times 10^{-7} \mathrm{~cm}^{2} / \mathrm{s}$ to $\sim 3 \times 10^{-7} \mathrm{~cm}^{2} / \mathrm{s}$, which at the end of 90 days had declined by about two orders of magnitude to an interval-averaged value of $<2 \times 10^{-9} \mathrm{~cm}^{2} / \mathrm{s}$. In comparison, the DuraLith samples showed increasing diffusivities as a function of time and at the end of the 90-day leaching period had iodine diffusivities $\left(\sim 1 \times 10^{-8} \mathrm{~cm}^{2} / \mathrm{s}\right)$ that were an order of magnitude higher than the initial diffusivity of $\sim 6 \times 10^{-9} \mathrm{~cm}^{2} / \mathrm{s}$ (Figure 5.17 , Table 5.5).

For the Ceramicrete leachates, the concentrations of iodine were below detection limits; therefore, only the upper limit of diffusivities could be estimated.

The calculated average values of iodine LIs were 7.6 for Cast Stone, $>8.4$ for Ceramicrete and 7.8 for DuraLith (Table 5.5). These values are significantly below the target values (LI > 11) for iodine, suggesting that none of the waste forms retains iodine sufficiently. 


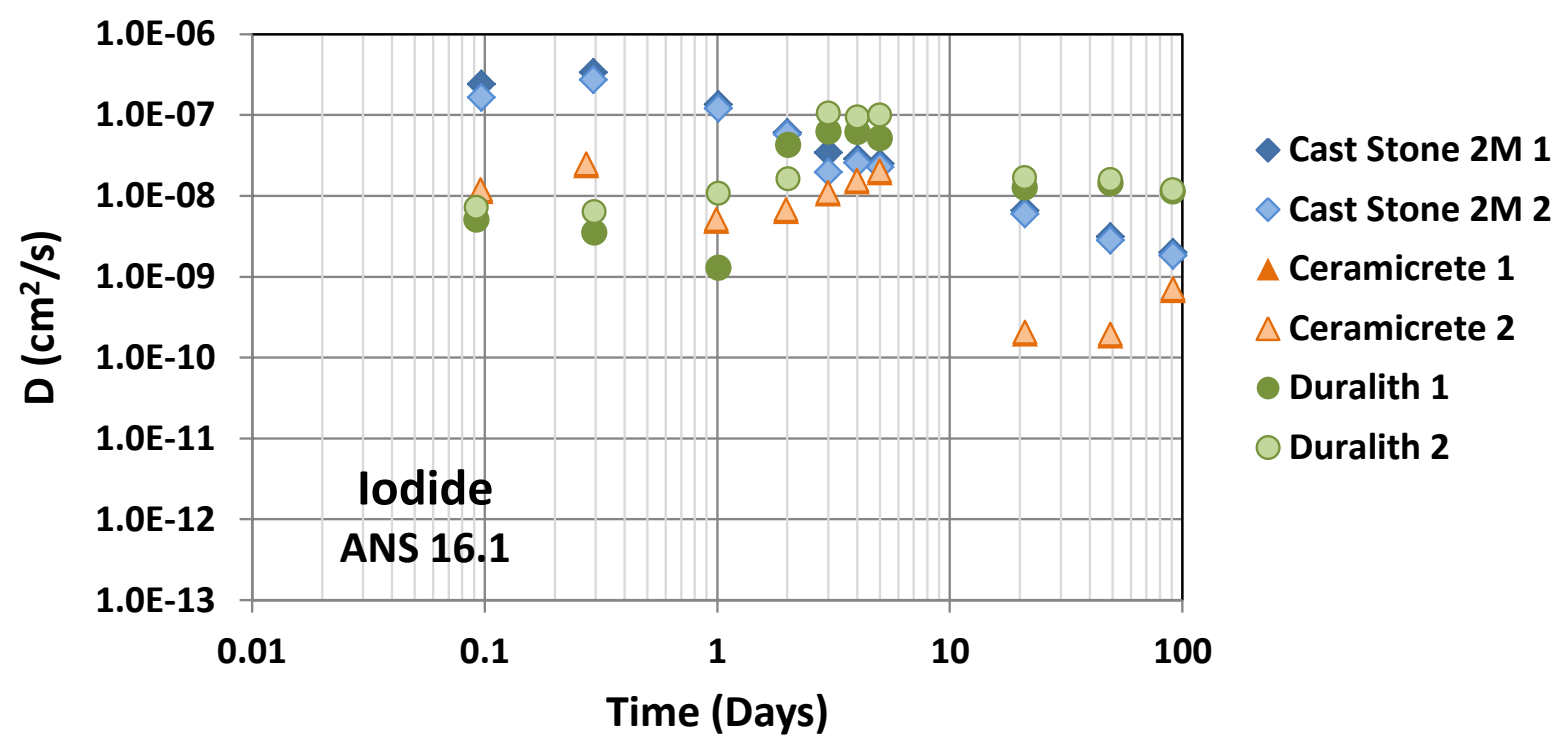

Figure 5.17. Iodine Diffusivity (ANS 16.1) of Cast Stone, Ceramicrete and DuraLith Monoliths

\subsubsection{Sodium Diffusivity}

The sodium diffusivities and LIs from the ANS 16.1 leach tests conducted on Cast Stone 2M, Ceramicrete and DuraLith samples are listed in Table 5.6 and the plot of diffusivity data is shown in Figure 5.18. During the first seven sampling times, all three waste forms exhibited average diffusivities of $\sim 1 \times 10^{-8} \mathrm{~cm}^{2} / \mathrm{s}$. Subsequent sampling times indicated a rapid decline in sodium diffusivity from Cast Stone specimens and at the end of the 90-day period the diffusivity was about two orders of magnitude lower $\left(\sim 8 \times 10^{-11} \mathrm{~cm}^{2} / \mathrm{s}\right)$ than the initial diffusivities. In comparison, Ceramicrete at the end of the experimental period showed 3 to 4 times the reduction in sodium diffusivity, whereas DuraLith specimens at the end of the 90-day leaching period showed about an order of magnitude reduction in sodium diffusivities compared to the beginning of the leach tests (Figure 5.18, Table 5.6)

The calculated average values of sodium leaching LIs are 8.5 for Cast Stone 2M, 8.2 for Ceramicrete and 8.1 for DuraLith (Table 5.6). These values are better than the target (LI > 6.0) for sodium suggesting all three waste forms meet the IDF required value. 


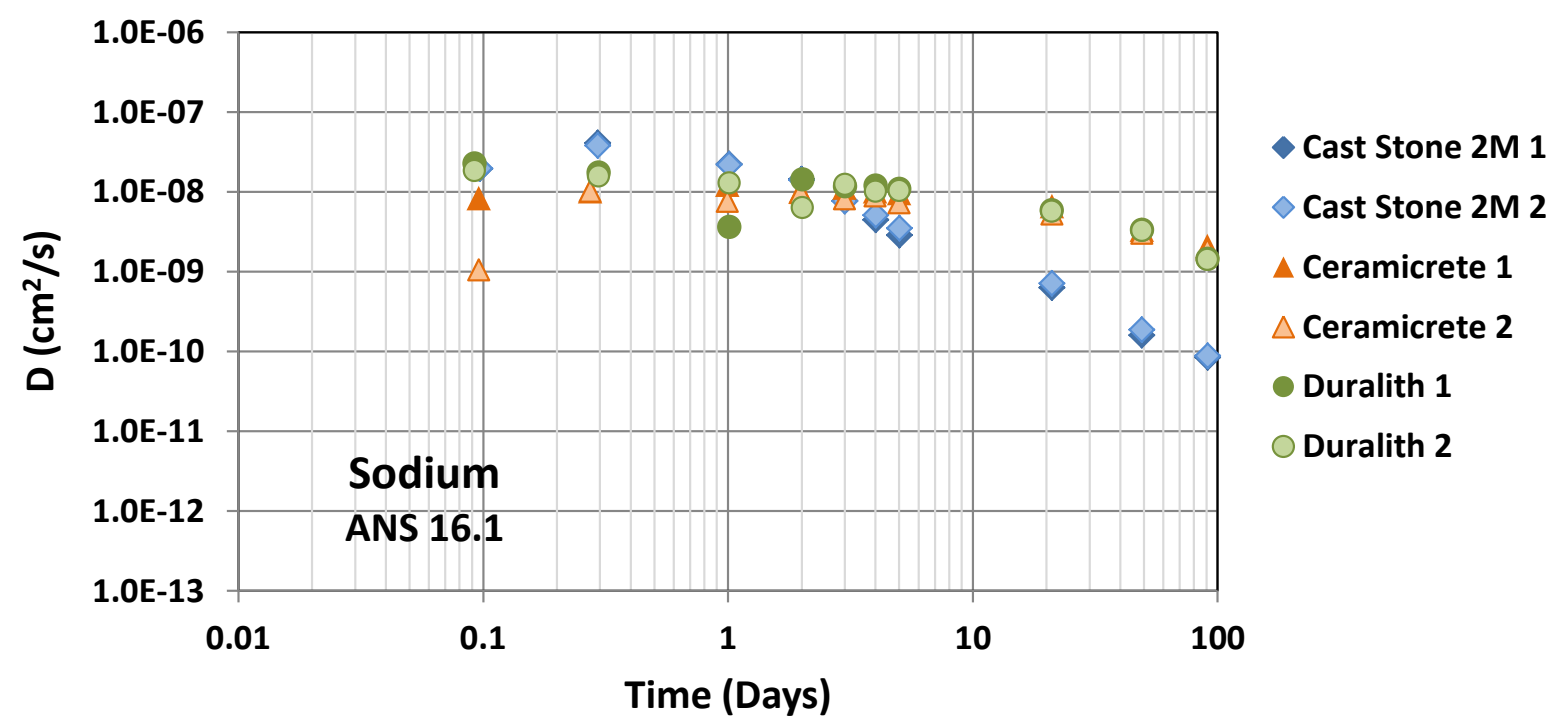

Figure 5.18. Sodium Diffusivity (ANS 16.1) of Cast Stone, Ceramicrete and DuraLith Monoliths 
Table 5.3. ANS 16.1 Leach Test - Technetium Diffusivity and Leaching Indices of Cast Stone, Ceramicrete and DuraLith Monoliths

\begin{tabular}{|c|c|c|c|c|c|c|c|c|c|c|c|c|c|c|}
\hline \multicolumn{5}{|c|}{ Cast Stone 2M } & \multicolumn{5}{|c|}{ Ceramicrete } & \multicolumn{5}{|c|}{ DuraLith } \\
\hline $\begin{array}{c}\text { Sampling } \\
\text { Days }\end{array}$ & $\begin{array}{c}\text { Specimen } 1 \\
\mathrm{D}\left(\mathrm{cm}^{2} / \mathrm{s}\right)\end{array}$ & LI & $\begin{array}{l}\text { Specimen } 2 \\
\mathrm{D}\left(\mathrm{cm}^{2} / \mathrm{s}\right)\end{array}$ & LI & $\begin{array}{c}\text { Sampling } \\
\text { Days }\end{array}$ & $\begin{array}{c}\text { Specimen } 1 \\
\mathrm{D}\left(\mathrm{cm}^{2} / \mathrm{s}\right)\end{array}$ & LI & $\begin{array}{c}\text { Specimen } 2 \\
\mathrm{D}\left(\mathrm{cm}^{2} / \mathrm{s}\right)\end{array}$ & LI & $\begin{array}{c}\text { Sampling } \\
\text { Days }\end{array}$ & $\begin{array}{c}\text { Specimen } 1 \\
\mathrm{D}\left(\mathrm{cm}^{2} / \mathrm{s}\right)\end{array}$ & LI & $\begin{array}{c}\text { Specimen } 2 \\
\mathrm{D}\left(\mathrm{cm}^{2} / \mathrm{s}\right)\end{array}$ & LI \\
\hline 0.097 & $6.61 \mathrm{E}-09$ & 8.2 & $4.01 \mathrm{E}-09$ & 8.4 & 0.096 & $1.54 \mathrm{E}-10$ & 9.8 & $4.52 \mathrm{E}-11$ & 10.3 & 0.092 & $3.37 \mathrm{E}-09$ & 8.5 & $2.69 \mathrm{E}-09$ & 8.6 \\
\hline 0.294 & $1.90 \mathrm{E}-08$ & 7.7 & $1.41 \mathrm{E}-08$ & 7.9 & 0.274 & $1.67 \mathrm{E}-10$ & 9.8 & $4.05 \mathrm{E}-10$ & 9.4 & 0.296 & $8.17 \mathrm{E}-10$ & 9.1 & $5.32 \mathrm{E}-10$ & 9.3 \\
\hline 1.012 & 7.22E-09 & 8.1 & 7.94E-09 & 8.1 & 0.993 & $2.52 \mathrm{E}-10$ & 9.6 & $3.19 \mathrm{E}-10$ & 9.5 & 1.010 & $7.36 \mathrm{E}-12$ & 11.1 & $1.49 \mathrm{E}-11$ & 10.8 \\
\hline 1.999 & $8.60 \mathrm{E}-10$ & 9.1 & $1.71 \mathrm{E}-09$ & 8.8 & 1.981 & $2.34 \mathrm{E}-10$ & 9.6 & $4.45 \mathrm{E}-10$ & 9.4 & 2.015 & $2.88 \mathrm{E}-11$ & 10.5 & $8.36 \mathrm{E}-12$ & 11.1 \\
\hline 3.009 & $2.93 \mathrm{E}-11$ & 10.5 & $8.27 \mathrm{E}-11$ & 10.1 & 2.990 & $3.17 \mathrm{E}-10$ & 9.5 & $4.86 \mathrm{E}-10$ & 9.3 & 3.001 & $2.77 \mathrm{E}-11$ & 10.6 & $2.27 \mathrm{E}-11$ & 10.6 \\
\hline 4.014 & $6.62 \mathrm{E}-12$ & 11.2 & $9.63 \mathrm{E}-12$ & 11.0 & 3.996 & $3.20 \mathrm{E}-10$ & 9.5 & $4.71 \mathrm{E}-10$ & 9.3 & 4.001 & $3.03 \mathrm{E}-11$ & 10.5 & $2.05 \mathrm{E}-11$ & 10.7 \\
\hline 5.017 & $5.64 \mathrm{E}-12$ & 11.2 & $4.25 \mathrm{E}-12$ & 11.4 & 4.999 & $3.25 \mathrm{E}-10$ & 9.5 & $4.54 \mathrm{E}-10$ & 9.3 & 5.001 & $3.28 \mathrm{E}-11$ & 10.5 & 2.61E-11 & 10.6 \\
\hline 21.061 & 4.32E-12 & 11.4 & $3.23 \mathrm{E}-12$ & 11.5 & 21.045 & $3.10 \mathrm{E}-10$ & 9.5 & $4.38 \mathrm{E}-10$ & 9.4 & 21.013 & $1.68 \mathrm{E}-11$ & 10.8 & $1.61 \mathrm{E}-11$ & 10.8 \\
\hline 49.066 & $4.01 \mathrm{E}-12$ & 11.4 & $1.88 \mathrm{E}-12$ & 11.7 & 49.045 & $3.25 \mathrm{E}-10$ & 9.5 & $4.83 \mathrm{E}-10$ & 9.3 & 49.019 & $1.08 \mathrm{E}-11$ & 11.0 & $1.09 \mathrm{E}-11$ & 11.0 \\
\hline 91.066 & $2.55 \mathrm{E}-12$ & 11.6 & $1.70 \mathrm{E}-12$ & 11.8 & 91.045 & $1.90 \mathrm{E}-10$ & 9.7 & $3.03 \mathrm{E}-10$ & 9.5 & 90.95 & $6.05 \mathrm{E}-12$ & 11.2 & $5.78 \mathrm{E}-12$ & 11.2 \\
\hline & Average LI & 10.0 & & 10.1 & & & 9.6 & & 9.5 & & & 10.4 & & 10.5 \\
\hline
\end{tabular}

Table 5.4. ANS 16.1 Leach Test - Rhenium Diffusivity and Leaching Indices of Cast Stone, Ceramicrete and DuraLith Monoliths

\begin{tabular}{|c|c|c|c|c|c|c|c|c|c|c|c|c|c|c|}
\hline \multicolumn{5}{|c|}{ Cast Stone 2M } & \multicolumn{5}{|c|}{ Ceramicrete } & \multicolumn{5}{|c|}{ DuraLith } \\
\hline $\begin{array}{l}\text { Sampling } \\
\text { Days }\end{array}$ & $\begin{array}{l}\text { Specimen } 1 \\
\mathrm{D}\left(\mathrm{cm}^{2} / \mathrm{s}\right)\end{array}$ & LI & $\begin{array}{c}\text { Specimen } 2 \\
\mathrm{D}\left(\mathrm{cm}^{2} / \mathrm{s}\right)\end{array}$ & LI & $\begin{array}{l}\text { Sampling } \\
\text { Days }\end{array}$ & $\begin{array}{l}\text { Specimen } 1 \\
\mathrm{D}\left(\mathrm{cm}^{2} / \mathrm{s}\right)\end{array}$ & LI & $\begin{array}{l}\text { Specimen } 2 \\
\mathrm{D}\left(\mathrm{cm}^{2} / \mathrm{s}\right)\end{array}$ & LI & $\begin{array}{l}\text { Sampling } \\
\text { Days }\end{array}$ & $\begin{array}{l}\text { Specimen } 1 \\
\mathrm{D}\left(\mathrm{cm}^{2} / \mathrm{s}\right)\end{array}$ & LI & $\begin{array}{l}\text { Specimen } 2 \\
\mathrm{D}\left(\mathrm{cm}^{2} / \mathrm{s}\right)\end{array}$ & LI \\
\hline 0.097 & $1.09 \mathrm{E}-07$ & 7.0 & $8.67 \mathrm{E}-08$ & 7.1 & 0.096 & $2.51 \mathrm{E}-07$ & 6.6 & $4.10 \mathrm{E}-08$ & 7.4 & 0.092 & $7.21 \mathrm{E}-08$ & 7.1 & $5.64 \mathrm{E}-08$ & 7.2 \\
\hline 0.294 & $1.78 \mathrm{E}-07$ & 6.7 & $1.39 \mathrm{E}-07$ & 6.9 & 0.274 & $2.95 \mathrm{E}-07$ & 6.5 & 2.23E-07 & 6.7 & 0.296 & $6.91 \mathrm{E}-08$ & 7.2 & 4.87E-08 & 7.3 \\
\hline 1.012 & $6.82 \mathrm{E}-08$ & 7.2 & $6.90 \mathrm{E}-08$ & 7.2 & 0.993 & $3.71 \mathrm{E}-07$ & 6.4 & $1.83 \mathrm{E}-07$ & 6.7 & 1.010 & $1.27 \mathrm{E}-08$ & 7.9 & $3.53 \mathrm{E}-08$ & 7.5 \\
\hline 1.999 & $3.72 \mathrm{E}-08$ & 7.4 & $3.31 \mathrm{E}-08$ & 7.5 & 1.981 & 2.61E-07 & 6.6 & $2.12 \mathrm{E}-07$ & 6.7 & 2.015 & 5.69E-08 & 7.2 & 2.01E-08 & 7.7 \\
\hline 3.009 & $1.53 \mathrm{E}-08$ & 7.8 & $1.48 \mathrm{E}-08$ & 7.8 & 2.990 & $2.43 \mathrm{E}-07$ & 6.6 & $1.76 \mathrm{E}-07$ & 6.8 & 3.001 & 4.71E-08 & 7.3 & 4.14E-08 & 7.4 \\
\hline 4.014 & 7.28E-09 & 8.1 & 7.83E-09 & 8.1 & 3.996 & $2.13 \mathrm{E}-07$ & 6.7 & $1.66 \mathrm{E}-07$ & 6.8 & 4.001 & 5.07E-08 & 7.3 & $3.95 \mathrm{E}-08$ & 7.4 \\
\hline 5.017 & $3.68 \mathrm{E}-09$ & 8.4 & 4.22E-09 & 8.4 & 4.999 & $2.24 \mathrm{E}-07$ & 6.7 & $1.51 \mathrm{E}-07$ & 6.8 & 5.001 & $5.07 \mathrm{E}-08$ & 7.3 & 4.46E-08 & 7.4 \\
\hline 21.061 & $6.44 \mathrm{E}-10$ & 9.2 & $6.58 \mathrm{E}-10$ & 9.2 & 21.045 & 7.24E-08 & 7.1 & $6.27 \mathrm{E}-08$ & 7.2 & 21.013 & $9.51 \mathrm{E}-09$ & 8.0 & 7.12E-09 & 8.1 \\
\hline 49.066 & $3.20 \mathrm{E}-11$ & 10.5 & $3.87 \mathrm{E}-11$ & 10.4 & 49.045 & $1.09 \mathrm{E}-08$ & 8.0 & $1.22 \mathrm{E}-08$ & 7.9 & 49.019 & $1.03 \mathrm{E}-08$ & 8.0 & $7.62 \mathrm{E}-09$ & 8.1 \\
\hline 91.066 & $5.99 \mathrm{E}-12$ & 11.2 & $6.87 \mathrm{E}-12$ & 11.2 & 91.045 & 2.64E-09 & 8.6 & 3.39E-09 & 8.5 & 90.950 & 8.92E-09 & 8.0 & 6.84E-09 & 8.2 \\
\hline Aver & ge LI & 8.4 & & 8.4 & & & 7.0 & & 7.1 & & & 7.5 & & 7.6 \\
\hline
\end{tabular}


Table 5.5. ANS 16.1 Leach Test - Iodine Diffusivity and Leaching Indices of Cast Stone, Ceramicrete and DuraLith Monoliths

\begin{tabular}{|c|c|c|c|c|c|c|c|c|c|c|c|c|c|c|}
\hline \multicolumn{5}{|c|}{ Cast Stone } & \multicolumn{5}{|c|}{ Ceramicrete } & \multicolumn{5}{|c|}{ DuraLith } \\
\hline $\begin{array}{l}\text { Sampling } \\
\text { Days }\end{array}$ & $\begin{array}{l}\text { Specimen } 1 \\
\mathrm{D}\left(\mathrm{cm}^{2} / \mathrm{s}\right)\end{array}$ & LI & $\begin{array}{c}\text { Specimen } 2 \\
\mathrm{D}\left(\mathrm{cm}^{2} / \mathrm{s}\right)\end{array}$ & LI & $\begin{array}{c}\text { Sampling } \\
\text { Days }\end{array}$ & $\begin{array}{l}\text { Specimen } 1 \\
\mathrm{D}\left(\mathrm{cm}^{2} / \mathrm{s}\right)\end{array}$ & LI & $\begin{array}{c}\text { Specimen } 2 \\
\mathrm{D}\left(\mathrm{cm}^{2} / \mathrm{s}\right)\end{array}$ & LI & $\begin{array}{c}\text { Sampling } \\
\text { Days }\end{array}$ & $\begin{array}{l}\text { Specimen } 1 \\
\mathrm{D}\left(\mathrm{cm}^{2} / \mathrm{s}\right)\end{array}$ & LI & $\begin{array}{c}\text { Specimen } 2 \\
\mathrm{D}\left(\mathrm{cm}^{2} / \mathrm{s}\right)\end{array}$ & LI \\
\hline 0.097 & $2.42 \mathrm{E}-07$ & 6.6 & $1.65 \mathrm{E}-07$ & 6.8 & 0.096 & $<1.15 \mathrm{E}-08$ & $>7.9$ & $<1.19 \mathrm{E}-08$ & $>7.9$ & 0.092 & $5.08 \mathrm{E}-09$ & 8.3 & $7.21 \mathrm{E}-09$ & 8.1 \\
\hline 0.294 & 3.37E-07 & 6.5 & $2.73 \mathrm{E}-07$ & 6.6 & 0.274 & $<2.41 \mathrm{E}-08$ & $>7.6$ & $<2.48 \mathrm{E}-08$ & $>7.6$ & 0.296 & 3.53E-09 & 8.5 & $6.38 \mathrm{E}-09$ & 8.2 \\
\hline 1.012 & $1.35 \mathrm{E}-07$ & 6.9 & $1.21 \mathrm{E}-07$ & 6.9 & 0.993 & $<4.94 \mathrm{E}-09$ & $>8.3$ & $<5.08 \mathrm{E}-09$ & $>8.3$ & 1.010 & $1.30 \mathrm{E}-09$ & 8.9 & 1.07E-08 & 8.0 \\
\hline 1.999 & $6.07 \mathrm{E}-08$ & 7.2 & $5.78 \mathrm{E}-08$ & 7.2 & 1.981 & $<6.54 \mathrm{E}-09$ & $>8.2$ & $<6.73 \mathrm{E}-09$ & $>8.2$ & 2.015 & 4.28E-08 & 7.4 & $1.62 \mathrm{E}-08$ & 7.8 \\
\hline 3.009 & $3.41 \mathrm{E}-08$ & 7.5 & $1.96 \mathrm{E}-08$ & 7.7 & 2.990 & $<1.07 \mathrm{E}-08$ & $>8.0$ & $<1.10 \mathrm{E}-08$ & $>8.0$ & 3.001 & $6.22 \mathrm{E}-08$ & 7.2 & $1.05 \mathrm{E}-07$ & 7.0 \\
\hline 4.014 & $2.85 \mathrm{E}-08$ & 7.5 & $2.56 \mathrm{E}-08$ & 7.6 & 3.996 & $<1.52 \mathrm{E}-08$ & $>7.8$ & $<1.56 \mathrm{E}-08$ & $>7.8$ & 4.001 & $6.16 \mathrm{E}-08$ & 7.2 & $9.49 \mathrm{E}-08$ & 7.0 \\
\hline 5.017 & $<2.51 \mathrm{E}-08$ & $>7.6$ & $<2.28 \mathrm{E}-08$ & $>7.6$ & 4.999 & $<1.97 \mathrm{E}-08$ & $>7.7$ & $<2.02 \mathrm{E}-08$ & $>7.7$ & 5.001 & $5.16 \mathrm{E}-08$ & 7.3 & $1.00 \mathrm{E}-07$ & 7.0 \\
\hline 21.061 & $6.59 \mathrm{E}-09$ & 8.2 & $5.98 \mathrm{E}-09$ & 8.2 & 21.045 & $<2.00 \mathrm{E}-10$ & $>9.7$ & $<2.05 \mathrm{E}-10$ & $>9.7$ & 21.013 & $1.27 \mathrm{E}-08$ & 7.9 & 1.67E-08 & 7.8 \\
\hline 49.066 & $3.11 \mathrm{E}-09$ & 8.5 & 2.83E-09 & 8.5 & 49.045 & $<1.89 \mathrm{E}-10$ & $>9.7$ & $<1.95 \mathrm{E}-10$ & $>9.7$ & 49.019 & $1.43 \mathrm{E}-08$ & 7.8 & $1.58 \mathrm{E}-08$ & 7.8 \\
\hline 91.066 & $<1.99 \mathrm{E}-09$ & $>8.7$ & $<1.83 \mathrm{E}-09$ & $>8.7$ & 91.045 & $<6.85 \mathrm{E}-10$ & $>9.2$ & $<7.05 \mathrm{E}-10$ & $>9.2$ & 90.950 & $1.14 \mathrm{E}-08$ & 7.9 & $1.19 \mathrm{E}-08$ & 7.9 \\
\hline Aver: & ge LI & 7.5 & & 7.6 & & & $>8.4$ & & $>8.4$ & & & 7.8 & & 7.7 \\
\hline
\end{tabular}

Table 5.6. ANS 16.1 Leach Test - Sodium Diffusivity and Leaching Indices of Cast Stone, Ceramicrete and DuraLith Monoliths

\begin{tabular}{|c|c|c|c|c|c|c|c|c|c|c|c|c|c|c|}
\hline \multicolumn{5}{|c|}{ Cast Stone } & \multicolumn{5}{|c|}{ Ceramicrete } & \multicolumn{5}{|c|}{ DuraLith } \\
\hline $\begin{array}{c}\text { Sampling } \\
\text { Days }\end{array}$ & $\begin{array}{c}\text { Specimen } 1 \\
\mathrm{D}\left(\mathrm{cm}^{2} / \mathrm{s}\right)\end{array}$ & LI & $\begin{array}{c}\text { Specimen } 2 \\
\mathrm{D}\left(\mathrm{cm}^{2} / \mathrm{s}\right)\end{array}$ & LI & $\begin{array}{c}\text { Sampling } \\
\text { Days }\end{array}$ & $\begin{array}{c}\text { Specimen } 1 \\
\mathrm{D}\left(\mathrm{cm}^{2} / \mathrm{s}\right)\end{array}$ & LI & $\begin{array}{c}\text { Specimen } 2 \\
\mathrm{D}\left(\mathrm{cm}^{2} / \mathrm{s}\right)\end{array}$ & LI & $\begin{array}{c}\text { Sampling } \\
\text { Days }\end{array}$ & $\begin{array}{c}\text { Specimen } 1 \\
\mathrm{D}\left(\mathrm{cm}^{2} / \mathrm{s}\right)\end{array}$ & LI & $\begin{array}{c}\text { Specimen } 2 \\
\mathrm{D}\left(\mathrm{cm}^{2} / \mathrm{s}\right)\end{array}$ & LI \\
\hline 0.097 & $1.94 \mathrm{E}-08$ & 7.7 & $1.96 \mathrm{E}-08$ & 7.7 & 0.096 & $8.32 \mathrm{E}-09$ & 8.1 & $1.05 \mathrm{E}-09$ & 9.0 & 0.092 & $2.27 \mathrm{E}-08$ & 7.6 & $1.84 \mathrm{E}-08$ & 7.7 \\
\hline 0.294 & 4.07E-08 & 7.4 & $3.78 \mathrm{E}-08$ & 7.4 & 0.274 & $1.02 \mathrm{E}-08$ & 8.0 & $1.01 \mathrm{E}-08$ & 8.0 & 0.296 & $1.75 \mathrm{E}-08$ & 7.8 & $1.57 \mathrm{E}-08$ & 7.8 \\
\hline 1.012 & $2.21 \mathrm{E}-08$ & 7.7 & 2.17E-08 & 7.7 & 0.993 & $1.22 \mathrm{E}-08$ & 7.9 & $7.55 \mathrm{E}-09$ & 8.1 & 1.010 & 3.64E-09 & 8.4 & $1.29 \mathrm{E}-08$ & 7.9 \\
\hline 1.999 & $1.44 \mathrm{E}-08$ & 7.8 & $1.41 \mathrm{E}-08$ & 7.9 & 1.981 & 9.99E-09 & 8.0 & $9.67 \mathrm{E}-09$ & 8.0 & 2.015 & $1.44 \mathrm{E}-08$ & 7.8 & $6.34 \mathrm{E}-09$ & 8.2 \\
\hline 3.009 & 7.65E-09 & 8.1 & $7.65 \mathrm{E}-09$ & 8.1 & 2.990 & $1.12 \mathrm{E}-08$ & 7.9 & $8.12 \mathrm{E}-09$ & 8.1 & 3.001 & $1.17 \mathrm{E}-08$ & 7.9 & $1.24 \mathrm{E}-08$ & 7.9 \\
\hline 4.014 & 4.44E-09 & 8.4 & $5.06 \mathrm{E}-09$ & 8.3 & 3.996 & $1.02 \mathrm{E}-08$ & 8.0 & 8.81E-09 & 8.1 & 4.001 & $1.20 \mathrm{E}-08$ & 7.9 & $1.01 \mathrm{E}-08$ & 8.0 \\
\hline 5.017 & 2.87E-09 & 8.5 & $3.48 \mathrm{E}-09$ & 8.5 & 4.999 & $9.66 \mathrm{E}-09$ & 8.0 & 7.27E-09 & 8.1 & 5.001 & $1.09 \mathrm{E}-08$ & 8.0 & 1.03E-08 & 8.0 \\
\hline 21.061 & $6.24 \mathrm{E}-10$ & 9.2 & 7.13E-10 & 9.1 & 21.045 & $6.61 \mathrm{E}-09$ & 8.2 & 5.23E-09 & 8.3 & 21.013 & $5.86 \mathrm{E}-09$ & 8.2 & $5.68 \mathrm{E}-09$ & 8.2 \\
\hline 49.066 & $1.60 \mathrm{E}-10$ & 9.8 & $1.87 \mathrm{E}-10$ & 9.7 & 49.045 & 3.33E-09 & 8.5 & $3.00 \mathrm{E}-09$ & 8.5 & 49.019 & 3.33E-09 & 8.5 & $3.27 \mathrm{E}-09$ & 8.5 \\
\hline 91.066 & $8.43 \mathrm{E}-11$ & 10.1 & $8.75 \mathrm{E}-11$ & 10.1 & 91.045 & 3.31E-09 & 8.5 & $2.54 \mathrm{E}-09$ & 8.6 & 90.949 & $1.44 \mathrm{E}-09$ & 8.8 & $1.41 \mathrm{E}-09$ & 8.9 \\
\hline \multicolumn{2}{|c|}{ Average LI } & 8.5 & & 8.4 & & & 8.1 & & 8.3 & & & 8.1 & & 8.1 \\
\hline
\end{tabular}




\subsubsection{ASTM C1308 Leach Test}

The results of the ASTM C1308 leach tests for Tc, Re, I and Na on Cast Stone 2M, Ceramicrete and DuraLith are listed in Table 5.7 - Table 5.10 and the diffusivities for the elements of interest as functions of sampling times are also shown graphically in Figure 5.19 - Figure 5.22. The data indicated good reproducibility for measurements made on duplicate monoliths of each waste form.

\subsubsection{Technetium Diffusivity}

The data for technetium for both Cast Stone and DuraLith indicated that diffusivity calculated on the basis of Cumulative Fraction Leached (CFL) for Cast Stone 2M ranged from an initial value of $\sim 4 \times 10^{-9}$ $\mathrm{cm}^{2} / \mathrm{s}$ to a final value of $\sim 1 \times 10^{-9} \mathrm{~cm}^{2} / \mathrm{s}$ (Figure 5.19). The Ceramicrete samples, however, did not show any significant change in cumulative diffusivities. The cumulative diffusivity of Tc in DuraLith specimens over the same leaching period declined by just about an order of magnitude. At the end of 11 days of leaching, these waste forms yielded cumulative diffusivities that ranged from $\sim 1 \times 10^{-9} \mathrm{~cm}^{2} / \mathrm{s}$ for Cast Stone $2 \mathrm{M}$ to $\sim 3 \times 10^{-10} \mathrm{~cm}^{2} / \mathrm{s}$ for Ceramicrete and $\sim 1 \times 10^{-10} \mathrm{~cm}^{2} / \mathrm{s}$ for DuraLith.

The calculated LI values of technetium based on the last cumulative diffusivities are 9.0 for Cast Stone 2M, 9.5 for Ceramicrete, and 9.9 for DuraLith (Table 5.7). These values for Ceramicrete and DuraLith are better than the target LI of 9 for technetium.

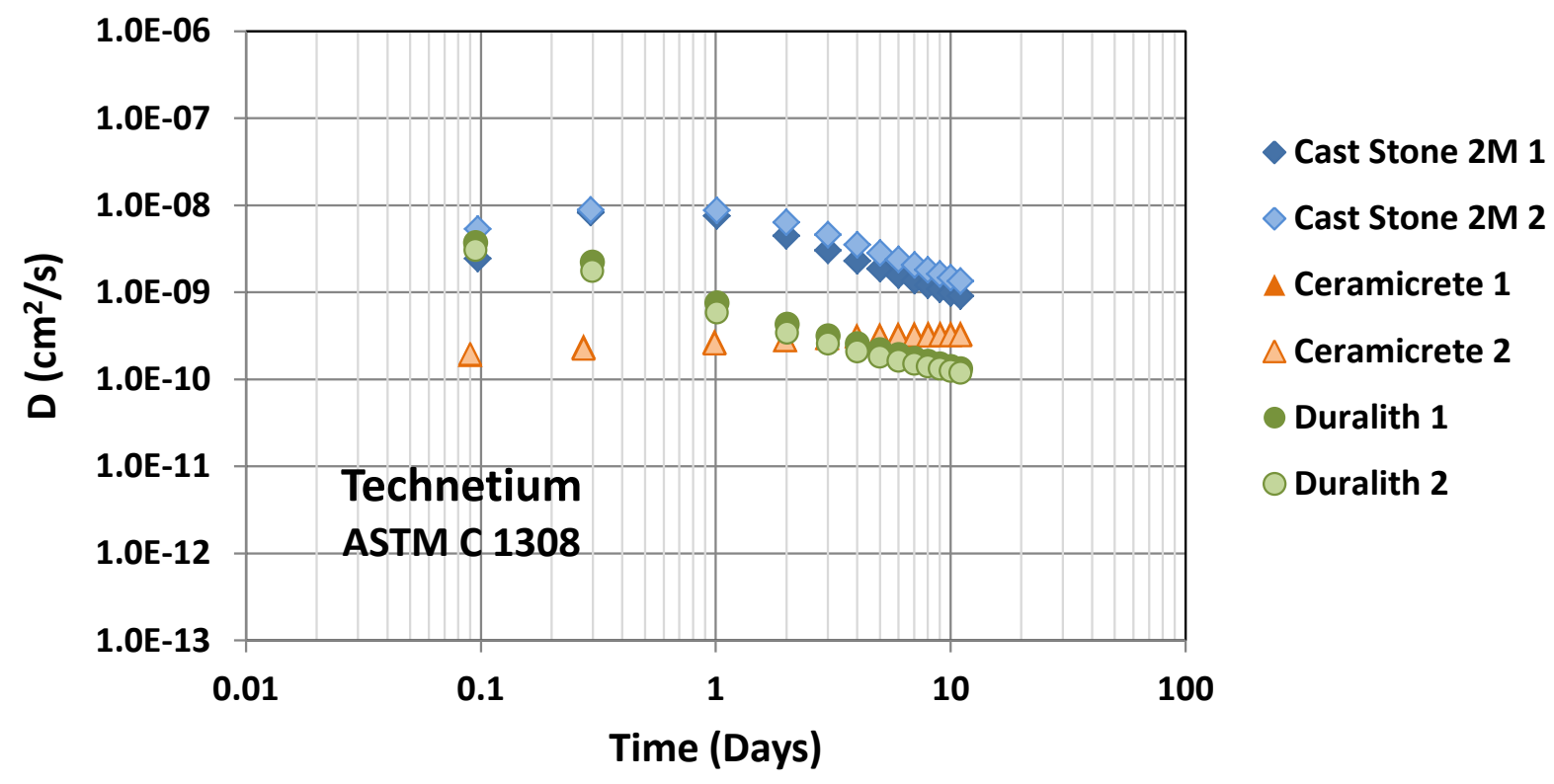

Figure 5.19. Technetium Diffusivity (ASTM C1308) of Cast Stone, Ceramicrete and DuraLith Monoliths

\subsubsection{Rhenium Diffusivity}

The Re diffusivities and LIs determined from the ASTM C1308 tests are tabulated in Table 5.8 and the diffusivities as functions of time are graphically displayed in Figure 5.20. All the waste forms showed relatively steady cumulative diffusivities over the 11-day test period. For instance, the Cast Stone $2 \mathrm{M}$ diffusivities ranged from an initial value of $\sim 6 \times 10^{-8} \mathrm{~cm}^{2} / \mathrm{s}$ to a final value of $\sim 2 \times 10^{-8} \mathrm{~cm}^{2} / \mathrm{s}$. At the end 
of 11-day leaching, the cumulative Re diffusivities in Cast Stone 2M, Ceramicrete and DuraLith were $2 \mathrm{x}$ $10^{-8} \mathrm{~cm}^{2} / \mathrm{s}, \sim 2 \times 10^{-7} \mathrm{~cm}^{2} / \mathrm{s}$ and $\sim 4 \times 10^{-8} \mathrm{~cm}^{2} / \mathrm{s}$, respectively.

The final cumulative LI values for Re were calculated to be 7.7 for Cast Stone 2M, 6.8 for Ceramicrete, and 7.4 for DuraLith (Table 5.8). None of the waste forms met the target LI $>9$ for technetium based on rhenium as a surrogate for technetium. The result again suggests that Re may not be a good surrogate for ${ }^{99} \mathrm{Tc}$ in low-temperature waste form leach studies.

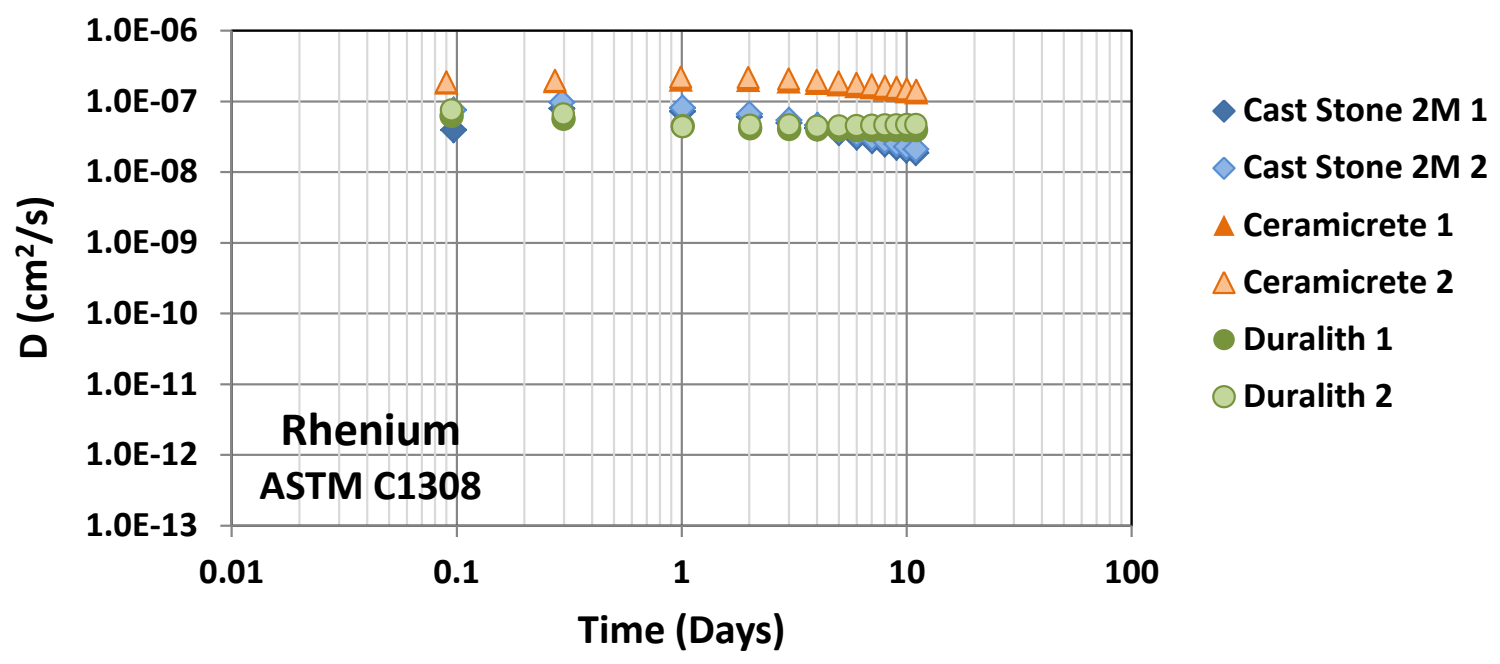

Figure 5.20. Rhenium Diffusivity (ASTM C1308) of Cast Stone, Ceramicrete and DuraLith Monoliths

\subsubsection{3 lodine Diffusivity}

The iodine diffusivities and LIs from the ASTM C1308 leach tests conducted on Cast Stone 2M, Ceramicrete and DuraLith samples are listed in Table 5.9 and the plot of diffusivity data is shown in Figure 5.21. The cumulative diffusivity of iodine in Cast Stone $2 \mathrm{M}$ was relatively constant over the four day period; however, the concentrations of iodine leachate were subsequently below detection limits. All the sampled leachates from the Ceramicrete specimens showed iodine concentrations below the detection limits; therefore, the actual diffusivity values of iodine for this waste form could not be determined.

The calculated average values of iodine LIs at the end of four days of leaching were 7.2 for Cast Stone $2 \mathrm{M}$ and for 7.8 for DuraLith respectively (Table 5.9). These values are below the target LI $>11$ for iodine. 


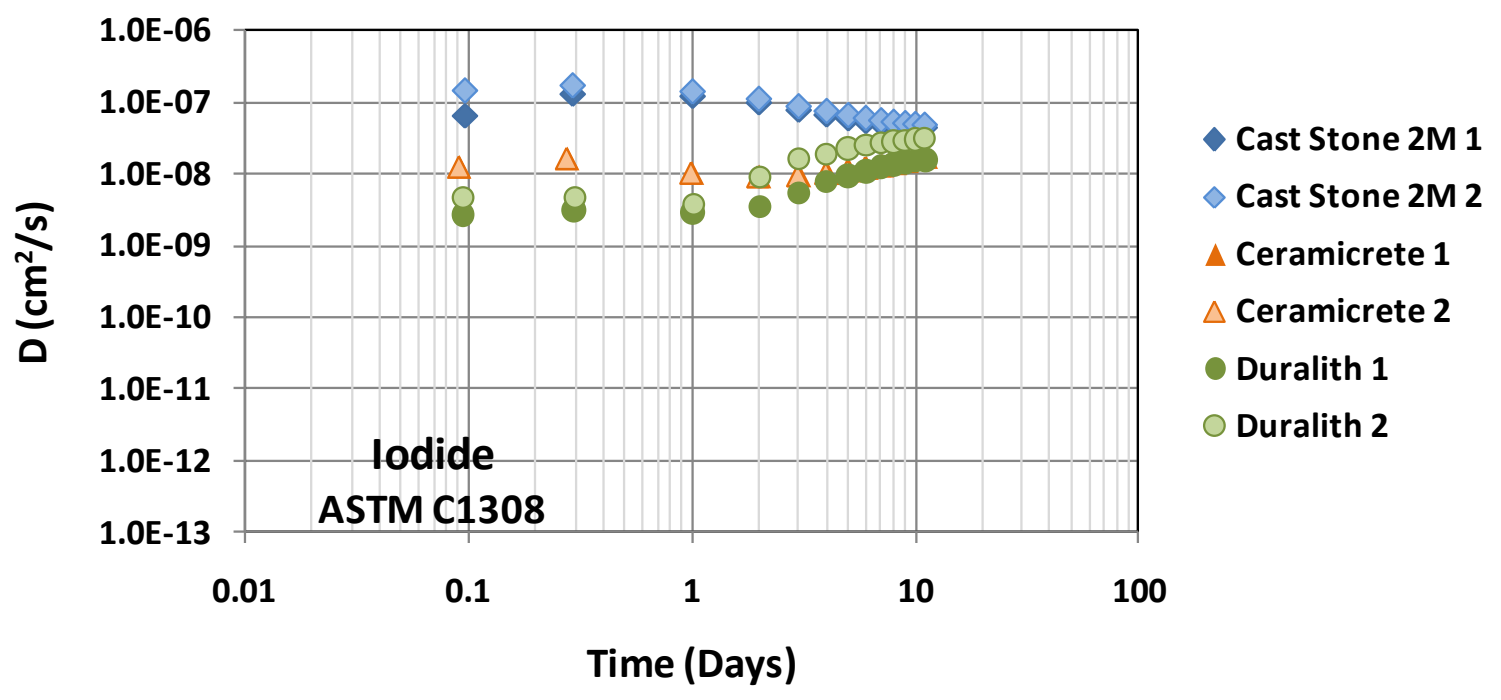

Figure 5.21. Iodine Diffusivity (ASTM C1308) of Cast Stone, Ceramicrete and DuraLith Monoliths

\subsubsection{Sodium Diffusivity}

The sodium diffusivities and LIs from the ASTM C1308 leach tests conducted on Cast Stone 2M, Ceramicrete and DuraLith samples are listed in Table 5.10 and the plot of diffusivity data is shown in Figure 5.22. All waste forms exhibited relatively constant cumulative diffusivities over the 11-day test period. At the end of the 11-day test period, the cumulative sodium diffusivity values were, on average, $\sim 8 \times 10^{-9} \mathrm{~cm}^{2} / \mathrm{s}$ for Cast Stone $2 \mathrm{M}, \sim 8 \times 10^{-9} \mathrm{~cm}^{2} / \mathrm{s}$ for Ceramicrete, and $\sim 1 \times 10^{-8} \mathrm{~cm}^{2} / \mathrm{s}$ for DuraLith (Figure 5.22, Table 5.10).

The calculated cumulative average values of sodium LIs are 8.1 for Cast Stone 2M, 8.1 for Ceramicrete and 8.1 for DuraLith (Table 5.10). These values are better than the target LI $>6.0$ for sodium. 


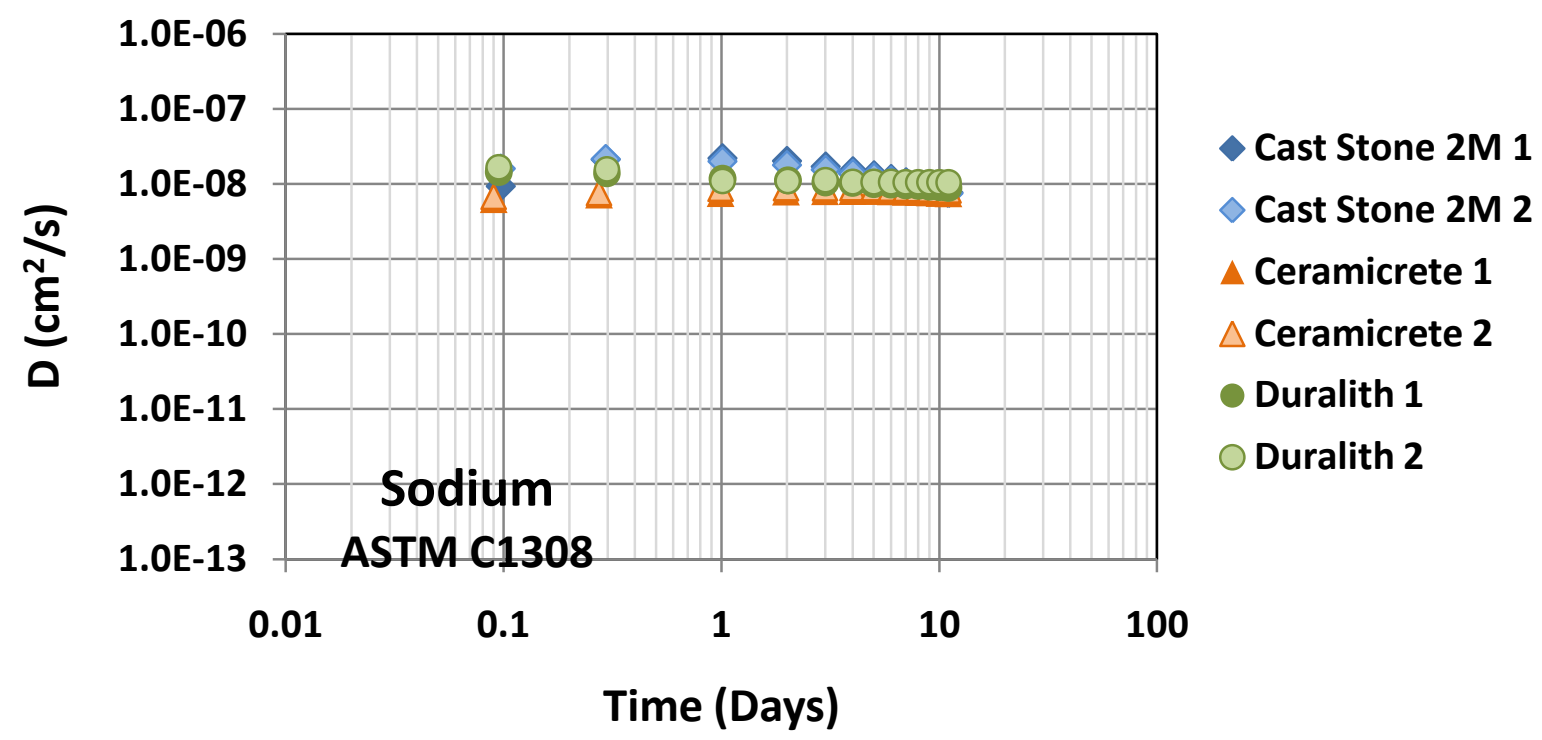

Figure 5.22. Sodium Diffusivity (ASTM C1308) of Cast Stone, Ceramicrete and DuraLith Monoliths 
Table 5.7. ASTM C1308 Leach Test - Technetium Diffusivity and Leaching Indices of Cast Stone, Ceramicrete and DuraLith Monoliths

\begin{tabular}{|c|c|c|c|c|c|c|c|c|c|c|c|c|c|c|}
\hline \multicolumn{5}{|c|}{ Cast Stone } & \multicolumn{5}{|c|}{ Ceramicrete } & \multicolumn{5}{|c|}{ DuraLith } \\
\hline $\begin{array}{l}\text { Sampling } \\
\text { Days }\end{array}$ & $\begin{array}{l}\text { Specimen } 1 \\
\mathrm{D}\left(\mathrm{cm}^{2} / \mathrm{s}\right)\end{array}$ & LI & $\begin{array}{l}\text { Specimen } 2 \\
\mathrm{D}\left(\mathrm{cm}^{2} / \mathrm{s}\right)\end{array}$ & LI & $\begin{array}{c}\text { Sampling } \\
\text { Days }\end{array}$ & $\begin{array}{l}\text { Specimen } 1 \\
\mathrm{D}\left(\mathrm{cm}^{2} / \mathrm{s}\right)\end{array}$ & LI & $\begin{array}{l}\text { Specimen } 2 \\
\mathrm{D}\left(\mathrm{cm}^{2} / \mathrm{s}\right)\end{array}$ & LI & $\begin{array}{c}\text { Sampling } \\
\text { Days }\end{array}$ & $\begin{array}{l}\text { Specimen } 1 \\
\mathrm{D}\left(\mathrm{cm}^{2} / \mathrm{s}\right)\end{array}$ & LI & $\begin{array}{l}\text { Specimen } 2 \\
\mathrm{D}\left(\mathrm{cm}^{2} / \mathrm{s}\right)\end{array}$ & LI \\
\hline 0.097 & $2.4 \mathrm{E}-09$ & 8.6 & $5.32 \mathrm{E}-09$ & 8.3 & 0.090 & $1.93 \mathrm{E}-10$ & 9.7 & $1.94 \mathrm{E}-10$ & 9.7 & 0.095 & $3.74 \mathrm{E}-09$ & 8.4 & $3.07 \mathrm{E}-09$ & 8.5 \\
\hline 0.294 & 8.2E-09 & 8.1 & 8.84E-09 & 8.1 & 0.274 & 2.39E-10 & 9.6 & $2.23 \mathrm{E}-10$ & 9.7 & 0.298 & 2.22E-09 & 8.7 & $1.75 \mathrm{E}-09$ & 8.8 \\
\hline 1.010 & 7.6E-09 & 8.1 & 8.70 E-09 & 8.1 & 0.991 & $2.73 \mathrm{E}-10$ & 9.6 & $2.57 \mathrm{E}-10$ & 9.6 & 1.012 & $7.58 \mathrm{E}-10$ & 9.1 & $5.82 \mathrm{E}-10$ & 9.2 \\
\hline 1.998 & 4.4E-09 & 8.4 & $6.38 \mathrm{E}-09$ & 8.2 & 1.979 & $2.87 \mathrm{E}-10$ & 9.5 & $2.81 \mathrm{E}-10$ & 9.6 & 2.017 & $4.31 \mathrm{E}-10$ & 9.4 & $3.41 \mathrm{E}-10$ & 9.5 \\
\hline 3.008 & $3.0 \mathrm{E}-09$ & 8.5 & 4.57E-09 & 8.3 & 2.989 & $3.04 \mathrm{E}-10$ & 9.5 & $2.95 \mathrm{E}-10$ & 9.5 & 3.003 & $3.17 \mathrm{E}-10$ & 9.5 & $2.57 \mathrm{E}-10$ & 9.6 \\
\hline 4.012 & 2.3E-09 & 8.6 & $3.50 \mathrm{E}-09$ & 8.5 & 3.994 & $3.21 \mathrm{E}-10$ & 9.5 & $3.03 \mathrm{E}-10$ & 9.5 & 4.003 & $2.57 \mathrm{E}-10$ & 9.6 & $2.08 \mathrm{E}-10$ & 9.7 \\
\hline 5.015 & $1.9 \mathrm{E}-09$ & 8.7 & 2.83E-09 & 8.5 & 4.998 & $3.27 \mathrm{E}-10$ & 9.5 & $3.09 \mathrm{E}-10$ & 9.5 & 5.003 & $2.20 \mathrm{E}-10$ & 9.7 & $1.81 \mathrm{E}-10$ & 9.7 \\
\hline 6.007 & $1.6 \mathrm{E}-09$ & 8.8 & 2.38E-09 & 8.6 & 5.990 & $3.32 \mathrm{E}-10$ & 9.5 & $3.12 \mathrm{E}-10$ & 9.5 & 6.000 & $1.93 \mathrm{E}-10$ & 9.7 & $1.63 \mathrm{E}-10$ & 9.8 \\
\hline 7.035 & $1.4 \mathrm{E}-09$ & 8.9 & $2.05 \mathrm{E}-09$ & 8.7 & 7.019 & $3.37 \mathrm{E}-10$ & 9.5 & $3.16 \mathrm{E}-10$ & 9.5 & 7.019 & $1.75 \mathrm{E}-10$ & 9.8 & $1.50 \mathrm{E}-10$ & 9.8 \\
\hline 8.001 & $1.2 \mathrm{E}-09$ & 8.9 & $1.81 \mathrm{E}-09$ & 8.7 & 8.027 & $3.40 \mathrm{E}-10$ & 9.5 & $3.16 \mathrm{E}-10$ & 9.5 & 8.004 & $1.62 \mathrm{E}-10$ & 9.8 & $1.40 \mathrm{E}-10$ & 9.9 \\
\hline 9.016 & $1.1 \mathrm{E}-09$ & 9.0 & $1.62 \mathrm{E}-09$ & 8.8 & 9.042 & $3.39 \mathrm{E}-10$ & 9.5 & $3.19 \mathrm{E}-10$ & 9.5 & 9.006 & $1.50 \mathrm{E}-10$ & 9.8 & $1.32 \mathrm{E}-10$ & 9.9 \\
\hline 10.002 & $9.8 \mathrm{E}-10$ & 9.0 & $<1.47 \mathrm{E}-09$ & $>8.8$ & 10.028 & $3.40 \mathrm{E}-10$ & 9.5 & $3.18 \mathrm{E}-10$ & 9.5 & 10.009 & $1.40 \mathrm{E}-10$ & 9.9 & $1.25 \mathrm{E}-10$ & 9.9 \\
\hline 11.008 & $9.0 \mathrm{E}-10$ & 9.0 & $1.34 \mathrm{E}-09$ & 8.9 & 11.028 & 3.39E-10 & 9.5 & $3.20 \mathrm{E}-10$ & 9.5 & 11.019 & $1.32 \mathrm{E}-10$ & 9.9 & $1.19 \mathrm{E}-10$ & 9.9 \\
\hline
\end{tabular}

Table 5.8. ASTM C1308 Leach Test - Rhenium Diffusivity and Leaching Indices of Cast Stone, Ceramicrete and DuraLith Monoliths

\begin{tabular}{|c|c|c|c|c|c|c|c|c|c|c|c|c|c|c|}
\hline \multicolumn{5}{|c|}{ Cast Stone } & \multicolumn{5}{|c|}{ Ceramicrete } & \multicolumn{5}{|c|}{ DuraLith } \\
\hline $\begin{array}{l}\text { Sampling } \\
\text { Days }\end{array}$ & $\begin{array}{l}\text { Specimen } 1 \\
\mathrm{D}\left(\mathrm{cm}^{2} / \mathrm{s}\right)\end{array}$ & LI & $\begin{array}{c}\text { Specimen } 2 \\
\mathrm{D}\left(\mathrm{cm}^{2} / \mathrm{s}\right)\end{array}$ & LI & $\begin{array}{c}\text { Sampling } \\
\text { Days }\end{array}$ & $\begin{array}{l}\text { Specimen } 1 \\
\mathrm{D}\left(\mathrm{cm}^{2} / \mathrm{s}\right)\end{array}$ & LI & $\begin{array}{c}\text { Specimen } 2 \\
\mathrm{D}\left(\mathrm{cm}^{2} / \mathrm{s}\right)\end{array}$ & LI & $\begin{array}{c}\text { Sampling } \\
\text { Days }\end{array}$ & $\begin{array}{l}\text { Specimen } 1 \\
\mathrm{D}\left(\mathrm{cm}^{2} / \mathrm{s}\right)\end{array}$ & LI & $\begin{array}{c}\text { Specimen } 2 \\
\mathrm{D}\left(\mathrm{cm}^{2} / \mathrm{s}\right)\end{array}$ & LI \\
\hline 0.097 & $3.96 \mathrm{E}-08$ & 7.4 & $7.60 \mathrm{E}-08$ & 7.1 & 0.090 & $2.19 \mathrm{E}-07$ & 6.7 & $2.18 \mathrm{E}-07$ & 6.7 & 0.095 & $6.27 \mathrm{E}-08$ & 7.2 & $7.58 \mathrm{E}-08$ & 7.1 \\
\hline 0.294 & 7.91E-08 & 7.1 & $9.66 \mathrm{E}-08$ & 7.0 & 0.274 & $2.30 \mathrm{E}-07$ & 6.6 & $2.29 \mathrm{E}-07$ & 6.6 & 0.298 & $5.69 \mathrm{E}-08$ & 7.2 & $6.66 \mathrm{E}-08$ & 7.2 \\
\hline 1.010 & $7.20 \mathrm{E}-08$ & 7.1 & $8.12 \mathrm{E}-08$ & 7.1 & 0.991 & $2.40 \mathrm{E}-07$ & 6.6 & $2.56 \mathrm{E}-07$ & 6.6 & 1.012 & $4.48 \mathrm{E}-08$ & 7.3 & $4.39 \mathrm{E}-08$ & 7.4 \\
\hline 1.998 & $6.04 \mathrm{E}-08$ & 7.2 & $6.64 \mathrm{E}-08$ & 7.2 & 1.979 & $2.38 \mathrm{E}-07$ & 6.6 & $2.54 \mathrm{E}-07$ & 6.6 & 2.017 & $4.16 \mathrm{E}-08$ & 7.4 & $4.58 \mathrm{E}-08$ & 7.3 \\
\hline 3.008 & $4.94 \mathrm{E}-08$ & 7.3 & $5.45 \mathrm{E}-08$ & 7.3 & 2.989 & 2.27E-07 & 6.6 & $2.40 \mathrm{E}-07$ & 6.6 & 3.003 & 4.09E-08 & 7.4 & 4.68E-08 & 7.3 \\
\hline 4.012 & $4.16 \mathrm{E}-08$ & 7.4 & $4.60 \mathrm{E}-08$ & 7.3 & 3.994 & $2.17 \mathrm{E}-07$ & 6.7 & $2.30 \mathrm{E}-07$ & 6.6 & 4.003 & $4.05 \mathrm{E}-08$ & 7.4 & 4.42E-08 & 7.4 \\
\hline 5.015 & $3.57 \mathrm{E}-08$ & 7.4 & $3.95 \mathrm{E}-08$ & 7.4 & 4.998 & $2.05 \mathrm{E}-07$ & 6.7 & $2.19 \mathrm{E}-07$ & 6.7 & 5.003 & $3.99 \mathrm{E}-08$ & 7.4 & $4.50 \mathrm{E}-08$ & 7.3 \\
\hline 6.007 & $3.12 \mathrm{E}-08$ & 7.5 & $3.46 \mathrm{E}-08$ & 7.5 & 5.990 & $1.96 \mathrm{E}-07$ & 6.7 & $2.09 \mathrm{E}-07$ & 6.7 & 6.000 & $3.96 \mathrm{E}-08$ & 7.4 & $4.56 \mathrm{E}-08$ & 7.3 \\
\hline 7.035 & $2.75 \mathrm{E}-08$ & 7.6 & $3.07 \mathrm{E}-08$ & 7.5 & 7.019 & $1.87 \mathrm{E}-07$ & 6.7 & $1.98 \mathrm{E}-07$ & 6.7 & 7.019 & $3.96 \mathrm{E}-08$ & 7.4 & $4.60 \mathrm{E}-08$ & 7.3 \\
\hline 8.001 & $2.48 \mathrm{E}-08$ & 7.6 & $2.77 \mathrm{E}-08$ & 7.6 & 8.027 & $1.79 \mathrm{E}-07$ & 6.7 & $1.90 \mathrm{E}-07$ & 6.7 & 8.004 & 3.95E-08 & 7.4 & 4.65E-08 & 7.3 \\
\hline 9.016 & $2.24 \mathrm{E}-08$ & 7.6 & $2.50 \mathrm{E}-08$ & 7.6 & 9.042 & $1.72 \mathrm{E}-07$ & 6.8 & $1.82 \mathrm{E}-07$ & 6.7 & 9.006 & 3.94E-08 & 7.4 & $4.68 \mathrm{E}-08$ & 7.3 \\
\hline 10.002 & $2.04 \mathrm{E}-08$ & 7.7 & $2.28 \mathrm{E}-08$ & 7.6 & 10.028 & $1.65 \mathrm{E}-07$ & 6.8 & $1.74 \mathrm{E}-07$ & 6.8 & 10.009 & $3.94 \mathrm{E}-08$ & 7.4 & $4.70 \mathrm{E}-08$ & 7.3 \\
\hline 11.008 & $1.87 \mathrm{E}-08$ & 7.7 & $2.10 \mathrm{E}-08$ & 7.7 & 11.028 & $1.59 \mathrm{E}-07$ & 6.8 & $1.68 \mathrm{E}-07$ & 6.8 & 11.019 & $3.94 \mathrm{E}-08$ & 7.4 & $4.72 \mathrm{E}-08$ & 7.3 \\
\hline
\end{tabular}


Table 5.9. ASTM C1308 Leach Test - Iodine Diffusivity and Leaching Indices of Cast Stone, Ceramicrete and DuraLith Monoliths

\begin{tabular}{|c|c|c|c|c|c|c|c|c|c|c|c|c|c|c|}
\hline \multicolumn{5}{|c|}{ Cast Stone } & \multicolumn{5}{|c|}{ Ceramicrete } & \multicolumn{5}{|c|}{ DuraLith } \\
\hline $\begin{array}{l}\text { Sampling } \\
\text { Days }\end{array}$ & $\begin{array}{c}\text { Specimen } 1 \\
\mathrm{D}\left(\mathrm{cm}^{2} / \mathrm{s}\right)\end{array}$ & LI & $\begin{array}{l}\text { Specimen } 2 \\
\mathrm{D}\left(\mathrm{cm}^{2} / \mathrm{s}\right)\end{array}$ & LI & $\begin{array}{c}\text { Sampling } \\
\text { Days }\end{array}$ & $\begin{array}{l}\text { Specimen } 1 \\
\mathrm{D}\left(\mathrm{cm}^{2} / \mathrm{s}\right)\end{array}$ & LI & $\begin{array}{l}\text { Specimen } 2 \\
\mathrm{D}\left(\mathrm{cm}^{2} / \mathrm{s}\right)\end{array}$ & LI & $\begin{array}{l}\text { Sampling } \\
\text { Days }\end{array}$ & $\begin{array}{l}\text { Specimen } 1 \\
\mathrm{D}\left(\mathrm{cm}^{2} / \mathrm{s}\right)\end{array}$ & LI & $\begin{array}{l}\text { Specimen } 2 \\
\mathrm{D}\left(\mathrm{cm}^{2} / \mathrm{s}\right)\end{array}$ & LI \\
\hline 0.097 & $6.49 \mathrm{E}-08$ & 7.2 & $1.47 \mathrm{E}-07$ & 6.8 & 0.090 & $<1.26 \mathrm{E}-08$ & $>7.9$ & $<1.27 \mathrm{E}-08$ & $>7.9$ & 0.095 & $2.72 \mathrm{E}-09$ & 8.6 & $4.79 \mathrm{E}-09$ & 8.3 \\
\hline 0.294 & $1.34 \mathrm{E}-07$ & 6.9 & $1.73 \mathrm{E}-07$ & 6.8 & 0.274 & $<1.65 \mathrm{E}-08$ & $>7.8$ & $<1.68 \mathrm{E}-08$ & $>7.8$ & 0.298 & $3.16 \mathrm{E}-09$ & 8.5 & 4.63E-09 & 8.3 \\
\hline 1.010 & $1.24 \mathrm{E}-07$ & 6.9 & $1.43 \mathrm{E}-07$ & 6.8 & 0.991 & $<1.03 \mathrm{E}-08$ & $>8.0$ & $<1.04 \mathrm{E}-08$ & $>8.0$ & 1.012 & 2.88E-09 & 8.5 & $3.80 \mathrm{E}-09$ & 8.4 \\
\hline 1.998 & $1.00 \mathrm{E}-07$ & 7.0 & $1.13 \mathrm{E}-07$ & 6.9 & 1.979 & $<9.17 \mathrm{E}-09$ & $>8.0$ & $<9.29 \mathrm{E}-09$ & $>8.0$ & 2.017 & 3.49E-09 & 8.5 & 9.19E-09 & 8.0 \\
\hline 3.008 & $7.86 \mathrm{E}-08$ & 7.1 & 8.87E-08 & 7.1 & 2.989 & $<9.49 \mathrm{E}-09$ & $>8.0$ & $<9.62 \mathrm{E}-09$ & $>8.0$ & 3.003 & $5.48 \mathrm{E}-09$ & 8.3 & $1.65 \mathrm{E}-08$ & 7.8 \\
\hline 4.012 & $6.71 \mathrm{E}-08$ & 7.2 & 7.62E-08 & 7.1 & 3.994 & $<1.02 \mathrm{E}-08$ & $>8.0$ & $<1.04 \mathrm{E}-08$ & $>8.0$ & 4.003 & 7.83E-09 & 8.1 & $1.90 \mathrm{E}-08$ & 7.7 \\
\hline 5.015 & $<5.91 \mathrm{E}-08$ & 7.2 & $<6.68 \mathrm{E}-08$ & 7.2 & 4.998 & $<1.11 \mathrm{E}-08$ & $>8.0$ & $<1.13 \mathrm{E}-08$ & $>7.9$ & 5.003 & $9.66 \mathrm{E}-09$ & 8.0 & 2.27E-08 & 7.6 \\
\hline 6.007 & $<5.41 \mathrm{E}-08$ & 7.3 & $<6.09 \mathrm{E}-08$ & 7.2 & 5.990 & $<1.21 \mathrm{E}-08$ & $>7.9$ & $<1.23 \mathrm{E}-08$ & $>7.9$ & 6.000 & $1.09 \mathrm{E}-08$ & 8.0 & $2.55 \mathrm{E}-08$ & 7.6 \\
\hline 7.035 & $<5.04 \mathrm{E}-08$ & 7.3 & $<5.66 \mathrm{E}-08$ & 7.2 & 7.019 & $<1.31 \mathrm{E}-08$ & $>7.9$ & $<1.33 \mathrm{E}-08$ & $>7.9$ & 7.019 & $1.25 \mathrm{E}-08$ & 7.9 & 2.72E-08 & 7.6 \\
\hline 8.001 & $<4.82 \mathrm{E}-08$ & 7.3 & $<5.39 \mathrm{E}-08$ & 7.3 & 8.027 & $<1.41 \mathrm{E}-08$ & $>7.8$ & $<1.44 \mathrm{E}-08$ & $>7.8$ & 8.004 & $1.36 \mathrm{E}-08$ & 7.9 & $2.85 \mathrm{E}-08$ & 7.5 \\
\hline 9.016 & $<4.63 \mathrm{E}-08$ & 7.3 & $<5.17 \mathrm{E}-08$ & 7.3 & 9.042 & $<1.52 \mathrm{E}-08$ & $>7.8$ & $<1.55 \mathrm{E}-08$ & $>7.8$ & 9.006 & $1.45 \mathrm{E}-08$ & 7.8 & $2.95 \mathrm{E}-08$ & 7.5 \\
\hline 10.002 & $<4.51 \mathrm{E}-08$ & 7.3 & $<5.02 \mathrm{E}-08$ & 7.3 & 10.028 & $<1.63 \mathrm{E}-08$ & $>7.8$ & $<1.66 \mathrm{E}-08$ & $>7.8$ & 10.009 & $1.53 \mathrm{E}-08$ & 7.8 & 3.04E-08 & 7.5 \\
\hline 11.008 & $<4.42 \mathrm{E}-08$ & 7.4 & $<4.91 \mathrm{E}-08$ & 7.3 & 11.028 & $<1.74 \mathrm{E}-08$ & $>7.8$ & $<1.77 \mathrm{E}-08$ & $>7.8$ & 11.019 & $1.59 \mathrm{E}-08$ & 7.8 & $3.12 \mathrm{E}-08$ & 7.5 \\
\hline
\end{tabular}

Table 5.10. ASTM C1308 Leach Test - Sodium Diffusivity and Leaching Indices of Cast Stone, Ceramicrete and DuraLith Monoliths

\begin{tabular}{|c|c|c|c|c|c|c|c|c|c|c|c|c|c|c|}
\hline \multicolumn{5}{|c|}{ Cast Stone } & \multicolumn{5}{|c|}{ Ceramicrete } & \multicolumn{5}{|c|}{ DuraLith } \\
\hline $\begin{array}{l}\text { Sampling } \\
\text { Days }\end{array}$ & $\begin{array}{c}\text { Specimen } 1 \\
\mathrm{D}\left(\mathrm{cm}^{2} / \mathrm{s}\right)\end{array}$ & LI & $\begin{array}{l}\text { Specimen } 2 \\
\mathrm{D}\left(\mathrm{cm}^{2} / \mathrm{s}\right)\end{array}$ & LI & $\begin{array}{c}\text { Sampling } \\
\text { Days }\end{array}$ & $\begin{array}{c}\text { Specimen } 1 \\
\mathrm{D}\left(\mathrm{cm}^{2} / \mathrm{s}\right)\end{array}$ & LI & $\begin{array}{c}\text { Specimen } 2 \\
\mathrm{D}\left(\mathrm{cm}^{2} / \mathrm{s}\right)\end{array}$ & LI & $\begin{array}{c}\text { Sampling } \\
\text { Days }\end{array}$ & $\begin{array}{c}\text { Specimen } 1 \\
\mathrm{D}\left(\mathrm{cm}^{2} / \mathrm{s}\right)\end{array}$ & LI & $\begin{array}{l}\text { Specimen } 2 \\
\mathrm{D}\left(\mathrm{cm}^{2} / \mathrm{s}\right)\end{array}$ & LI \\
\hline 0.097 & $9.29 \mathrm{E}-09$ & 8.0 & $1.60 \mathrm{E}-08$ & 7.8 & 0.090 & $6.23 \mathrm{E}-09$ & 8.2 & $6.75 \mathrm{E}-09$ & 8.2 & 0.095 & $1.44 \mathrm{E}-08$ & 7.8 & $1.66 \mathrm{E}-08$ & 7.8 \\
\hline 0.294 & $2.11 \mathrm{E}-08$ & 7.7 & $2.15 \mathrm{E}-08$ & 7.7 & 0.274 & 7.18E-09 & 8.1 & 7.57E-09 & 8.1 & 0.298 & $1.38 \mathrm{E}-08$ & 7.9 & $1.56 \mathrm{E}-08$ & 7.8 \\
\hline 1.010 & $2.20 \mathrm{E}-08$ & 7.7 & 2.00E-08 & 7.7 & 0.991 & 7.50E-09 & 8.1 & 8.64E-09 & 8.1 & 1.012 & $1.17 \mathrm{E}-08$ & 7.9 & $1.09 \mathrm{E}-08$ & 8.0 \\
\hline 1.998 & 2.02E-08 & 7.7 & $1.78 \mathrm{E}-08$ & 7.7 & 1.979 & 7.87E-09 & 8.1 & 8.78E-09 & 8.1 & 2.017 & $1.11 \mathrm{E}-08$ & 8.0 & $1.09 \mathrm{E}-08$ & 8.0 \\
\hline 3.008 & $1.70 \mathrm{E}-08$ & 7.8 & $1.54 \mathrm{E}-08$ & 7.8 & 2.989 & $7.96 \mathrm{E}-09$ & 8.1 & 8.74E-09 & 8.1 & 3.003 & $1.05 \mathrm{E}-08$ & 8.0 & $1.12 \mathrm{E}-08$ & 8.0 \\
\hline 4.012 & $1.47 \mathrm{E}-08$ & 7.8 & $1.37 \mathrm{E}-08$ & 7.9 & 3.994 & 8.00E-09 & 8.1 & 8.79E-09 & 8.1 & 4.003 & $1.02 \mathrm{E}-08$ & 8.0 & $1.06 \mathrm{E}-08$ & 8.0 \\
\hline 5.015 & $1.30 \mathrm{E}-08$ & 7.9 & $1.22 \mathrm{E}-08$ & 7.9 & 4.998 & 8.00E-09 & 8.1 & 8.78E-09 & 8.1 & 5.003 & 9.91E-09 & 8.0 & $1.06 \mathrm{E}-08$ & 8.0 \\
\hline 6.007 & $1.16 \mathrm{E}-08$ & 7.9 & $1.10 \mathrm{E}-08$ & 8.0 & 5.990 & 7.92E-09 & 8.1 & 8.67E-09 & 8.1 & 6.000 & $9.75 \mathrm{E}-09$ & 8.0 & $1.06 \mathrm{E}-08$ & 8.0 \\
\hline 7.035 & $1.05 \mathrm{E}-08$ & 8.0 & $1.00 \mathrm{E}-08$ & 8.0 & 7.019 & 7.82E-09 & 8.1 & 8.62E-09 & 8.1 & 7.019 & $9.57 \mathrm{E}-09$ & 8.0 & $1.05 \mathrm{E}-08$ & 8.0 \\
\hline 8.001 & $9.63 \mathrm{E}-09$ & 8.0 & $9.27 \mathrm{E}-09$ & 8.0 & 8.027 & 7.77E-09 & 8.1 & 8.54E-09 & 8.1 & 8.004 & 9.38E-09 & 8.0 & $1.05 \mathrm{E}-08$ & 8.0 \\
\hline 9.016 & 8.86E-09 & 8.1 & 8.57E-09 & 8.1 & 9.042 & 7.68E-09 & 8.1 & $8.45 \mathrm{E}-09$ & 8.1 & 9.006 & $9.18 \mathrm{E}-09$ & 8.0 & $1.05 \mathrm{E}-08$ & 8.0 \\
\hline 10.002 & 8.23E-09 & 8.1 & 7.96E-09 & 8.1 & 10.028 & 7.54E-09 & 8.1 & 8.30E-09 & 8.1 & 10.009 & $9.01 \mathrm{E}-09$ & 8.0 & $1.05 \mathrm{E}-08$ & 8.0 \\
\hline 11.008 & 7.67E-09 & 8.1 & 7.45E-09 & 8.1 & 11.028 & 7.46E-09 & 8.1 & 8.19E-09 & 8.1 & 11.019 & 8.83E-09 & 8.1 & $1.04 \mathrm{E}-08$ & 8.0 \\
\hline
\end{tabular}




\subsubsection{EPA 1315 Leach Test}

The calculated diffusivities and LIs for Tc, Re, I and $\mathrm{Na}$ are presented in the following sections. The results of the EPA 1315 leach tests on Cast Stone 2M, Cast Stone 4M, Cast Stone 6M, Ceramicrete and DuraLith are listed in Table 5.11 - Table 5.14 and the diffusivities for the elements of interest, namely Tc, $\mathrm{Re}$, I and Na, as functions of sampling times are also shown graphically in Figure 5.23 - Figure 5.26. The data indicated good reproducibility for measurements made on duplicate monoliths of each waste form.

\subsubsection{Technetium Diffusivity}

The data for Cast Stone 2M, Cast Stone 4M, Cast Stone 6M and DuraLith indicated a rapid decline in Tc diffusivity of after a full day of leaching (Figure 5.23) and by the end of the 63 days of leaching had decreased by about three orders of magnitude. The Ceramicrete samples, however, displayed relatively steady-state Tc leaching during the experimental period. At the end of 63 days of leaching, the Cast Stone $2 \mathrm{M}$, Cast Stone $4 \mathrm{M}$, and Cast Stone $6 \mathrm{M}$ yielded diffusivities that were $\sim 5 \times 10^{-12} \mathrm{~cm}^{2} / \mathrm{s}, \sim 1 \times 10^{-10}$ $\mathrm{cm}^{2} / \mathrm{s}$ and $\sim 6 \times 10^{-11} \mathrm{~cm}^{2} / \mathrm{s}$, respectively. In comparison, the Ceramicrete and the DuraLith specimens at the end of test period yielded diffusivity values of $\sim 3 \times 10^{-10} \mathrm{~cm}^{2} / \mathrm{s}$ and $\sim 1 \times 10^{-11} \mathrm{~cm}^{2} / \mathrm{s}$, respectively.

The average LI values for Tc were calculated to be 10.3 for Cast Stone 2M, 9.4 for Cast Stone 4M, 9.5 for Cast Stone 6M, 9.5 for Ceramicrete, and 10.6 for DuraLith (Table 5.11). All five waste forms, tested by the EPA 1315 method, met the target LI $>9$ for technetium.

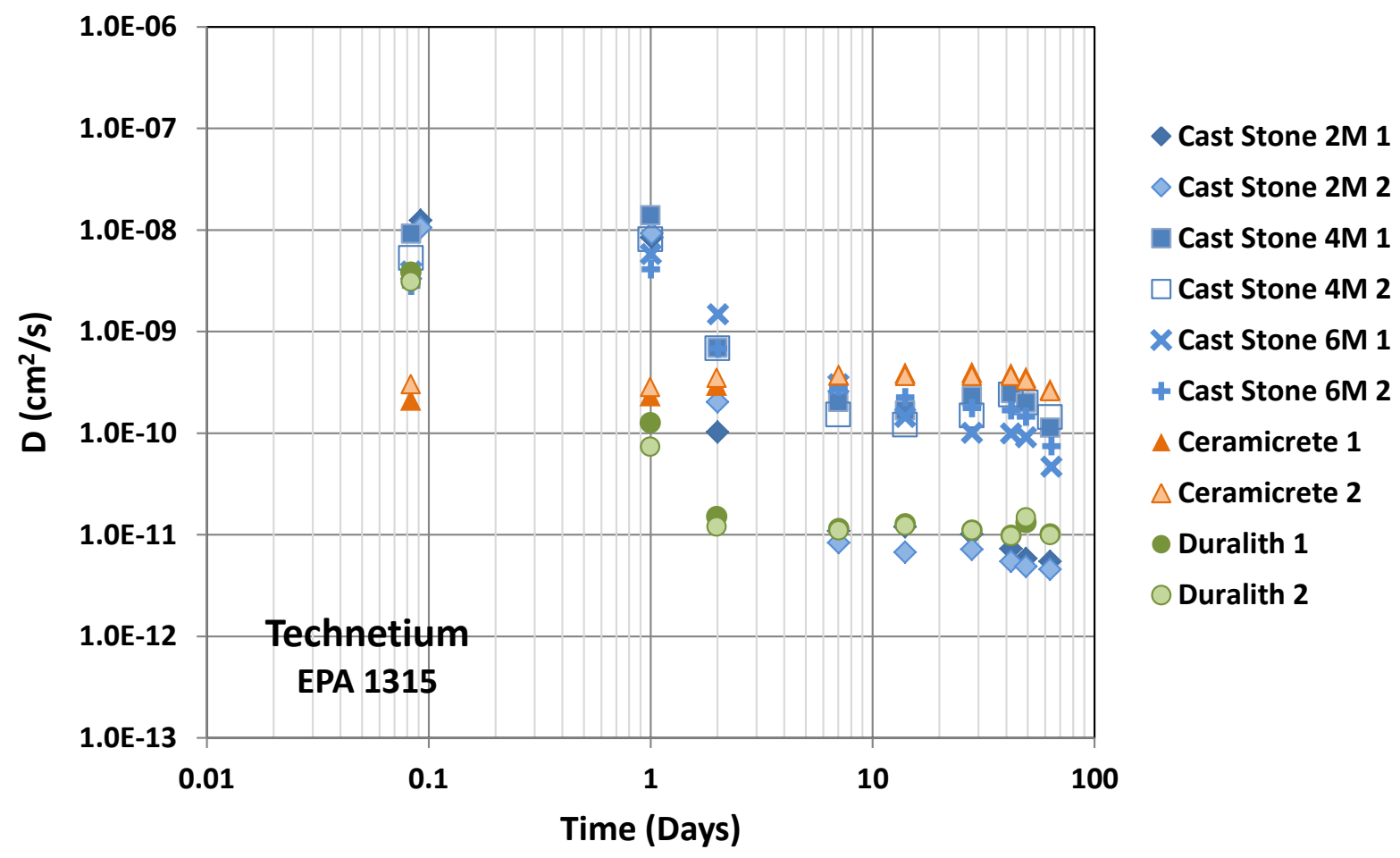

Figure 5.23. Technetium Diffusivity (EPA 1315) of Cast Stone, Ceramicrete and DuraLith Monoliths 


\subsubsection{Rhenium Diffusivity}

The Re diffusivities and LIs determined from the EPA 1315 tests are tabulated (Table 5.12) and the diffusivities as functions of time are also graphically displayed in Figure 5.24. Cast Stone 2M and 4M specimens showed very rapidly declining diffusivities of Re after one day, while the Tc diffusivity reduction curve for Cast Stone $6 \mathrm{M}$ was less steep. Gradual declines in diffusivities were noted for both Ceramicrete and DuraLith after 10 days of leaching. Cast Stone $2 \mathrm{M}$ over a 63 -day period showed about four orders of magnitude decline from initial diffusivity, whereas in both Ceramicrete and DuraLith waste forms the declines in Re diffusivities were only about an order of magnitude. The Cast Stone 4M showed two orders of magnitude reduction in Re diffusivity, and Re diffusivity from Cast Stone 6M specimens declined by about an order of magnitude. At the end of leaching experiments, the Re diffusivities in Cast Stone $2 \mathrm{M}$, Cast Stone $4 \mathrm{M}$ and Cast Stone $6 \mathrm{M}$ specimens were $\sim 8 \times 10^{-12} \mathrm{~cm}^{2} / \mathrm{s}, \sim 2 \times 10^{-10} \mathrm{~cm}^{2} / \mathrm{s}$, and $\sim 1 \times 10^{-9} \mathrm{~cm}^{2} / \mathrm{s}$ respectively. For the last intervallic leachates of the Ceramicrete and DuraLith specimens, the Re diffusivity values were $\sim 5 \times 10^{-9} \mathrm{~cm}^{2} / \mathrm{s}$ and $\sim 5 \times 10^{-9} \mathrm{~cm}^{2} / \mathrm{s}$ respectively.

The average LI values for Re were calculated to be 9.1 for Cast Stone 2M, 8.9 for Cast Stone 4M, 8.2 for Cast Stone 6M, 7.4 for Ceramicrete, and 7.8 for DuraLith (Table 5.12). Of the five waste forms tested by the EPA 1315 method, only the Cast Stone 2M met the target LI > 9 for technetium based on rhenium as a surrogate for Tc.

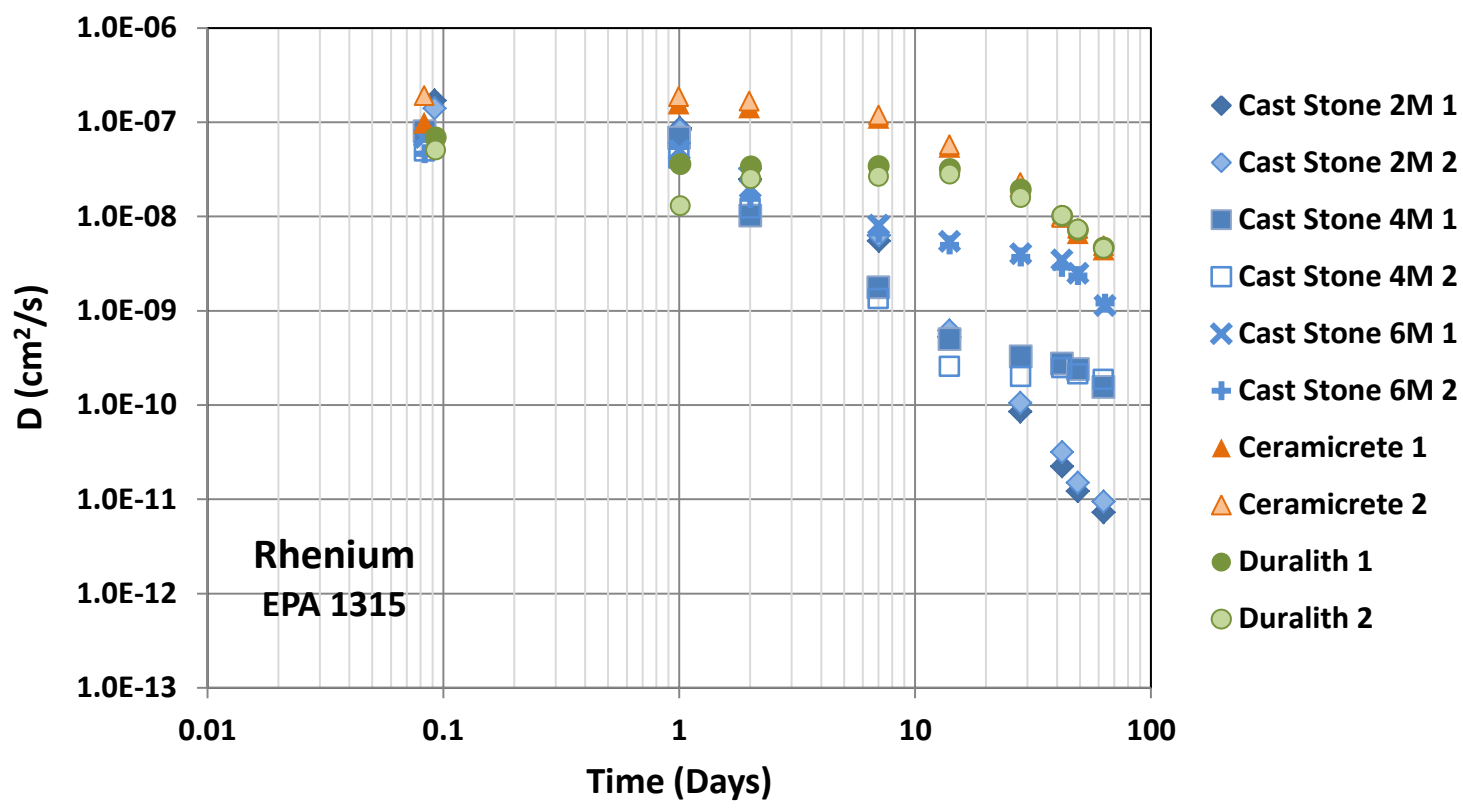

Figure 5.24. Rhenium Diffusivity (EPA 1315) of Cast Stone, Ceramicrete and DuraLith Monoliths

\subsubsection{3 lodine Diffusivity}

The iodine diffusivities and LI from the EPA 1315 leach tests conducted on Cast Stone 2M, Cast Stone 4M, Cast Stone 6M, Ceramicrete and DuraLith samples are listed in Table 5.13 and the plot of diffusivity data is shown in Figure 5.25. The diffusivities of iodine from Cast Stone 2M and 4M showed a gradual decline at every leaching interval. After 42 days of leaching, the iodine concentrations in Cast 
Stone $2 \mathrm{M}$ and $4 \mathrm{M}$ leachates were below detection limits; therefore the listed diffusivity values after this period establish only the upper-bound iodine diffusivity from this waste form. After 90 days of leaching, the diffusivity of iodine from Cast Stone 6M also declined by about two orders of magnitude. All the sampled leachates from the Ceramicrete specimens showed iodine concentrations below the detection limits; therefore, the actual diffusivity values of iodine for this waste form could not be determined. The diffusivities of iodine in DuraLith from the beginning to the end of the leaching period increased from $6 \times 10^{-9} \mathrm{~cm}^{2} / \mathrm{s}$ to $\sim 2 \times 10^{-8} \mathrm{~cm}^{2} / \mathrm{s}$.

The calculated average values of iodine LIs were 8.3 for Cast Stone $2 \mathrm{M}, 8.6$ for Cast Stone 4M, 8.0 for Cast Stone 6M, and 8.4 for DuraLith (Table 5.13). These values are below the target LI of $>11$ for iodine.

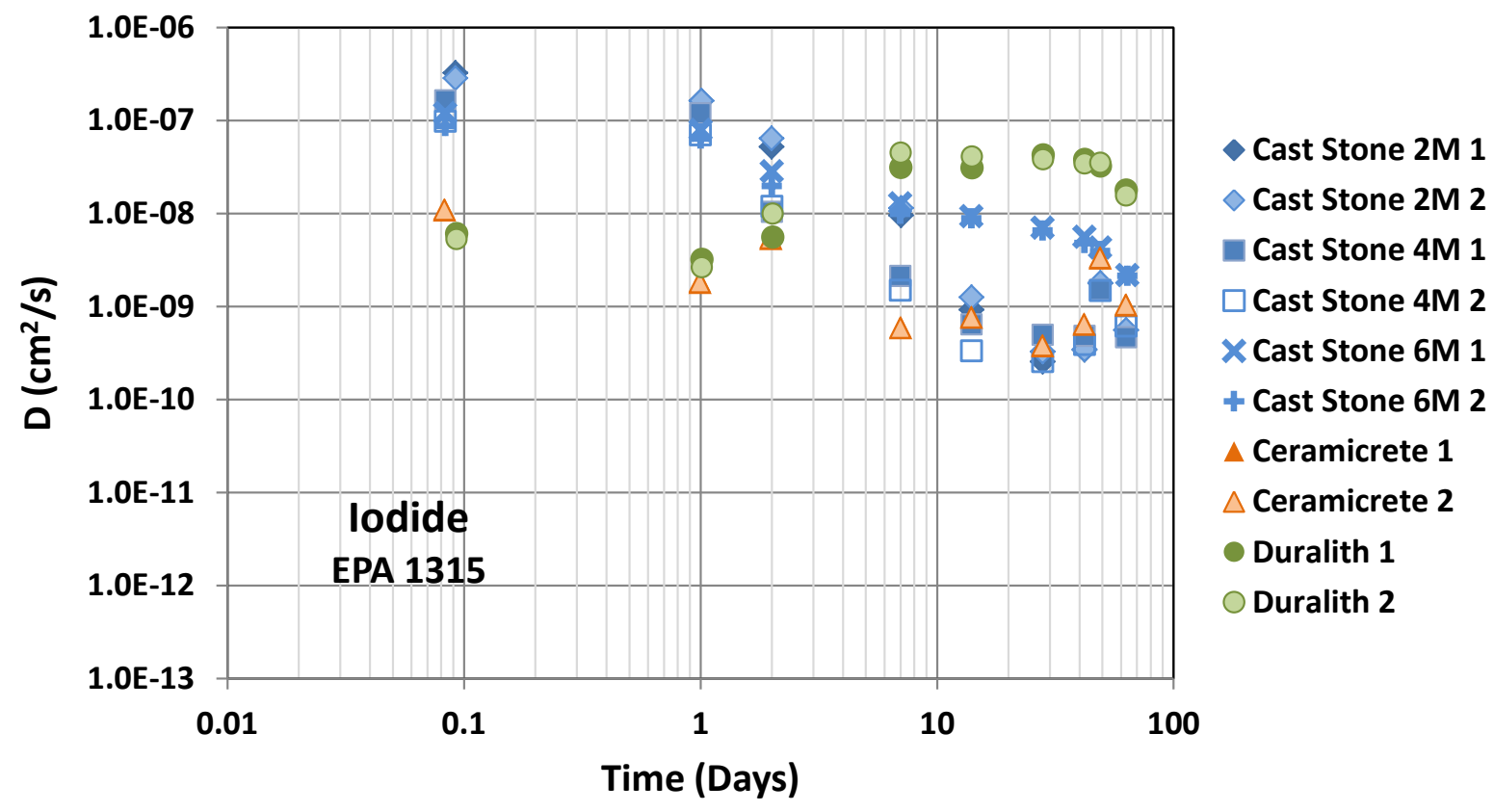

Figure 5.25. Iodine Diffusivity (EPA 1315) of Cast Stone, Ceramicrete and DuraLith Monoliths

\subsubsection{Sodium Diffusivity}

The sodium diffusivities and LIs from the EPA 1315 leach tests conducted on Cast Stone 2M, Cast stone 4M, Cast stone 6M, Ceramicrete and DuraLith samples are listed in Table 5.14 and the plot of diffusivity data is shown in Figure 5.26. Cast Stone 2M showed more than two orders of magnitude decline in sodium diffusivity from the first to the last leaching interval. During the 90-day leach period, the Cast Stone 4M and 6M specimens also exhibited about two orders of magnitude reduction in sodium diffusivity. Both Ceramicrete and DuraLith appeared to leach sodium at relatively steady rates.

The calculated average values of sodium LIs are 8.9 for Cast Stone 2M, 8.7 for Cast Stone 4M, 8.3 for Cast Stone 6M, 8.4 for Ceramicrete and 8.4 for DuraLith (Table 5.14). These values are better than the target LI > 6.0 for sodium 


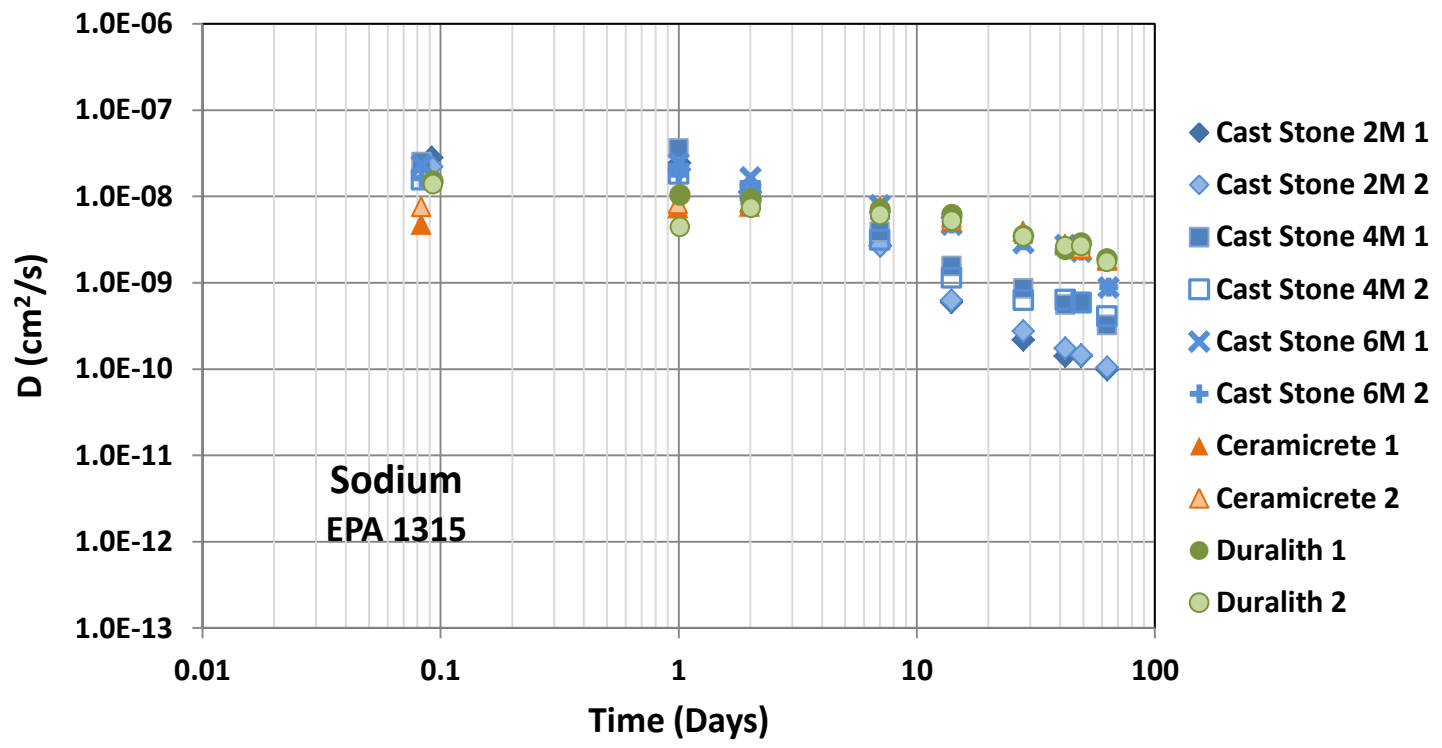

Figure 5.26. Sodium Diffusivity (EPA 1315) of Cast Stone, Ceramicrete and DuraLith Monoliths 
Table 5.11. EPA 1315 Leach Test - Technetium Diffusivity and Leaching Indices of Cast Stone, Ceramicrete and DuraLith Monoliths

\begin{tabular}{|c|c|c|c|c|c|c|c|c|c|c|c|c|c|c|}
\hline \multicolumn{5}{|c|}{ Cast Stone 2M } & \multicolumn{5}{|c|}{ Cast Stone 4M } & \multicolumn{5}{|c|}{ Cast Stone 6M } \\
\hline $\begin{array}{c}\text { Sampling } \\
\text { Days }\end{array}$ & $\begin{array}{l}\text { Specimen } 1 \\
\mathrm{D}\left(\mathrm{cm}^{2} / \mathrm{s}\right)\end{array}$ & LI & $\begin{array}{l}\text { Specimen } 2 \\
\mathrm{D}\left(\mathrm{cm}^{2} / \mathrm{s}\right)\end{array}$ & LI & $\begin{array}{c}\text { Sampling } \\
\text { Days }\end{array}$ & $\begin{array}{l}\text { Specimen } 1 \\
\mathrm{D}\left(\mathrm{cm}^{2} / \mathrm{s}\right)\end{array}$ & LI & $\begin{array}{l}\text { Specimen } 2 \\
\mathrm{D}\left(\mathrm{cm}^{2} / \mathrm{s}\right)\end{array}$ & LI & $\begin{array}{l}\text { Sampling } \\
\text { Days }\end{array}$ & $\begin{array}{l}\text { Specimen } 1 \\
\mathrm{D}\left(\mathrm{cm}^{2} / \mathrm{s}\right)\end{array}$ & LI & $\begin{array}{l}\text { Specimen } 2 \\
\mathrm{D}\left(\mathrm{cm}^{2} / \mathrm{s}\right)\end{array}$ & LI \\
\hline 0.092 & $1.24 \mathrm{E}-08$ & 7.9 & $1.05 \mathrm{E}-08$ & 8.0 & 0.083 & $9.21 \mathrm{E}-09$ & 8.0 & $5.27 \mathrm{E}-09$ & 8.3 & 0.083 & $3.90 \mathrm{E}-09$ & 8.4 & 2.83E-09 & 8.5 \\
\hline 1.010 & 8.40E-09 & 8.1 & $9.24 \mathrm{E}-09$ & 8.0 & 0.999 & $1.39 \mathrm{E}-08$ & 7.9 & $8.10 \mathrm{E}-09$ & 8.1 & 1.001 & $5.79 \mathrm{E}-09$ & 8.2 & 4.11E-09 & 8.4 \\
\hline 1.999 & $1.02 \mathrm{E}-10$ & 10.0 & $2.03 \mathrm{E}-10$ & 9.7 & 2.003 & $6.91 \mathrm{E}-10$ & 9.2 & $6.80 \mathrm{E}-10$ & 9.2 & 2.005 & $1.47 \mathrm{E}-09$ & 8.8 & $6.81 \mathrm{E}-10$ & 9.2 \\
\hline 7.037 & $1.09 \mathrm{E}-11$ & 11.0 & $8.34 \mathrm{E}-12$ & 11.1 & 6.999 & 2.03E-10 & 9.7 & $1.52 \mathrm{E}-10$ & 9.8 & 7.001 & $3.01 \mathrm{E}-10$ & 9.5 & $2.86 \mathrm{E}-10$ & 9.5 \\
\hline 14.014 & $1.19 \mathrm{E}-11$ & 10.9 & $6.73 \mathrm{E}-12$ & 11.2 & 14.012 & $1.67 \mathrm{E}-10$ & 9.8 & $1.21 \mathrm{E}-10$ & 9.9 & 14.014 & $1.44 \mathrm{E}-10$ & 9.8 & $2.25 \mathrm{E}-10$ & 9.6 \\
\hline 28.010 & $1.01 \mathrm{E}-11$ & 11.0 & 7.17E-12 & 11.1 & 28.028 & $2.30 \mathrm{E}-10$ & 9.6 & $1.49 \mathrm{E}-10$ & 9.8 & 28.030 & $1.01 \mathrm{E}-10$ & 10.0 & $1.76 \mathrm{E}-10$ & 9.8 \\
\hline 42.017 & 7.26E-12 & 11.1 & $5.44 \mathrm{E}-12$ & 11.3 & 42.008 & $2.48 \mathrm{E}-10$ & 9.6 & $2.39 \mathrm{E}-10$ & 9.6 & 42.010 & $9.91 \mathrm{E}-11$ & 10.0 & $1.67 \mathrm{E}-10$ & 9.8 \\
\hline 49.066 & $5.82 \mathrm{E}-12$ & 11.2 & $4.86 \mathrm{E}-12$ & 11.3 & 49.020 & $1.99 \mathrm{E}-10$ & 9.7 & $1.99 \mathrm{E}-10$ & 9.7 & 49.024 & $9.12 \mathrm{E}-11$ & 10.0 & $1.45 \mathrm{E}-10$ & 9.8 \\
\hline 63.038 & $5.45 \mathrm{E}-12$ & 11.3 & $4.56 \mathrm{E}-12$ & 11.3 & 62.979 & $1.13 \mathrm{E}-10$ & 9.9 & $1.43 \mathrm{E}-10$ & 9.8 & 63.983 & 4.66E-11 & 10.3 & 7.44E-11 & 10.1 \\
\hline \multicolumn{2}{|c|}{ Average LI } & 10.3 & & 10.3 & & & 9.3 & & 9.4 & & & 9.5 & & 9.4 \\
\hline \multicolumn{5}{|c|}{ Ceramicrete } & \multicolumn{5}{|c|}{ DuraLith } & & & & & \\
\hline Sampling & Specimen 1 & & Specimen 2 & & Sampling & Specimen 1 & & Specimen 2 & & & & & & \\
\hline Days & $\mathrm{D}\left(\mathrm{cm}^{2} / \mathrm{s}\right)$ & LI & $\mathrm{D}\left(\mathrm{cm}^{2} / \mathrm{s}\right)$ & LI & Days & $\mathrm{D}\left(\mathrm{cm}^{2} / \mathrm{s}\right)$ & LI & $\mathrm{D}\left(\mathrm{cm}^{2} / \mathrm{s}\right)$ & LI & & & & & \\
\hline 0.083 & $2.12 \mathrm{E}-10$ & 9.7 & 3.02E-10 & 9.5 & 0.083 & 3.86E-09 & 8.4 & 3.11E-09 & 8.5 & & & & & \\
\hline 0.995 & $2.34 \mathrm{E}-10$ & 9.6 & 2.83E-10 & 9.5 & 0.995 & $1.27 \mathrm{E}-10$ & 9.9 & 7.36E-11 & 10.1 & & & & & \\
\hline 1.983 & 2.97E-10 & 9.5 & $3.49 \mathrm{E}-10$ & 9.5 & 1.983 & $1.51 \mathrm{E}-11$ & 10.8 & $1.20 \mathrm{E}-11$ & 10.9 & & & & & \\
\hline 7.021 & 3.72E-10 & 9.4 & $3.71 \mathrm{E}-10$ & 9.4 & 7.021 & $1.15 \mathrm{E}-11$ & 10.9 & $1.10 \mathrm{E}-11$ & 11.0 & & & & & \\
\hline 13.997 & $3.92 \mathrm{E}-10$ & 9.4 & 3.64E-10 & 9.4 & 13.997 & $1.28 \mathrm{E}-11$ & 10.9 & $1.23 \mathrm{E}-11$ & 10.9 & & & & & \\
\hline 27.994 & $3.99 \mathrm{E}-10$ & 9.4 & $3.64 \mathrm{E}-10$ & 9.4 & 27.994 & $1.11 \mathrm{E}-11$ & 11.0 & $1.10 \mathrm{E}-11$ & 11.0 & & & & & \\
\hline 41.997 & $3.86 \mathrm{E}-10$ & 9.4 & 3.66E-10 & 9.4 & 41.997 & $9.90 \mathrm{E}-12$ & 11.0 & $9.73 \mathrm{E}-12$ & 11.0 & & & & & \\
\hline 49.049 & $3.54 \mathrm{E}-10$ & 9.5 & $3.30 \mathrm{E}-10$ & 9.5 & 49.049 & $1.32 \mathrm{E}-11$ & 10.9 & $1.48 \mathrm{E}-11$ & 10.8 & & & & & \\
\hline 63.017 & $2.70 \mathrm{E}-10$ & 9.6 & $2.58 \mathrm{E}-10$ & 9.6 & 63.017 & $1.02 \mathrm{E}-11$ & 11.0 & 9.91E-12 & 11.0 & & & & & \\
\hline & & 9.5 & & 9.5 & & & 10.5 & & 10.6 & & & & & \\
\hline
\end{tabular}


Table 5.12. EPA 1315 Leach Test - Rhenium Diffusivity and Leaching Indices of Cast Stone, Ceramicrete and DuraLith Monoliths

\begin{tabular}{|c|c|c|c|c|c|c|c|c|c|c|c|c|c|c|}
\hline \multicolumn{5}{|c|}{ Cast Stone 2M } & \multicolumn{5}{|c|}{ Cast Stone 4M } & \multicolumn{5}{|c|}{ Cast Stone 6M } \\
\hline $\begin{array}{l}\text { Sampling } \\
\text { Days }\end{array}$ & $\begin{array}{c}\text { Specimen } 1 \\
\mathrm{D}\left(\mathrm{cm}^{2} / \mathrm{s}\right)\end{array}$ & LI & $\begin{array}{l}\text { Specimen } 2 \\
\mathrm{D}\left(\mathrm{cm}^{2} / \mathrm{s}\right)\end{array}$ & LI & $\begin{array}{c}\text { Sampling } \\
\text { Days }\end{array}$ & $\begin{array}{c}\text { Specimen } 1 \\
\mathrm{D}\left(\mathrm{cm}^{2} / \mathrm{s}\right)\end{array}$ & LI & $\begin{array}{l}\text { Specimen } 2 \\
\mathrm{D}\left(\mathrm{cm}^{2} / \mathrm{s}\right)\end{array}$ & LI & $\begin{array}{c}\text { Sampling } \\
\text { Days }\end{array}$ & $\begin{array}{c}\text { Specimen } 1 \\
\mathrm{D}\left(\mathrm{cm}^{2} / \mathrm{s}\right)\end{array}$ & LI & $\begin{array}{l}\text { Specimen } 2 \\
\mathrm{D}\left(\mathrm{cm}^{2} / \mathrm{s}\right)\end{array}$ & LI \\
\hline 0.092 & $1.69 \mathrm{E}-07$ & 6.8 & $1.40 \mathrm{E}-07$ & 6.9 & 0.083 & $8.00 \mathrm{E}-08$ & 7.1 & $4.93 \mathrm{E}-08$ & 7.3 & 0.083 & $6.86 \mathrm{E}-08$ & 7.2 & $4.60 \mathrm{E}-08$ & 7.3 \\
\hline 1.010 & 8.63E-08 & 7.1 & $8.26 \mathrm{E}-08$ & 7.1 & 0.999 & $6.87 \mathrm{E}-08$ & 7.2 & $4.16 \mathrm{E}-08$ & 7.4 & 1.001 & 4.97E-08 & 7.3 & $3.89 \mathrm{E}-08$ & 7.4 \\
\hline 1.999 & $2.47 \mathrm{E}-08$ & 7.6 & $3.21 \mathrm{E}-08$ & 7.5 & 2.003 & $1.02 \mathrm{E}-08$ & 8.0 & $1.23 \mathrm{E}-08$ & 7.9 & 2.005 & $1.98 \mathrm{E}-08$ & 7.7 & $1.53 \mathrm{E}-08$ & 7.8 \\
\hline 7.037 & $5.49 \mathrm{E}-09$ & 8.3 & $6.29 \mathrm{E}-09$ & 8.2 & 6.999 & $1.78 \mathrm{E}-09$ & 8.7 & $1.34 \mathrm{E}-09$ & 8.9 & 7.001 & 8.04E-09 & 8.1 & $6.62 \mathrm{E}-09$ & 8.2 \\
\hline 14.014 & $5.27 \mathrm{E}-10$ & 9.3 & $6.18 \mathrm{E}-10$ & 9.2 & 14.012 & $4.99 \mathrm{E}-10$ & 9.3 & $2.57 \mathrm{E}-10$ & 9.6 & 14.014 & $5.42 \mathrm{E}-09$ & 8.3 & 4.95E-09 & 8.3 \\
\hline 28.010 & $8.48 \mathrm{E}-11$ & 10.1 & $1.05 \mathrm{E}-10$ & 10.0 & 28.028 & $3.28 \mathrm{E}-10$ & 9.5 & $2.01 \mathrm{E}-10$ & 9.7 & 28.030 & 4.01E-09 & 8.4 & 3.69E-09 & 8.4 \\
\hline 42.017 & $2.23 \mathrm{E}-11$ & 10.7 & $3.16 \mathrm{E}-11$ & 10.5 & 42.008 & $2.75 \mathrm{E}-10$ & 9.6 & $2.48 \mathrm{E}-10$ & 9.6 & 42.010 & $3.44 \mathrm{E}-09$ & 8.5 & $2.87 \mathrm{E}-09$ & 8.5 \\
\hline 49.066 & $1.22 \mathrm{E}-11$ & 10.9 & $1.50 \mathrm{E}-11$ & 10.8 & 49.020 & $2.40 \mathrm{E}-10$ & 9.6 & $2.13 \mathrm{E}-10$ & 9.7 & 49.024 & $2.48 \mathrm{E}-09$ & 8.6 & 2.35E-09 & 8.6 \\
\hline 63.038 & $7.26 \mathrm{E}-12$ & 11.1 & $9.43 \mathrm{E}-12$ & 11.0 & 62.979 & $1.56 \mathrm{E}-10$ & 9.8 & $1.87 \mathrm{E}-10$ & 9.7 & 63.983 & $1.13 \mathrm{E}-09$ & 8.9 & 1.19E-09 & 8.9 \\
\hline \multicolumn{2}{|c|}{ Average LI } & 9.1 & & 9.0 & & & 8.8 & & 8.9 & & & 8.1 & & 8.2 \\
\hline \multicolumn{5}{|c|}{ Ceramicrete } & \multicolumn{5}{|c|}{ DuraLith } & & & & & \\
\hline $\begin{array}{c}\text { Sampling } \\
\text { Days }\end{array}$ & $\begin{array}{c}\text { Specimen } 1 \\
\mathrm{D}\left(\mathrm{cm}^{2} / \mathrm{s}\right)\end{array}$ & LI & $\begin{array}{l}\text { Specimen } 2 \\
\mathrm{D}\left(\mathrm{cm}^{2} / \mathrm{s}\right)\end{array}$ & LI & $\begin{array}{c}\text { Sampling } \\
\text { Days }\end{array}$ & $\begin{array}{l}\text { Specimen } 1 \\
\mathrm{D}\left(\mathrm{cm}^{2} / \mathrm{s}\right)\end{array}$ & LI & $\begin{array}{l}\text { Specimen } 2 \\
\mathrm{D}\left(\mathrm{cm}^{2} / \mathrm{s}\right)\end{array}$ & LI & & & & & \\
\hline 0.083 & $1.17 \mathrm{E}-07$ & 6.9 & $2.23 \mathrm{E}-07$ & 6.7 & 0.093 & $6.90 \mathrm{E}-08$ & 7.2 & 5.07E-08 & 7.3 & & & & & \\
\hline 0.995 & $1.86 \mathrm{E}-07$ & 6.7 & $2.18 \mathrm{E}-07$ & 6.7 & 1.012 & $3.58 \mathrm{E}-08$ & 7.4 & $1.30 \mathrm{E}-08$ & 7.9 & & & & & \\
\hline 1.983 & $1.68 \mathrm{E}-07$ & 6.8 & $1.94 \mathrm{E}-07$ & 6.7 & 2.017 & $3.40 \mathrm{E}-08$ & 7.5 & $2.51 \mathrm{E}-08$ & 7.6 & & & & & \\
\hline 7.021 & $1.31 \mathrm{E}-07$ & 6.9 & $1.39 \mathrm{E}-07$ & 6.9 & 7.017 & $3.43 \mathrm{E}-08$ & 7.5 & $2.66 \mathrm{E}-08$ & 7.6 & & & & & \\
\hline 13.997 & $6.45 \mathrm{E}-08$ & 7.2 & $6.73 \mathrm{E}-08$ & 7.2 & 14.060 & $3.19 \mathrm{E}-08$ & 7.5 & $2.80 \mathrm{E}-08$ & 7.6 & & & & & \\
\hline 27.994 & $2.49 \mathrm{E}-08$ & 7.6 & $2.66 \mathrm{E}-08$ & 7.6 & 28.035 & $1.93 \mathrm{E}-08$ & 7.7 & $1.58 \mathrm{E}-08$ & 7.8 & & & & & \\
\hline 41.997 & $1.22 \mathrm{E}-08$ & 7.9 & $1.14 \mathrm{E}-08$ & 7.9 & 42.060 & $1.01 \mathrm{E}-08$ & 8.0 & $1.02 \mathrm{E}-08$ & 8.0 & & & & & \\
\hline 49.049 & $7.85 \mathrm{E}-09$ & 8.1 & $8.68 \mathrm{E}-09$ & 8.1 & 49.019 & 7.21E-09 & 8.1 & 7.34E-09 & 8.1 & & & & & \\
\hline 63.017 & $5.28 \mathrm{E}-09$ & 8.3 & $5.68 \mathrm{E}-09$ & 8.2 & 63.001 & 4.68E-09 & 8.3 & 4.57E-09 & 8.3 & & & & & \\
\hline & & 7.4 & & 7.3 & & & 7.7 & & 7.8 & & & & & \\
\hline
\end{tabular}


Table 5.13. EPA1315 Leach Test - Iodine Diffusivity and Leaching Indices of Cast Stone, Ceramicrete and DuraLith Monoliths

\begin{tabular}{|c|c|c|c|c|c|c|c|c|c|c|c|c|c|c|}
\hline \multicolumn{5}{|c|}{ Cast Stone 2M } & \multicolumn{5}{|c|}{ Cast Stone 4M } & \multicolumn{5}{|c|}{ Cast Stone 6M } \\
\hline $\begin{array}{c}\text { Sampling } \\
\text { Days }\end{array}$ & $\begin{array}{c}\text { Specimen } 1 \\
\mathrm{D}\left(\mathrm{cm}^{2} / \mathrm{s}\right)\end{array}$ & LI & $\begin{array}{l}\text { Specimen } 2 \\
\mathrm{D}\left(\mathrm{cm}^{2} / \mathrm{s}\right)\end{array}$ & LI & $\begin{array}{c}\text { Sampling } \\
\text { Days }\end{array}$ & $\begin{array}{c}\text { Specimen } 1 \\
\mathrm{D}\left(\mathrm{cm}^{2} / \mathrm{s}\right)\end{array}$ & LI & $\begin{array}{c}\text { Specimen } 2 \\
\mathrm{D}\left(\mathrm{cm}^{2} / \mathrm{s}\right)\end{array}$ & LI & $\begin{array}{c}\text { Sampling } \\
\text { Days }\end{array}$ & $\begin{array}{c}\text { Specimen } 1 \\
\mathrm{D}\left(\mathrm{cm}^{2} / \mathrm{s}\right)\end{array}$ & LI & $\begin{array}{l}\text { Specimen } 2 \\
\mathrm{D}\left(\mathrm{cm}^{2} / \mathrm{s}\right)\end{array}$ & LI \\
\hline 0.092 & $3.49 \mathrm{E}-07$ & 6.5 & $3.07 \mathrm{E}-07$ & 6.5 & 0.083 & $1.64 \mathrm{E}-07$ & 6.8 & $9.72 \mathrm{E}-08$ & 7.0 & 0.083 & $1.21 \mathrm{E}-07$ & 6.9 & $8.71 \mathrm{E}-08$ & 7.1 \\
\hline 1.010 & $1.75 \mathrm{E}-07$ & 6.8 & $1.76 \mathrm{E}-07$ & 6.8 & 0.999 & 1.19E-07 & 6.9 & $6.97 \mathrm{E}-08$ & 7.2 & 1.001 & $7.90 \mathrm{E}-08$ & 7.1 & $6.38 \mathrm{E}-08$ & 7.2 \\
\hline 1.999 & $5.64 \mathrm{E}-08$ & 7.2 & $6.92 \mathrm{E}-08$ & 7.2 & 2.003 & $1.04 \mathrm{E}-08$ & 8.0 & $1.19 \mathrm{E}-08$ & 7.9 & 2.005 & $2.85 \mathrm{E}-08$ & 7.5 & $1.98 \mathrm{E}-08$ & 7.7 \\
\hline 7.037 & $1.02 \mathrm{E}-08$ & 8.0 & $1.24 \mathrm{E}-08$ & 7.9 & 6.999 & $2.12 \mathrm{E}-09$ & 8.7 & 1.49E-09 & 8.8 & 7.001 & $1.29 \mathrm{E}-08$ & 7.9 & $9.89 \mathrm{E}-09$ & 8.0 \\
\hline 14.014 & $9.95 \mathrm{E}-10$ & 9.0 & $1.35 \mathrm{E}-09$ & 8.9 & 14.012 & $6.41 \mathrm{E}-10$ & 9.2 & $<3.31 \mathrm{E}-10$ & $>9.5$ & 14.014 & $9.36 \mathrm{E}-09$ & 8.0 & 8.87E-09 & 8.1 \\
\hline 28.010 & $2.76 \mathrm{E}-10$ & 9.6 & $3.53 \mathrm{E}-10$ & 9.5 & 28.028 & 4.93E-10 & 9.3 & $2.55 \mathrm{E}-10$ & 9.6 & 28.030 & 7.06E-09 & 8.2 & $6.57 \mathrm{E}-09$ & 8.2 \\
\hline 42.017 & $<3.70 \mathrm{E}-10$ & $>9.4$ & $<3.73 \mathrm{E}-10$ & $>9.4$ & 42.008 & $4.79 \mathrm{E}-10$ & 9.3 & $3.86 \mathrm{E}-10$ & 9.4 & 42.01 & $5.62 \mathrm{E}-09$ & 8.3 & $4.82 \mathrm{E}-09$ & 8.3 \\
\hline 49.066 & $<1.92 \mathrm{E}-09$ & $>8.7$ & $<1.93 \mathrm{E}-09$ & $>8.7$ & 49.020 & $<1.50 \mathrm{E}-09$ & $>8.8$ & $<1.47 \mathrm{E}-09$ & $>8.8$ & 49.02 & 4.29E-09 & 8.4 & 3.93E-09 & 8.4 \\
\hline 63.038 & $<5.99 \mathrm{E}-10$ & $>9.2$ & $<6.03 \mathrm{E}-10$ & $>9.2$ & 62.979 & $<4.65 \mathrm{E}-10$ & $>9.3$ & $<6.11 \mathrm{E}-10$ & $>9.2$ & 63.98 & 2.17E-09 & 8.7 & $2.14 \mathrm{E}-09$ & 8.7 \\
\hline \multicolumn{2}{|c|}{ Average LI } & 8.3 & & 8.3 & & & 8.5 & & 8.6 & & & 7.9 & & 8.0 \\
\hline \multicolumn{5}{|c|}{ Ceramicrete } & \multicolumn{5}{|c|}{ DuraLith } & & & & & \\
\hline $\begin{array}{c}\text { Sampling } \\
\text { Days }\end{array}$ & $\begin{array}{c}\text { Specimen } 1 \\
\mathrm{D}\left(\mathrm{cm}^{2} / \mathrm{s}\right)\end{array}$ & LI & $\begin{array}{c}\text { Specimen } 2 \\
\mathrm{D}\left(\mathrm{cm}^{2} / \mathrm{s}\right)\end{array}$ & LI & $\begin{array}{c}\text { Sampling } \\
\text { Days }\end{array}$ & $\begin{array}{c}\text { Specimen } 1 \\
\mathrm{D}\left(\mathrm{cm}^{2} / \mathrm{s}\right)\end{array}$ & LI & $\begin{array}{c}\text { Specimen } 2 \\
\mathrm{D}\left(\mathrm{cm}^{2} / \mathrm{s}\right)\end{array}$ & LI & & & & & \\
\hline 0.083 & $<1.09 \mathrm{E}-08$ & $>8.0$ & $<1.09 \mathrm{E}-08$ & $>8.0$ & 0.093 & $6.09 \mathrm{E}-09$ & 8.2 & $5.27 \mathrm{E}-09$ & 8.3 & & & & & \\
\hline 0.995 & $<1.81 \mathrm{E}-09$ & $>8.7$ & $<1.81 \mathrm{E}-09$ & $>8.7$ & 1.012 & $3.21 \mathrm{E}-09$ & 8.5 & 2.64E-09 & 8.6 & & & & & \\
\hline 1.983 & $<5.40 \mathrm{E}-09$ & $>8.3$ & $<5.39 \mathrm{E}-09$ & $>8.3$ & 2.017 & $5.56 \mathrm{E}-09$ & 8.3 & $9.91 \mathrm{E}-09$ & 8.0 & & & & & \\
\hline 7.021 & $<5.90 \mathrm{E}-10$ & $>9.2$ & $<5.89 \mathrm{E}-10$ & $>9.2$ & 7.017 & $3.12 \mathrm{E}-08$ & 7.5 & 4.48E-08 & 7.3 & & & & & \\
\hline 13.997 & $<7.63 \mathrm{E}-10$ & $>9.1$ & $<7.62 \mathrm{E}-10$ & $>9.1$ & 14.060 & $3.10 \mathrm{E}-08$ & 7.5 & $4.08 \mathrm{E}-08$ & 7.4 & & & & & \\
\hline 27.994 & $<3.79 \mathrm{E}-10$ & $>9.4$ & $<3.78 \mathrm{E}-10$ & $>9.4$ & 28.035 & $4.25 \mathrm{E}-08$ & 7.4 & 3.81E-08 & 7.4 & & & & & \\
\hline 41.997 & $<6.43 \mathrm{E}-10$ & $>9.2$ & $<6.41 \mathrm{E}-10$ & $>9.2$ & 42.060 & $3.81 \mathrm{E}-08$ & 7.4 & $3.43 \mathrm{E}-08$ & 7.5 & & & & & \\
\hline 49.049 & $<3.32 \mathrm{E}-09$ & $>8.5$ & $<3.32 \mathrm{E}-09$ & $>8.5$ & 49.019 & $3.24 \mathrm{E}-08$ & 7.5 & $3.51 \mathrm{E}-08$ & 7.5 & & & & & \\
\hline \multirow[t]{2}{*}{63.017} & $<1.04 \mathrm{E}-09$ & $>9.0$ & $<1.04 \mathrm{E}-09$ & $>9.0$ & 63.011 & $1.79 \mathrm{E}-08$ & 7.7 & $1.56 \mathrm{E}-08$ & 7.8 & & & & & \\
\hline & & $>8.8$ & & $>8.8$ & & & 7.8 & & 7.7 & & & & & \\
\hline
\end{tabular}


Table 5.14. EPA 1315 Leach Test - Sodium Diffusivity and Leaching Indices of Cast Stone, Ceramicrete and DuraLith Monoliths

\begin{tabular}{|c|c|c|c|c|c|c|c|c|c|c|c|c|c|c|}
\hline \multicolumn{5}{|c|}{ Cast Stone $2 \mathrm{M}$} & \multicolumn{5}{|c|}{ Cast Stone 4M } & \multicolumn{5}{|c|}{ Cast Stone 6M } \\
\hline $\begin{array}{c}\text { Sampling } \\
\text { Days }\end{array}$ & $\begin{array}{c}\text { Specimen } 1 \\
\mathrm{D}\left(\mathrm{cm}^{2} / \mathrm{s}\right)\end{array}$ & LI & $\begin{array}{l}\text { Specimen } 2 \\
\mathrm{D}\left(\mathrm{cm}^{2} / \mathrm{s}\right)\end{array}$ & LI & $\begin{array}{c}\text { Sampling } \\
\text { Days }\end{array}$ & $\begin{array}{l}\text { Specimen } 1 \\
\mathrm{D}\left(\mathrm{cm}^{2} / \mathrm{s}\right)\end{array}$ & LI & $\begin{array}{c}\text { Specimen } 2 \\
\mathrm{D}\left(\mathrm{cm}^{2} / \mathrm{s}\right)\end{array}$ & LI & $\begin{array}{c}\text { Sampling } \\
\text { Days }\end{array}$ & $\begin{array}{c}\text { Specimen } 1 \\
\mathrm{D}\left(\mathrm{cm}^{2} / \mathrm{s}\right)\end{array}$ & LI & $\begin{array}{c}\text { Specimen } 2 \\
\mathrm{D}\left(\mathrm{cm}^{2} / \mathrm{s}\right)\end{array}$ & LI \\
\hline 0.092 & $2.81 \mathrm{E}-08$ & 7.6 & $2.22 \mathrm{E}-08$ & 7.7 & 0.083 & $2.48 \mathrm{E}-08$ & 7.6 & $1.56 \mathrm{E}-08$ & 7.8 & 0.083 & $2.30 \mathrm{E}-08$ & 7.6 & $1.63 \mathrm{E}-08$ & 7.8 \\
\hline 1.010 & $2.46 \mathrm{E}-08$ & 7.6 & 2.05E-08 & 7.7 & 0.999 & 3.59E-08 & 7.4 & $1.83 \mathrm{E}-08$ & 7.7 & 1.001 & $2.44 \mathrm{E}-08$ & 7.6 & $1.79 \mathrm{E}-08$ & 7.7 \\
\hline 1.999 & $1.12 \mathrm{E}-08$ & 8.0 & $1.12 \mathrm{E}-08$ & 7.9 & 2.003 & $1.03 \mathrm{E}-08$ & 8.0 & $1.16 \mathrm{E}-08$ & 7.9 & 2.005 & $1.66 \mathrm{E}-08$ & 7.8 & $1.19 \mathrm{E}-08$ & 7.9 \\
\hline 7.037 & 2.69E-09 & 8.6 & 2.67E-09 & 8.6 & 6.999 & $3.88 \mathrm{E}-09$ & 8.4 & $3.15 \mathrm{E}-09$ & 8.5 & 7.001 & 7.93E-09 & 8.1 & $6.54 \mathrm{E}-09$ & 8.2 \\
\hline 14.014 & $5.93 \mathrm{E}-10$ & 9.2 & $6.25 \mathrm{E}-10$ & 9.2 & 14.012 & $1.56 \mathrm{E}-09$ & 8.8 & $1.14 \mathrm{E}-09$ & 8.9 & 14.014 & 4.69E-09 & 8.3 & 4.79E-09 & 8.3 \\
\hline 28.010 & $2.18 \mathrm{E}-10$ & 9.7 & $2.74 \mathrm{E}-10$ & 9.6 & 28.028 & $8.60 \mathrm{E}-10$ & 9.1 & $6.29 \mathrm{E}-10$ & 9.2 & 28.030 & $2.89 \mathrm{E}-09$ & 8.5 & $3.06 \mathrm{E}-09$ & 8.5 \\
\hline 42.017 & $1.41 \mathrm{E}-10$ & 9.8 & $1.73 \mathrm{E}-10$ & 9.8 & 42.008 & $5.56 \mathrm{E}-10$ & 9.3 & $6.35 \mathrm{E}-10$ & 9.2 & 42.010 & 2.74E-09 & 8.6 & $2.60 \mathrm{E}-09$ & 8.6 \\
\hline 49.066 & $1.41 \mathrm{E}-10$ & 9.9 & $1.45 \mathrm{E}-10$ & 9.8 & 49.020 & 5.92E-10 & 9.2 & $5.88 \mathrm{E}-10$ & 9.2 & 49.024 & 2.29E-09 & 8.6 & 2.31E-09 & 8.6 \\
\hline 63.038 & $9.86 \mathrm{E}-11$ & 10.0 & $1.04 \mathrm{E}-10$ & 10.0 & 62.979 & $3.23 \mathrm{E}-10$ & 9.5 & $4.09 \mathrm{E}-10$ & 9.4 & 63.983 & $8.78 \mathrm{E}-10$ & 9.1 & $8.92 \mathrm{E}-10$ & 9.0 \\
\hline \multicolumn{2}{|c|}{ Average LI } & 8.9 & & 8.9 & & & 8.6 & & 8.7 & & & 8.3 & & 8.3 \\
\hline \multicolumn{5}{|c|}{ Ceramicrete } & \multicolumn{5}{|c|}{ DuraLith } & & & & & \\
\hline $\begin{array}{c}\text { Sampling } \\
\text { Days }\end{array}$ & $\begin{array}{c}\text { Specimen } 1 \\
\mathrm{D}\left(\mathrm{cm}^{2} / \mathrm{s}\right)\end{array}$ & LI & $\begin{array}{c}\text { Specimen } 2 \\
\mathrm{D}\left(\mathrm{cm}^{2} / \mathrm{s}\right)\end{array}$ & LI & $\begin{array}{c}\text { Sampling } \\
\text { Days }\end{array}$ & $\begin{array}{c}\text { Specimen } 1 \\
\mathrm{D}\left(\mathrm{cm}^{2} / \mathrm{s}\right)\end{array}$ & LI & $\begin{array}{c}\text { Specimen } 2 \\
\mathrm{D}\left(\mathrm{cm}^{2} / \mathrm{s}\right)\end{array}$ & LI & & & & & \\
\hline 0.083 & $4.81 \mathrm{E}-09$ & 8.3 & $7.56 \mathrm{E}-09$ & 8.1 & 0.093 & $1.50 \mathrm{E}-08$ & 7.8 & $1.38 \mathrm{E}-08$ & 7.9 & & & & & \\
\hline 0.995 & 7.44E-09 & 8.1 & 8.19E-09 & 8.1 & 1.012 & $1.04 \mathrm{E}-08$ & 8.0 & $4.45 \mathrm{E}-09$ & 8.4 & & & & & \\
\hline 1.983 & 7.80E-09 & 8.1 & $8.45 \mathrm{E}-09$ & 8.1 & 2.017 & $9.24 \mathrm{E}-09$ & 8.0 & 7.40E-09 & 8.1 & & & & & \\
\hline 7.021 & 7.17E-09 & 8.1 & 7.58E-09 & 8.1 & 7.017 & 7.01E-09 & 8.2 & $6.11 \mathrm{E}-09$ & 8.2 & & & & & \\
\hline 13.997 & $5.83 \mathrm{E}-09$ & 8.2 & $5.22 \mathrm{E}-09$ & 8.3 & 14.060 & $6.14 \mathrm{E}-09$ & 8.2 & $5.24 \mathrm{E}-09$ & 8.3 & & & & & \\
\hline 27.994 & $3.95 \mathrm{E}-09$ & 8.4 & 3.92E-09 & 8.4 & 28.035 & $3.52 \mathrm{E}-09$ & 8.5 & $3.42 \mathrm{E}-09$ & 8.5 & & & & & \\
\hline 41.997 & 2.77E-09 & 8.6 & 2.79E-09 & 8.6 & 42.060 & 2.44E-09 & 8.6 & 2.63E-09 & 8.6 & & & & & \\
\hline 49.049 & $2.50 \mathrm{E}-09$ & 8.6 & $2.51 \mathrm{E}-09$ & 8.6 & 49.019 & 2.87E-09 & 8.5 & $2.66 \mathrm{E}-09$ & 8.6 & & & & & \\
\hline \multirow[t]{2}{*}{63.017} & $1.91 \mathrm{E}-09$ & 8.7 & $1.81 \mathrm{E}-09$ & 8.7 & 63.001 & $1.88 \mathrm{E}-09$ & 8.7 & $1.74 \mathrm{E}-09$ & 8.8 & & & & & \\
\hline & & 8.4 & & 8.3 & & & 8.3 & & 8.4 & & & & & \\
\hline
\end{tabular}




\subsubsection{Suitability of Rhenium as a Technetium Surrogate in Secondary Waste Form Leach Studies}

All the leach experiments (ANS 16.1, ASTM C1308, and EPA 1315) indicated that all three waste forms showed higher diffusivities for Re as compared to ${ }^{99} \mathrm{Tc}$. As an example, Re and ${ }^{99} \mathrm{Tc}$ diffusivities for Cast Stone, Ceramicrete and DuraLith measured from ANSI/ANS 16.1 leach tests are shown in Figure 5.27 - Figure 5.29.

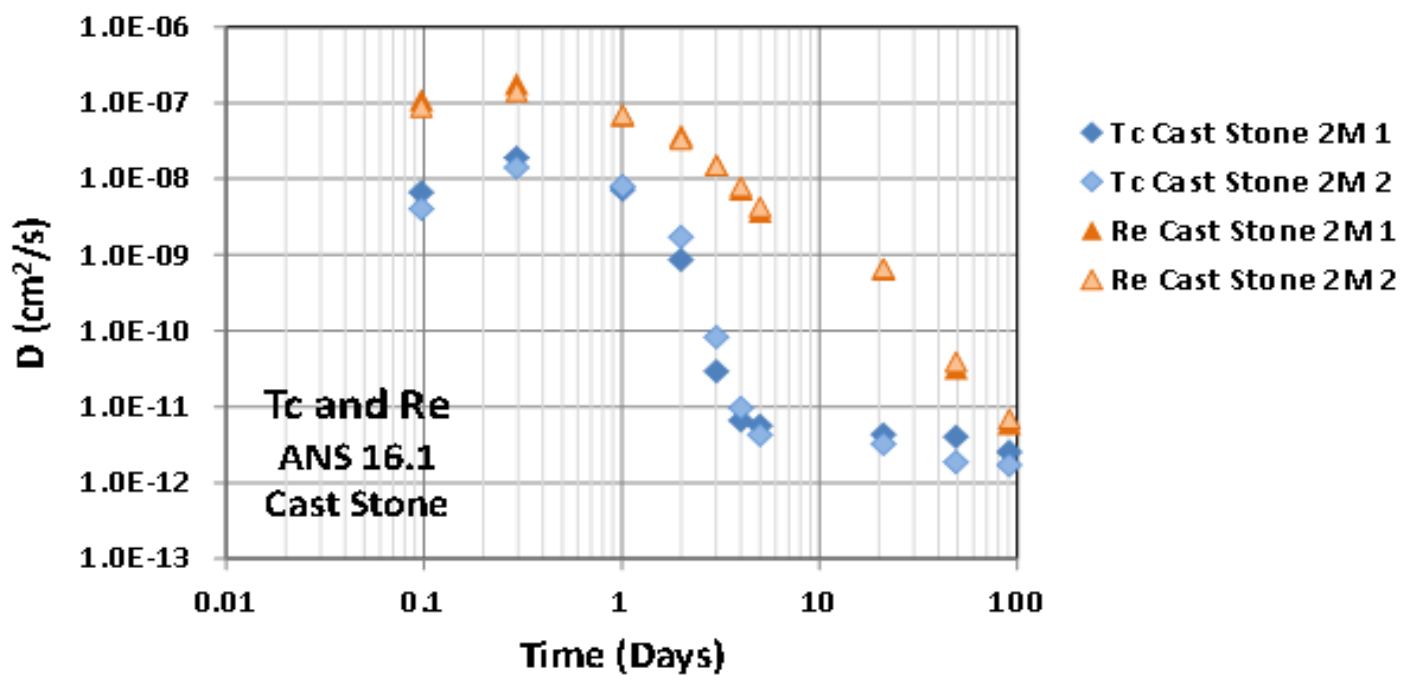

Figure 5.27. A Comparison of ${ }^{99} \mathrm{Tc}$ and Re Diffusivities for Cast Stone $2 \mathrm{M}$

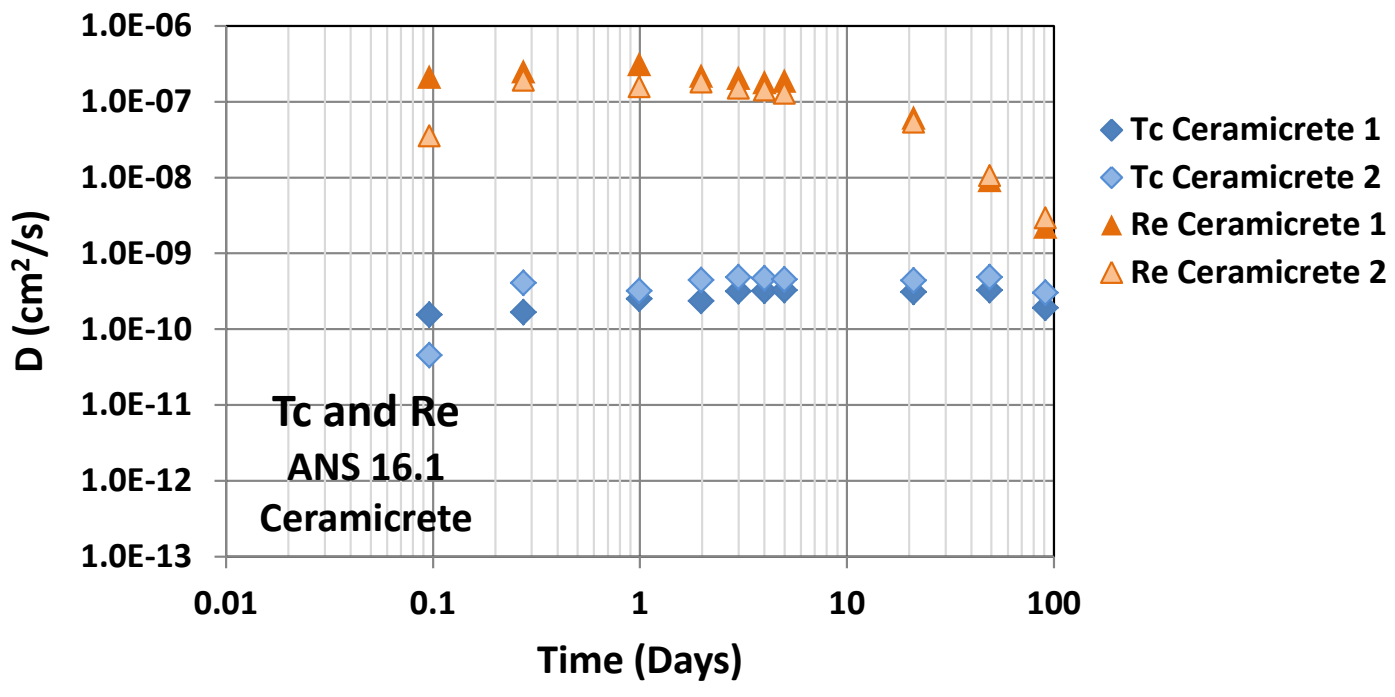

Figure 5.28. A Comparison of ${ }^{99} \mathrm{Tc}$ and Re Diffusivities for Ceramicrete 


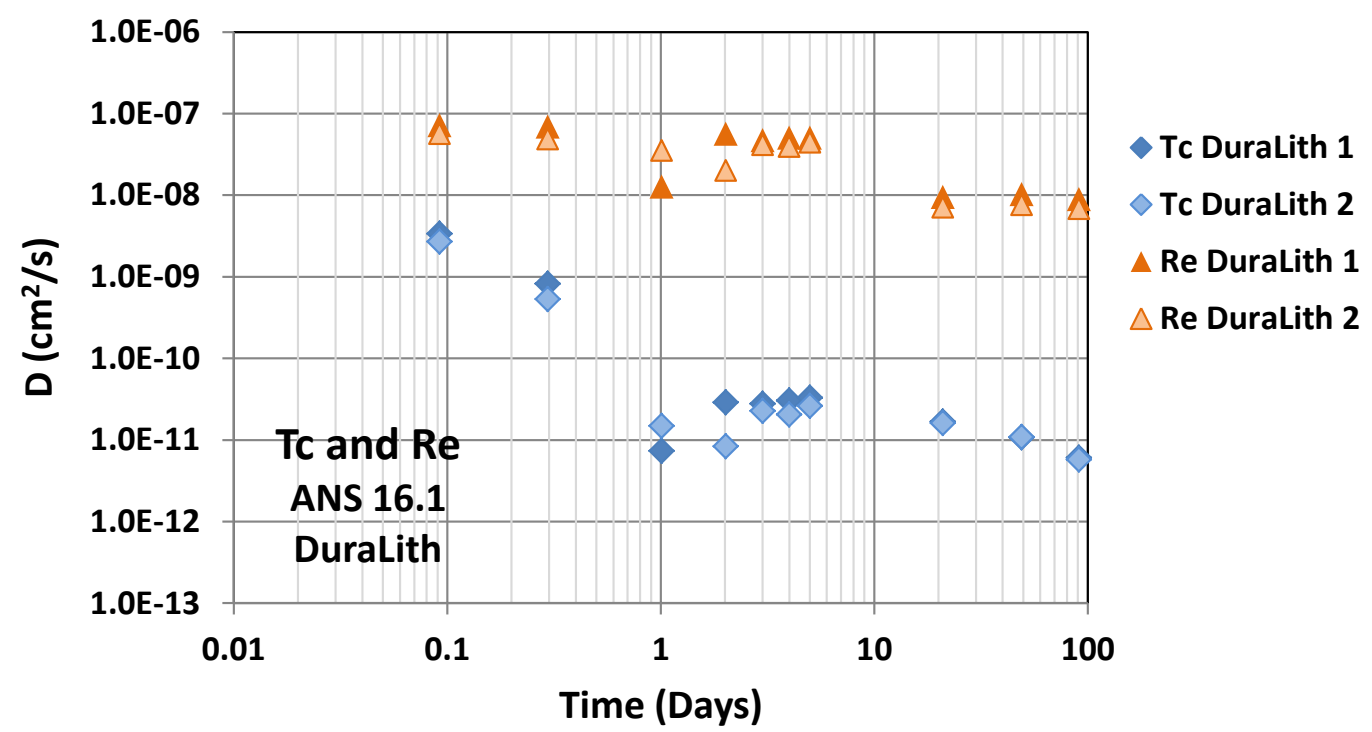

Figure 5.29. A Comparison of ${ }^{99} \mathrm{Tc}$ and Re Diffusivities for DuraLith

The data indicated that all waste forms at all sampling times showed one to three orders of magnitude higher diffusivities for Re as compared to ${ }^{99} \mathrm{Tc}$ diffusivities. Clearly, these data suggest that Re is not an appropriate surrogate for technetium in low temperature secondary waste stabilization studies.

Such large diffusivity discrepancies between Re and ${ }^{99} \mathrm{Tc}$ diffusivities can be best understood from the differences in reducibility of these species from highly mobile anionic $7^{+}$species to very low mobility $4^{+}$redox species.

A number of studies have demonstrated that BFS, when used as a part of cementitious waste forms, is known to attenuate Tc(VII) release through reduction of Tc(VII) to Tc(IV) (Gilliam et al 1988, 1990; Langton 1988a,b; Lukens, et al. 2005, Lockrem 2005, Aloy et al. 2007, Spence and Shi 2005, Cooke et al 2009). Typically, BFS has reductive capacities that range from 0.82 to $4.79 \mathrm{meq} / \mathrm{g}$ (Lukens, et al. 2005, Aloy et al. 2007, Gilliam et al. 1990) therefore, when incorporated into a waste form can effectively reduce Tc (VII) to Tc (IV), thus reducing its diffusivity.

Both Cast Stone and DuraLith contain BFS; therefore these waste forms possess sufficient capacity to reduce added ${ }^{99} \mathrm{Tc}$. Also, Ceramicrete and DuraLith contain Sn(II) halides as additives to reduce Tc(VII) to the less mobile Tc(IV) redox state. Because of the presence of BFS and $\mathrm{Sn}$ (II) halides forms, Tc initially added in the $7^{+}$oxidation state to these waste forms is likely to exist in low diffusivity $\mathrm{Tc}(\mathrm{IV})$ forms.

In contrast, studies have shown that $\operatorname{Re}(\mathrm{VII})$ cannot be reduced to the less mobile $\operatorname{Re}(\mathrm{IV})$ state by the common reductants such as metallic Fe, BFS and Sn(II) (Krupka et al. 2006, Maset et al. 2006).

Therefore, Re added to the waste forms in the $7^{+}$redox state is likely to remain in the same highly mobile redox state.

It is clear from the literature data and the diffusivity measurements from the current studies that using $\operatorname{Re}(\mathrm{VII})$ as a surrogate for ${ }^{99} \mathrm{Tc}(\mathrm{VII})$ in low temperature secondary waste forms containing reductants will provide overestimated diffusivity values for ${ }^{99} \mathrm{Tc}$. Therefore, it is not appropriate to use Re as a surrogate for ${ }^{99} \mathrm{Tc}$ in future low temperature waste form studies. 


\subsubsection{A Comparison of Leach Tests}

A comparison of diffusivity leach test methods (ANS 16.1, ASTM C1308, EPA 1315) is listed in Table 4.1 and descriptions of each method are provided in Sections 4.4.1-4.4.3. Overall, the methods are very similar except for minor differences such as specified sample size, diameter-to-height ratio, and leachant volume. There are also minor differences in leach intervals and the total test times. All methods recommend the use of DIW as the leachant. Additionally, the ASTM C1308 method also allows the use of synthetic or natural groundwater or chemical solutions of choice.

The diffusivity data for ${ }^{99} \mathrm{Tc}$ for Cast Stone $2 \mathrm{M}$, Ceramicrete and DuraLith were compared to observe any differences in results obtained from these three leach tests. Also, the diffusivity equation from ANSI/ANS 16.1 was used to process the leach data obtained from ASTM C1308 to check any differences in the diffusivity values as a result of the more frequent sampling and shorter total test time (11 days) used in the latter test.

The results of the comparison are shown in Figure 5.30 - Figure 5.32. The diffusivity of ${ }^{99} \mathrm{Tc}$ from Cast Stone, Ceramicrete, and DuraLith calculated from three different leach methods showed that both short-term ( $\leq 10$ days) and long-term intervallic leaching were similar in magnitude.

These graphs indicate that all three methods provide similar ${ }^{99} \mathrm{Tc}$ diffusivity data for both short-time transient diffusivity as well as long-term ( $\leq 90$ days) steady diffusivity from each of the tested waste forms. Therefore, any one of the three methods can be used to determine the contaminant diffusivities from a selected waste form.

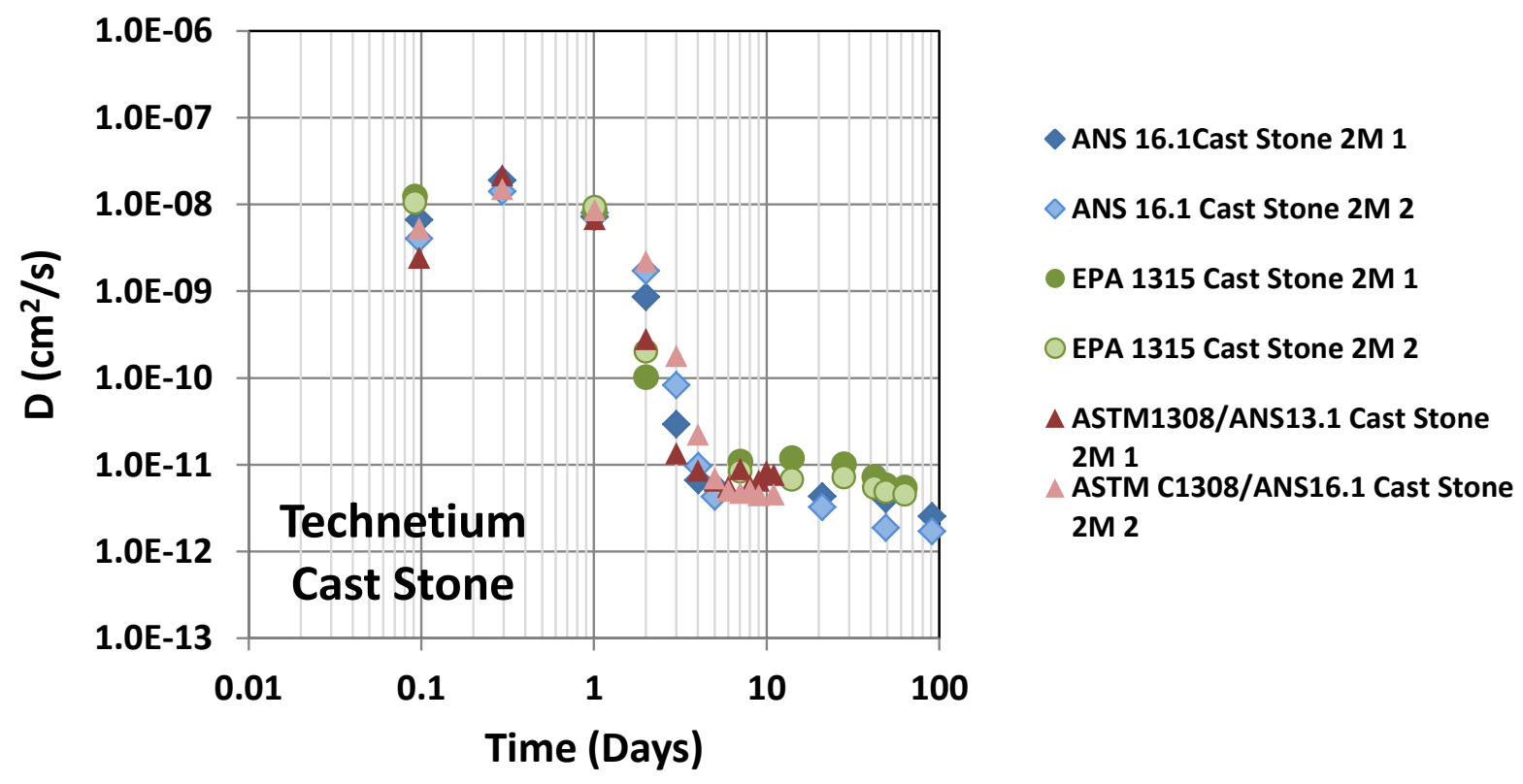

Figure 5.30. A Comparison of ${ }^{99} \mathrm{Tc}$ Diffusivity Values for Cast Stone Calculated from Data from Three Different Leach Methods 


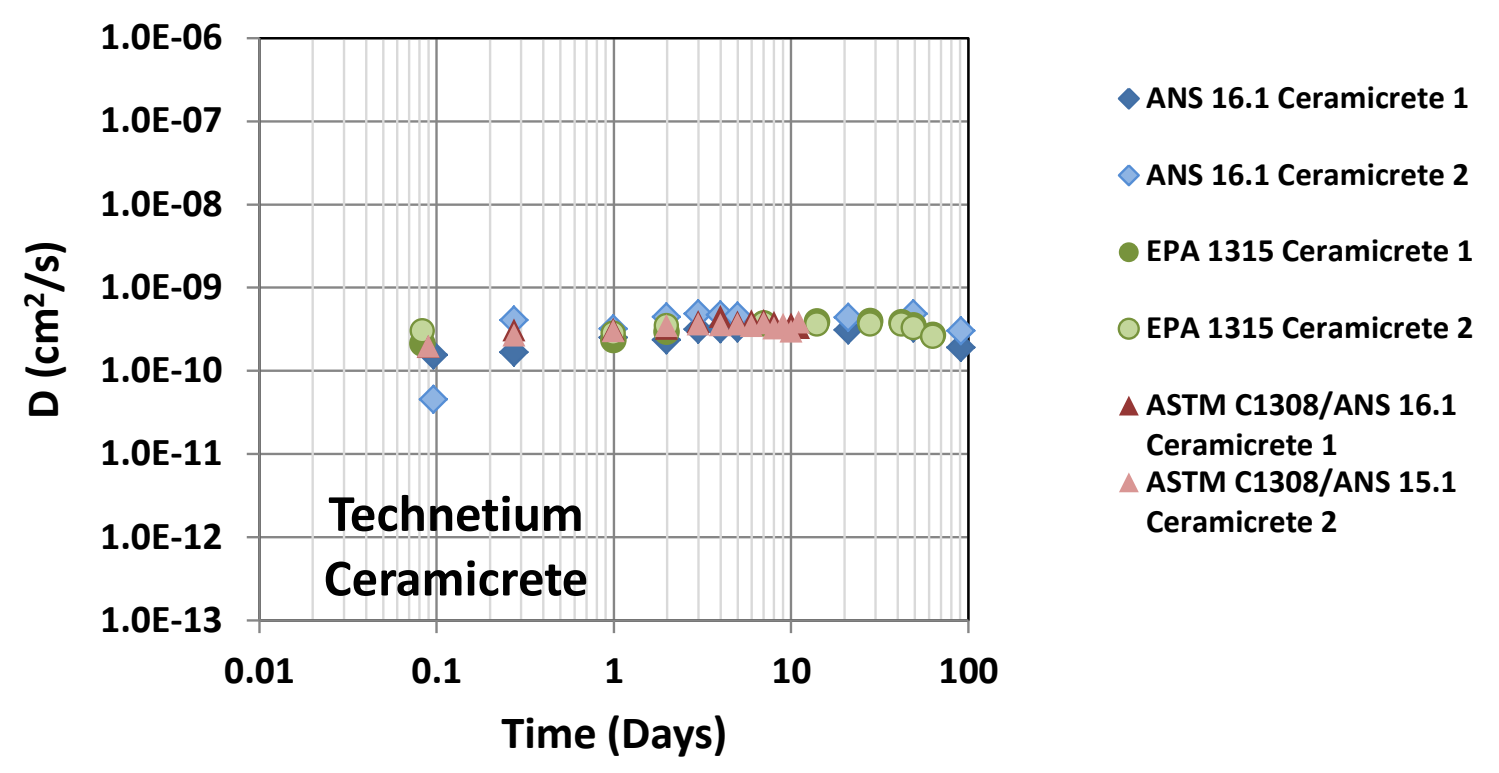

Figure 5.31. A Comparison of ${ }^{99} \mathrm{Tc}$ Diffusivity Values for Ceramicrete Calculated from Data from Three Different Leach Methods

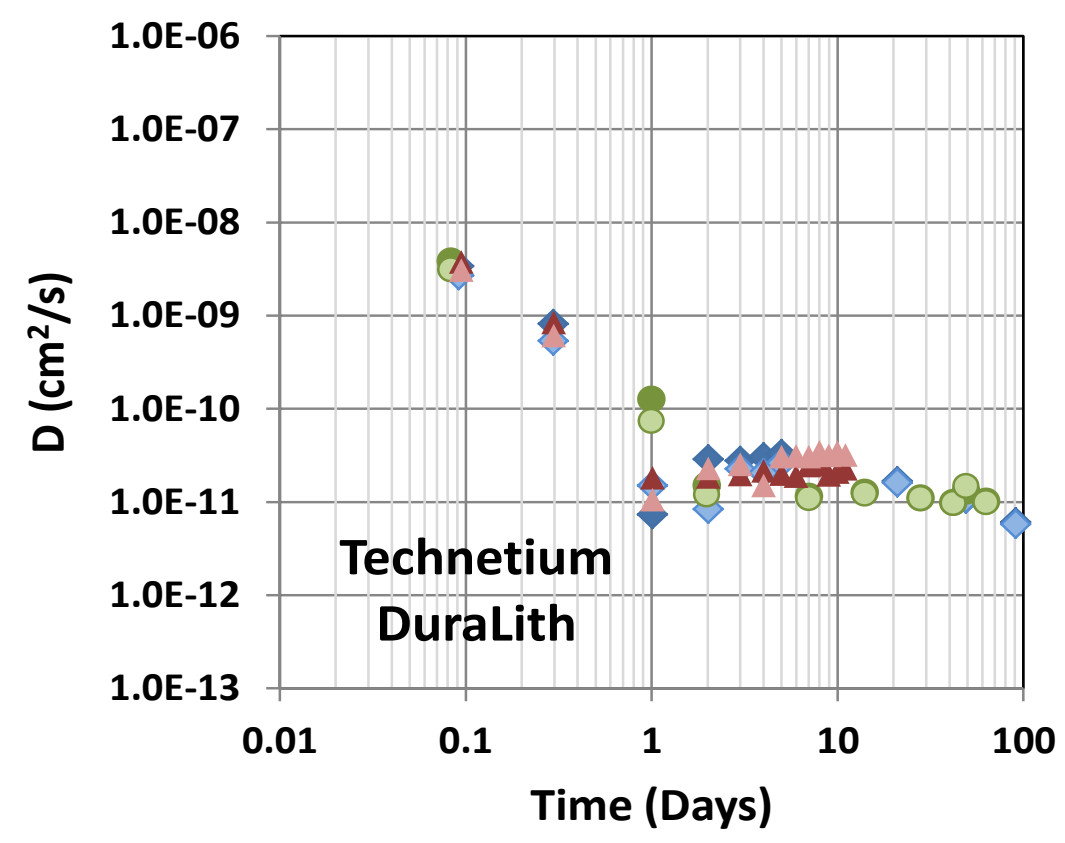

ANS 16.1 DuraLith 1

$\diamond$ ANS 16.1 DuraLith 2

EPA 1315 DuraLith 1

EPA 1315 DuraLith 2

$\triangle$ ASTM C1308/ANS 16.1

DuraLith 1

$\triangle$ ASTM C1308/ANS 16.1

DuraLith 2

Figure 5.32. A Comparison of ${ }^{99} \mathrm{Tc}$ Diffusivity Values for DuraLith Calculated from Data from Three Different Leach Methods 


\subsubsection{EPA 1313 Leach Test}

The results of the EPA 1313 leach test conducted on duplicate samples of Ceramicrete are listed in Table 5.15 and displayed graphically (Figure 5.33 - Figure 5.36). The data indicated that with decreasing $\mathrm{pH}$ the Ceramicrete released increasing concentrations of sodium and silica in to the leaching solution (Figure 5.33 and Figure 5.34).

Rhenium concentrations in leachates were constant throughout the tested $\mathrm{pH}$ range (Figure 5.35). In contrast, the concentrations of $\mathrm{Tc}$ were relatively constant in leachates from acidic to neutral $\mathrm{pH}$, and at higher $\mathrm{pH}$ values showed significant increases in concentrations (Figure 5.36). The natural $\mathrm{pH}$ of Ceramicrete was very alkaline ( $\mathrm{pH}$ : 11.2), and the concentrations of $\mathrm{Na}, \mathrm{Si}, \mathrm{Re}$ and $\mathrm{Tc}$ released at this $\mathrm{pH}$ fit the trend in release pattern observed over the range of $\mathrm{pH}$ values (Figure 5.33 - Figure 5.36).

Although both Re and Tc are Group 7B oxyanions, their leaching behavior indicates that in Ceramicrete, they have different sequestration and release mechanisms.

Table 5.15. Leachate Concentrations of Selected Elements and pH from EPA 1313 Test

\begin{tabular}{ccccc}
\hline $\begin{array}{c}\mathrm{pH} \\
(\mathrm{SU})\end{array}$ & $\begin{array}{c}\mathrm{Na} \\
(\mathrm{mg} / \mathrm{l})\end{array}$ & $\begin{array}{c}\mathrm{Si} \\
(\mathrm{mg} / \mathrm{L})\end{array}$ & $\begin{array}{c}\mathrm{Re} \\
(\mu \mathrm{g} / \mathrm{L})\end{array}$ & $\begin{array}{c}{ }^{99} \mathrm{Tc} \\
(\mu \mathrm{g} / \mathrm{L})\end{array}$ \\
\hline Sample 1 & & & & \\
\hline 12.6 & 799 & 38.6 & 95.2 & 36.70 \\
12.2 & 708 & 14.3 & 90.2 & 30.60 \\
8.87 & 784 & 7.44 & 85.1 & 5.62 \\
7.91 & 816 & 35.8 & 85.0 & 1.36 \\
7.20 & 1020 & 41.6 & 92.7 & 0.140 \\
4.22 & 1410 & 1330 & 82.1 & 0.199 \\
1.90 & 1460 & 2350 & 89.4 & 0.192 \\
\hline Sample 2 & & & & \\
\hline 12.6 & 804 & 46.5 & 92.0 & 37.60 \\
12.2 & 680 & 14.2 & 87.9 & 30.70 \\
8.90 & 790 & 6.18 & 88.4 & 6.17 \\
7.97 & 830 & 28.5 & 86.2 & 1.52 \\
7.41 & 1030 & 42.7 & 86.9 & 0.196 \\
4.16 & 1390 & 1480 & 85.1 & 0.419 \\
1.91 & 1490 & 2320 & 88.3 & 0.171 \\
\hline
\end{tabular}




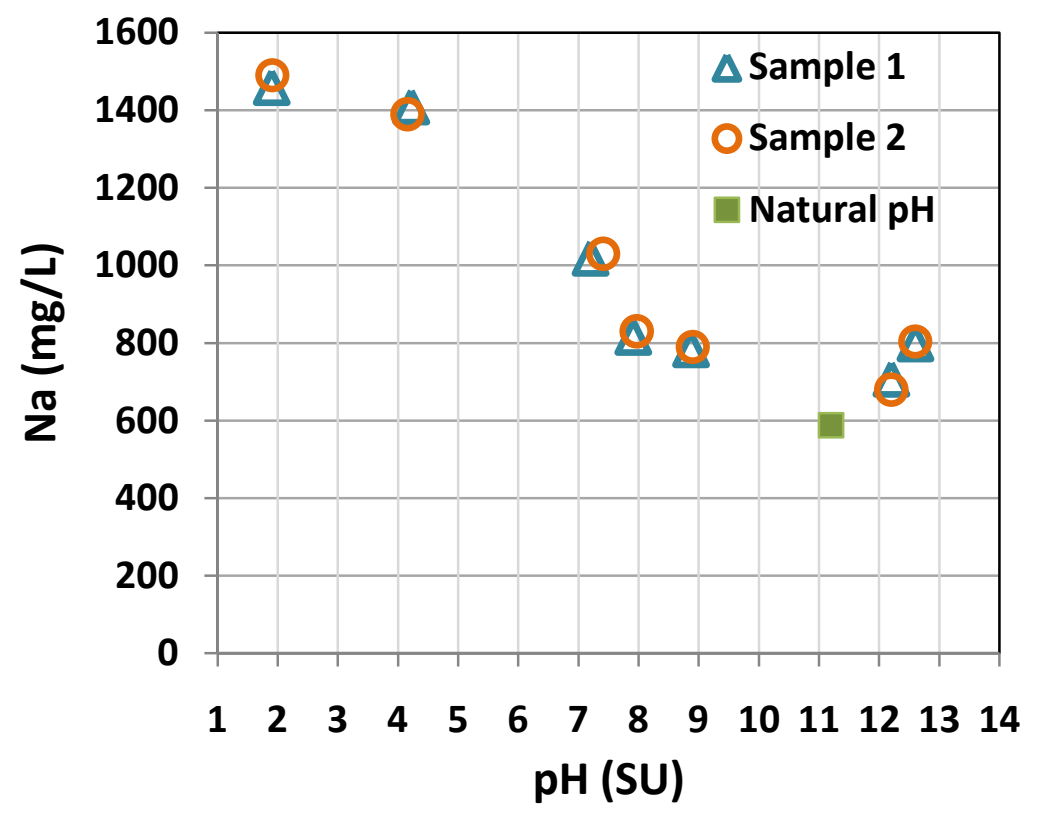

Figure 5.33. Sodium Concentrations in EPA 1313 Method Leachates from Ceramicrete

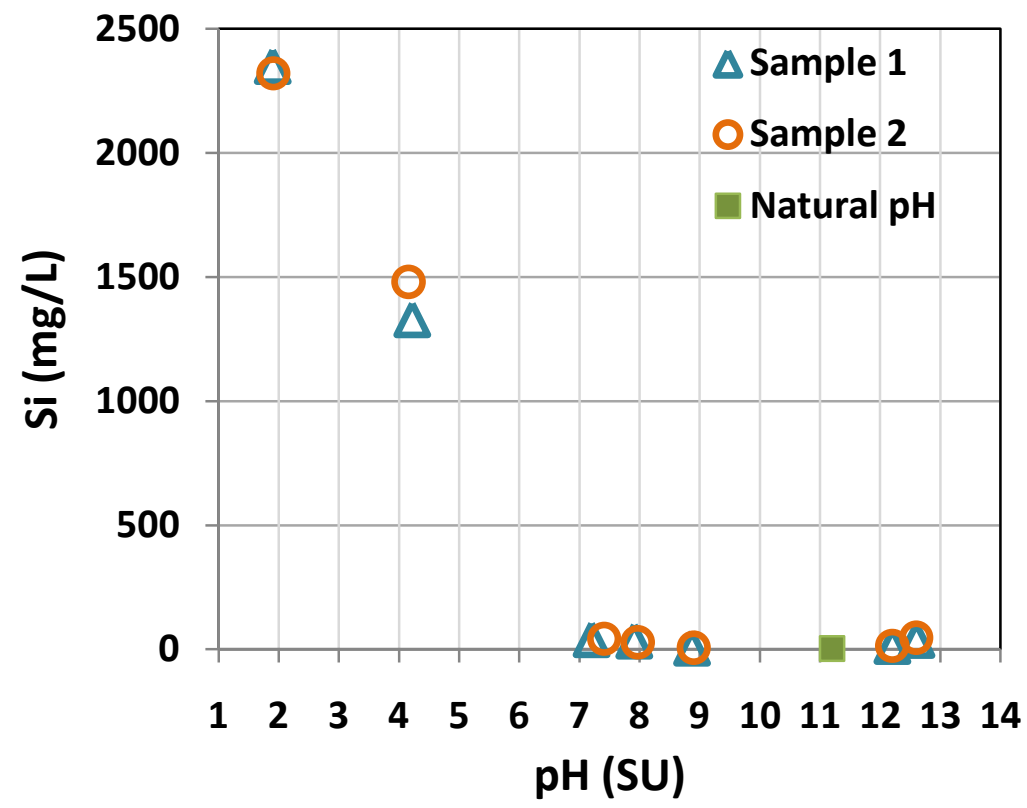

Figure 5.34. Silica Concentrations in EPA 1313 Method Leachates from Ceramicrete 


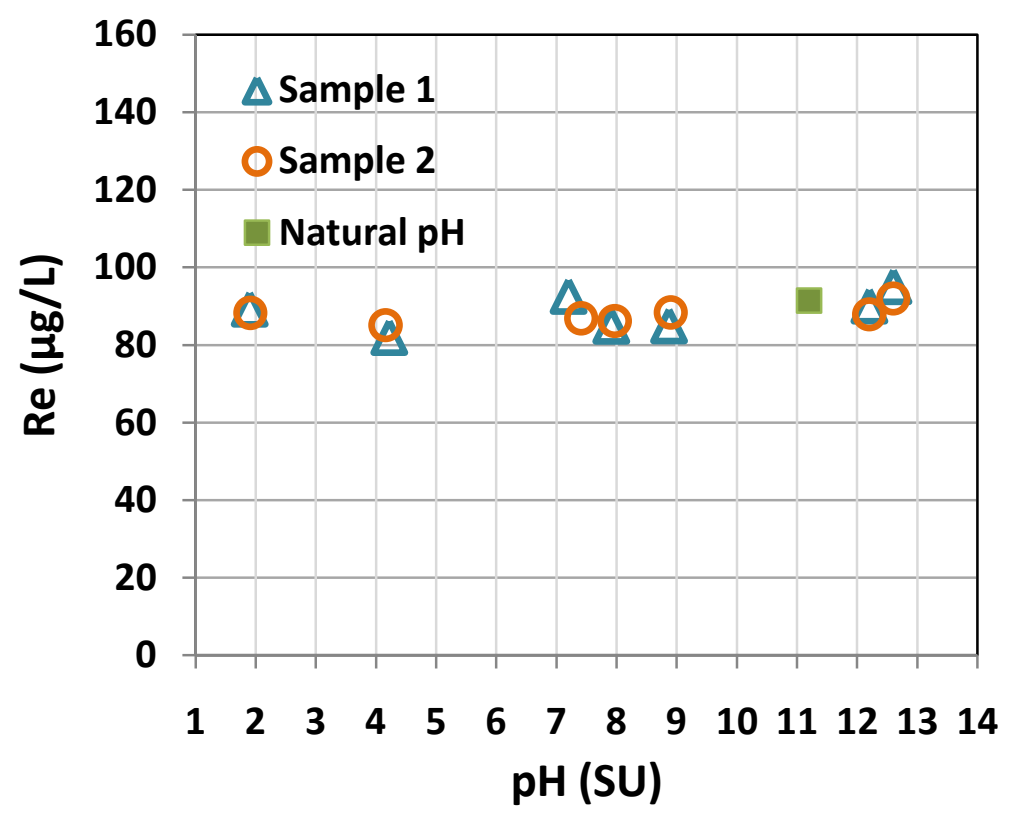

Figure 5.35. Rhenium Concentrations in EPA 1313 Method Leachates from Ceramicrete

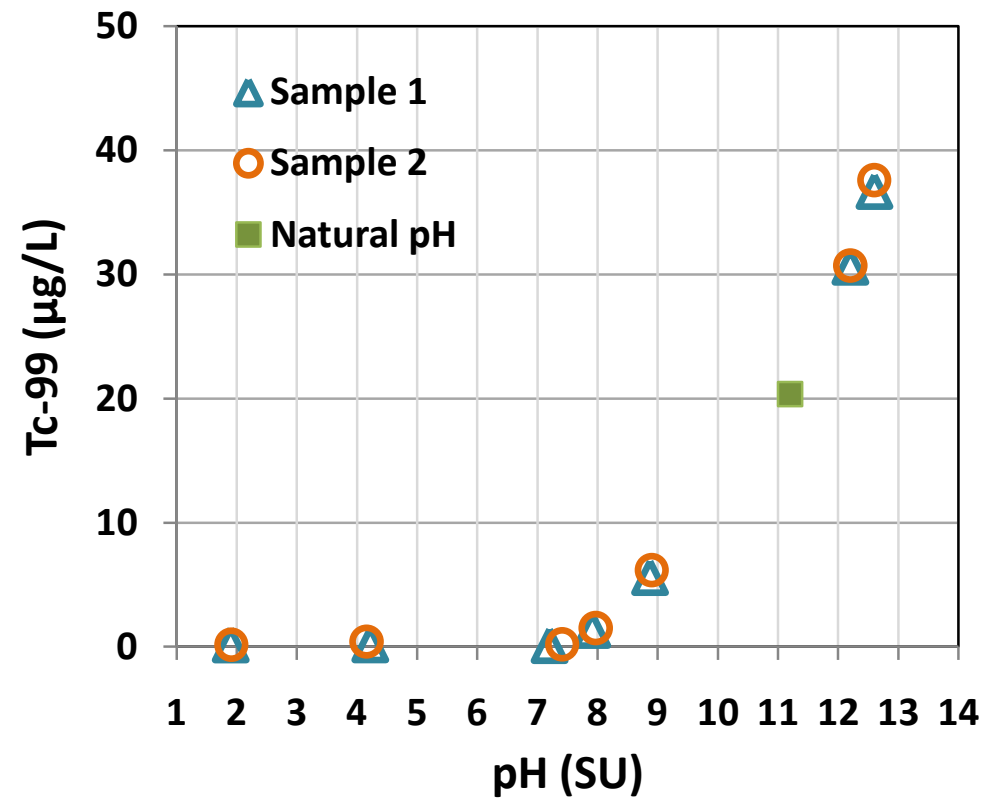

Figure 5.36. Technetium Concentrations in EPA 1313 Method Leachates from Ceramicrete

\subsubsection{EPA 1316 Leach Test}

The results of the EPA 1316 leach test conducted on duplicate samples of Ceramicrete are listed in Table 5.16 and displayed graphically in Figure 5.37 - Figure 5.40. The data indicated decreasing concentrations of selected constituents, namely Re, Tc and Na, with increasing liquid-to-solid (LS) ratios. The concentrations of I and Si in the leachates were below detection limits. 
Table 5.16. Leachate Concentrations of Selected Elements from EPA 1316 Test

\begin{tabular}{ccccccc}
\hline $\begin{array}{c}\text { LS Ratio } \\
(\mathrm{ml} / \mathrm{g} \text { dry })\end{array}$ & $\begin{array}{c}\mathrm{pH} \\
(\mathrm{SU})\end{array}$ & $\begin{array}{c}\mathrm{Na} \\
(\mathrm{mg} / \mathrm{L})\end{array}$ & $\begin{array}{c}\mathrm{Si} \\
(\mathrm{mg} / \mathrm{L})\end{array}$ & $\begin{array}{c}\mathrm{Re} \\
(\mu \mathrm{g} / \mathrm{L})\end{array}$ & $\begin{array}{c}{ }^{99} \mathrm{Tc} \\
(\mu \mathrm{g} / \mathrm{L})\end{array}$ & $\begin{array}{c}{ }^{127} \mathrm{I} \\
(\mathrm{mg} / \mathrm{L})\end{array}$ \\
\hline Sample 1 & & & & & & \\
10 & 10.5 & 623 & $<2.62$ & 87.6 & 14.8 & $<1.00$ \\
5 & 10.5 & 1150 & $<2.62$ & 184 & 30.1 & $<1.00$ \\
2 & 11.0 & 2200 & $<2.62$ & 488 & 94 & $<1.00$ \\
Sample 2 & & & & & & \\
10 & 10.5 & 624 & $<2.62$ & 88.2 & 15.3 & $<1.00$ \\
5 & 10.5 & 1160 & $<2.62$ & 187 & 29.6 & $<1.00$ \\
2 & 11.4 & 2020 & 3.47 & 494 & 108 & $<1.00$ \\
\hline
\end{tabular}

The concentrations of $\mathrm{Tc}, \mathrm{Re}$, and $\mathrm{Na}$ indicate that the solid-liquid equilibration at the lowest LS ratio reflects the pore solution composition of granular Ceramicrete material. The relationship between measured concentrations and the LS ratios for these constituents were curvilinear and appeared to be asymptotic at $\mathrm{LS}$ ratios $\geq 10$ as a consequence of pore water dilution effects.

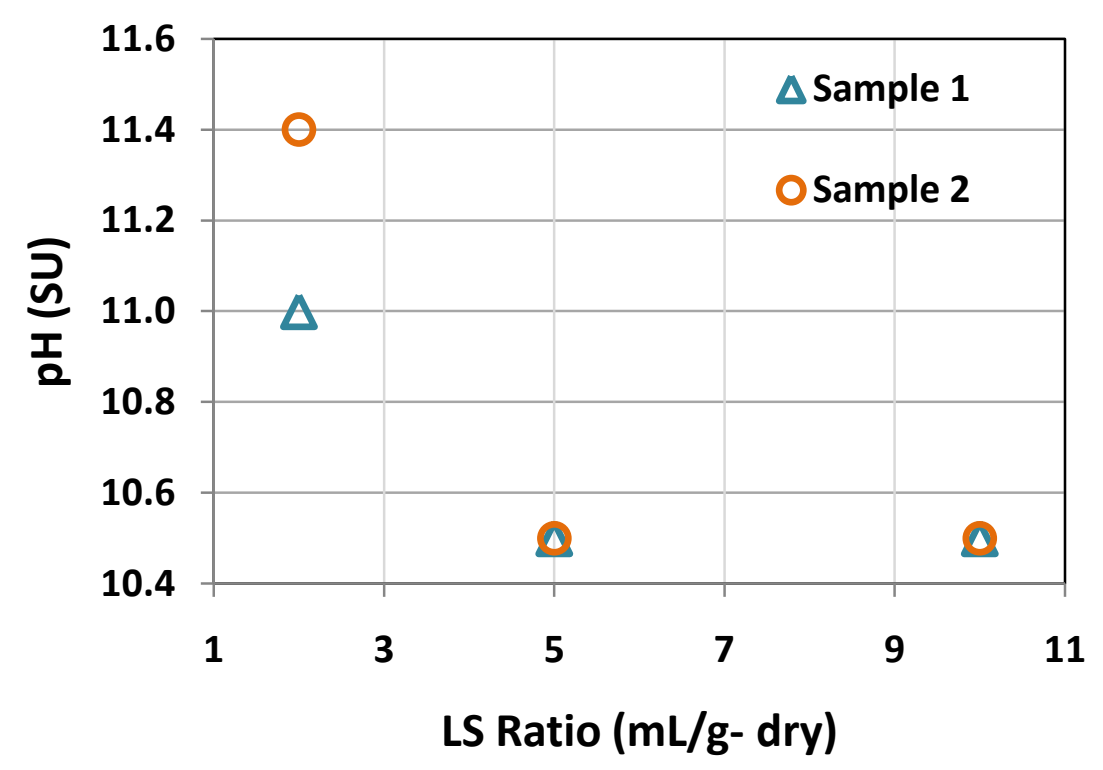

Figure 5.37. EPA 1316 Method Ceramicrete Leachate $\mathrm{pH}$ Values 


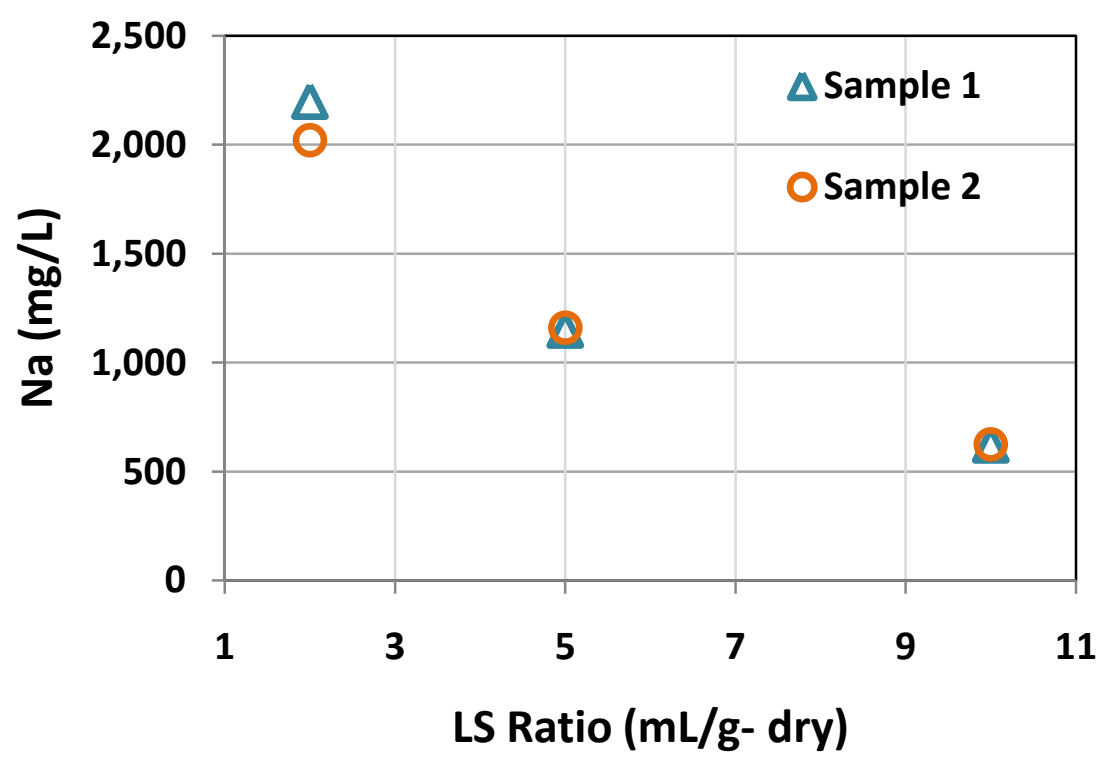

Figure 5.38. Sodium Concentrations in EPA 1316 Method Leachates from Ceramicrete

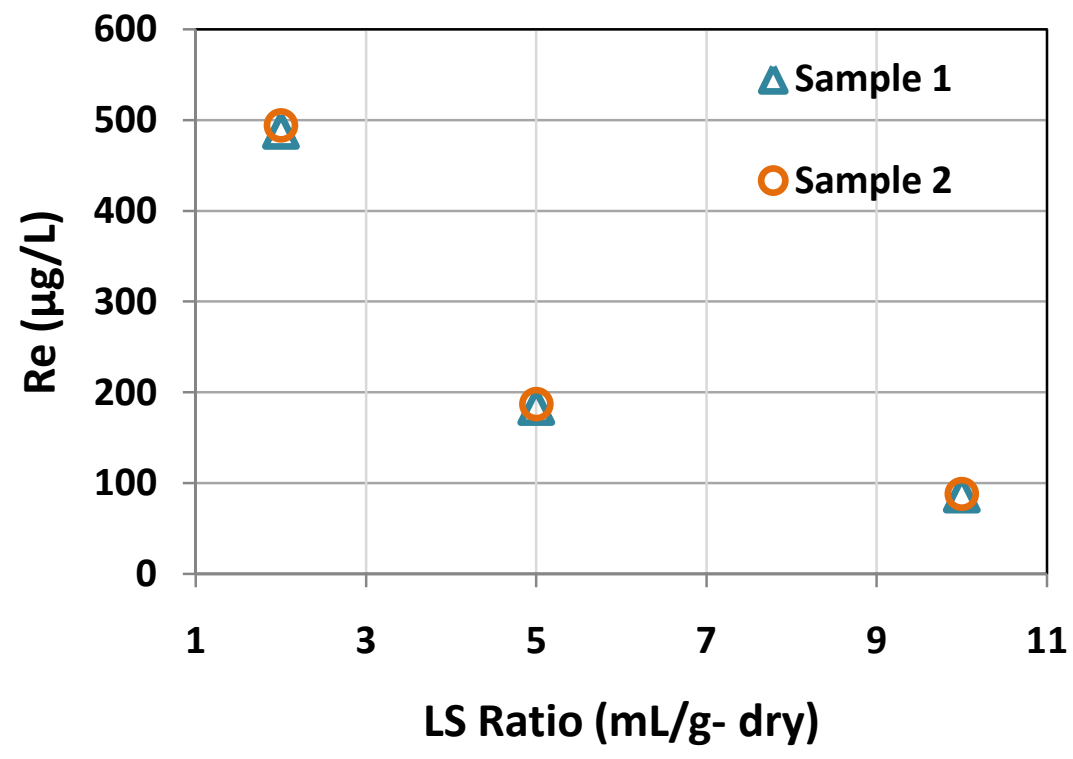

Figure 5.39. Rhenium Concentrations in EPA 1316 Method Leachates from Ceramicrete 


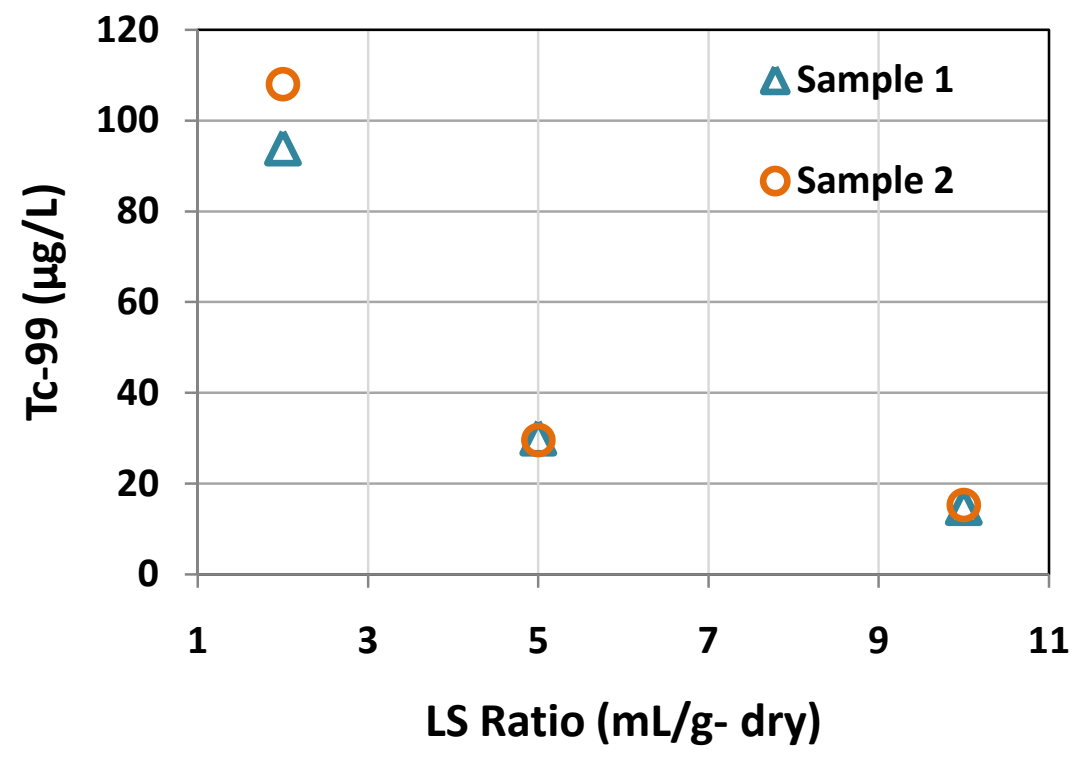

Figure 5.40. Technetium Concentrations in EPA 1316 Method Leachates from Ceramicrete

\subsubsection{Toxicity Characteristic Leaching Procedure (EPA 1311)}

The results of the TCLP tests on various waste form samples are listed in Table 5.17. The data indicated that the concentrations of both RCRA metals and the underlying hazardous constituents leached from all the waste forms were two to four orders of magnitude lower than the UTS limits. Therefore, all the waste forms passed the Land Disposal Requirements in 40 CFR Part 268 by meeting the Universal Treatment Standards in 40 CFR 268.48. 
Table 5.17. TCLP Test Results for Cast Stone, Ceramicrete and DuraLith Waste Forms

\begin{tabular}{|c|c|c|c|c|c|c|c|c|c|c|c|}
\hline \multirow{4}{*}{$\begin{array}{c}\text { Regulated } \\
\text { Constituent }\end{array}$} & \multicolumn{2}{|c|}{ Cast Stone $2 \mathrm{M}$} & \multicolumn{2}{|c|}{ Cast Stone 4M } & \multicolumn{2}{|c|}{ Cast Stone 6M } & \multicolumn{2}{|c|}{ Ceramicrete } & \multicolumn{2}{|c|}{ DuraLith } & \multirow[b]{2}{*}{$\mathrm{UTS}^{(\mathrm{a})}$} \\
\hline & $\begin{array}{c}\text { CS-11-S1- } \\
4-402-1\end{array}$ & $\begin{array}{c}\text { CS-11-S1- } \\
4-402-2\end{array}$ & $\begin{array}{c}\text { CS-11-S1- } \\
2-603-1\end{array}$ & $\begin{array}{c}\text { CS-11-S1- } \\
2-603-2\end{array}$ & $\begin{array}{c}\text { CS-11-S1- } \\
6-502-1\end{array}$ & $\begin{array}{c}\text { CS-11-S1- } \\
6-502-2\end{array}$ & $\begin{array}{c}\text { CE-11-S1- } \\
2-102-1\end{array}$ & $\begin{array}{c}\text { CE-11-S1- } \\
2-102-2\end{array}$ & $\begin{array}{c}\text { GP-11-S1- } \\
6-802-1\end{array}$ & $\begin{array}{c}\text { GP-11-S1- } \\
6-802-2\end{array}$ & \\
\hline & \multicolumn{11}{|c|}{ Concentration $(\mu \mathrm{g} / \mathrm{L})$} \\
\hline & \multicolumn{11}{|c|}{ RCRA Metals } \\
\hline Arsenic & $<40.00$ & $<40.00$ & $<40.00$ & $<40.00$ & $<40.00$ & $<40.00$ & $<40.00$ & $<40.00$ & $<40.00$ & $<40.00$ & 5,000 \\
\hline Barium & 187 & 170 & 243 & 251 & 144 & 154 & 3.17 & 3.59 & 352 & 325 & 21,000 \\
\hline Cadmium & $<0.93$ & $<0.93$ & $<0.93$ & $<0.93$ & $<0.93$ & $<0.93$ & $<0.93$ & $<0.93$ & $<0.93$ & $<0.93$ & 110 \\
\hline Chromium & $<1.37$ & 3.38 & 5.54 & 6.10 & 2.43 & 3.46 & 6.09 & 6.12 & 20.9 & 20.0 & 600 \\
\hline Lead & $<6.65$ & $<6.65$ & $<6.65$ & 8.11 & $<6.65$ & $<6.65$ & $<6.65$ & $<6.65$ & $<6.65$ & 7.65 & 750 \\
\hline Mercury & 0.0030 & 0.0033 & 0.0084 & 0.0107 & 0.0050 & 0.0078 & 0.0240 & 0.0549 & 1.4063 & 1.1971 & 25 \\
\hline Selenium & $<100$ & $<100$ & 115.2 & $<100$ & $<100$ & $<100$ & $<100$ & $<100$ & $<100$ & $<100$ & 5,700 \\
\hline \multirow[t]{2}{*}{ Silver } & $<1.35$ & $<1.35$ & $<1.35$ & $<1.35$ & $<1.35$ & $<1.35$ & 31.6 & 34.1 & 79.1 & 85.0 & 140 \\
\hline & \multicolumn{11}{|c|}{ Underlying Hazardous Constituents } \\
\hline Antimony & $<50.0$ & $<50.0$ & $<50.0$ & $<50.0$ & $<50.0$ & $<50.0$ & $<50.0$ & $<50.0$ & $<50.0$ & $<50.0$ & 1,150 \\
\hline Beryllium & 0.380 & 0.683 & 0.554 & $<0.31$ & 0.782 & 0.931 & 0.909 & 0.856 & 5.37 & 4.79 & 1,220 \\
\hline Nickel & $<1.90$ & 6.68 & 10.4 & 10.9 & 4.52 & 3.90 & 43.4 & 44.5 & 16.1 & 15.7 & 11,000 \\
\hline Thallium & $<25.0$ & $<25.0$ & $<25.0$ & $<25.0$ & $<25.0$ & $<25.0$ & $<25.0$ & $<25.0$ & $<25.0$ & $<25.0$ & 200 \\
\hline
\end{tabular}




\subsection{Conclusions}

Cast Stone, Ceramicrete, and DuraLith secondary waste formulations were tested to demonstrate whether these waste forms will meet requirements for disposal in the IDF. The current Phase II testing included characterizing the physical and chemical properties and to generate data for evaluating whether these waste forms intended for disposal in IDF meet requirements of DOE Order 435.1 and permit requirements established by Ecology.

In Phase II testing, the Cast Stone, Ceramicrete, and DuraLith waste forms were prepared based on the waste form development work conducted for these waste forms and the baseline secondary-waste simulant. A summary of the results of waste form preparation and characterization follows.

- Monoliths of Cast Stone, Ceramicrete and DuraLith were prepared using the appropriate dry ingredients and $\mathrm{S} 1$ baseline simulant. Using 2-M, 4-M, and 6-M Na simulants resulted in solid waste loadings of $3.4 \%, 7.8 \%$ and $13.5 \%$ for Cast Stone specimens. Using optimized formulations resulted in solid waste loadings of $2.3 \%$ and $8.6 \%$ by weight for Ceramicrete and DuraLith, respectively.

- The chemical composition of Cast Stone is dominated by Al, Ca, Si, O, and LOI (carbonate, oxalate etc) that account for $\sim 80 \%$ of the waste mass. In Ceramicrete the dominant components on the oxide basis are $\mathrm{K}, \mathrm{Mg}, \mathrm{P}, \mathrm{Ca}, \mathrm{Al}, \mathrm{H}$, and LOI ( $\sim 90 \%$ of waste mass). Ceramicrete had the highest water content $(\sim 16 \%)$, perhaps due to the presence of hydration water of the phosphate mineral. In DuraLith, on the oxide basis Si accounted for nearly $40 \%$ of the waste mass. Al, Ca, alkalis (K and $\mathrm{Na}$ ), LOI, and water comprised $\sim 50 \%$ of the mass of DuraLith.

- Depending on the Na molarity of the simulant, the Cast Stone monoliths contained ${ }^{99} \mathrm{Tc}$ concentrations that ranged from $1.06 \mu \mathrm{g} / \mathrm{g}$ (Cast Stone $2 \mathrm{M}$ ) to $3.34 \mu \mathrm{g} / \mathrm{g}$ (Cast Stone 6M). Rhenium concentrations in Cast Stone specimens ranged from $1.93 \mu \mathrm{g} / \mathrm{g}$ to $6.30 \mu \mathrm{g} / \mathrm{g}$ respectively. Ceramicrete contained the lowest concentrations of both the spikes $\left({ }^{99} \mathrm{Tc}: 0.67 \mu \mathrm{g} / \mathrm{g}\right.$, Re: $\left.1.34 \mu \mathrm{g} / \mathrm{g}\right)$. In DuraLith, the concentrations of ${ }^{99} \mathrm{Tc}$ and Re were found to be $2.09 \mu \mathrm{g} / \mathrm{g}$ and $3.28 \mu \mathrm{g} / \mathrm{g}$ respectively.

- X-ray diffraction analysis indicated that the cured waste form specimens consisted mainly of amorphous components. Ceramicrete contained about $26 \%$ crystalline phases consisting of K-struvite $(\sim 19 \%)$, periclase $(\sim 4.8 \%)$, and quartz $(\sim 2 \%)$. Crystalline components in Cast Stone specimens consisted of mainly calcite $(\sim 5.8-11 \%)$, hatrurite $(\sim 1.5-3.6 \%)$, and quartz $(\sim 1.6-2.5 \%)$. Additionally, Cast Stone specimens prepared with 2-M Na simulant contained about $3.7 \%$ ettringite. Principal crystalline phases in DuraLith specimens were quartz $(\sim 6.4 \%)$ and albite $(4.8 \%)$.

- SEM-EDS examination of the specimens indicated that the Cast Stone consisted of a relatively dense matrix with a network of fine cracks. EDS indicated that the Cast Stone matrix contained mainly Si, $\mathrm{Ca}, \mathrm{Na}, \mathrm{Al}$ and $\mathrm{Mg}$ with trace quantities of $\mathrm{Fe}, \mathrm{Mn}, \mathrm{Ti}, \mathrm{K}, \mathrm{S}$ and $\mathrm{Cl}$. Ceramicrete had a relatively porous matrix with wide interconnected cracks. The elemental composition of this waste form was dominated by $\mathrm{P}, \mathrm{K}, \mathrm{Mg}, \mathrm{Ca}$ and $\mathrm{Si}$. DuraLith exhibited a relatively dense matrix with an extensive network of fine to large cracks. The major elements in DuraLith were $\mathrm{Si}, \mathrm{Ca}, \mathrm{Al}, \mathrm{Na}$, and $\mathrm{K}$.

- Compressive strength tests conducted on specimens cured for 28 and 90 days, thermally cycled, and 90-day water immersed specimens indicated that all three waste forms exceeded the minimum compressive strength requirement of 3.45 MPa (500 psi) set by the IDF that is consistent with NRC's Waste form Technical Position. Two out of six 28-day cured Ceramicrete samples did not meet the minimum strength requirement of $3.45 \mathrm{MPa}$, indicating a failure rate of $\sim 33 \%$. 
- No free liquids were observed after the all the waste forms were cast or during the curing period.

- The results of the diffusivity leach tests were as follows:

- Technetium diffusivity: ANSI/ANS 16.1, ASTM C1308, and EPA 1315 tests indicated that all the waste forms had leachability indices better than the target LI $>9$ for technetium.

- Rhenium diffusivity: Cast Stone 2M specimens, when tested using EPA 1315 protocol, had leachability indices better than the target LI $>9$ for technetium based on rhenium as a surrogate for technetium. All other waste forms tested by the ANSI/ANS 16.1, ASTM C1308, and EPA 1315 test methods had leachability indices that were below the target LI $>9$ for Tc based on rhenium release.

Literature data and the diffusivity measurements from the current studies, indicate that using $\operatorname{Re}(\mathrm{VII})$ as a surrogate for ${ }^{99} \mathrm{Tc}(\mathrm{VII})$ in low temperature secondary waste forms containing reductants will provide overestimated diffusivity values for ${ }^{99} \mathrm{Tc}$. Therefore, it is not appropriate to use $\mathrm{Re}$ as a surrogate for ${ }^{99} \mathrm{Tc}$ in future low temperature waste form studies.

- Iodine diffusivity: ANSI/ANS 16.1, ASTM C1308, and EPA 1315 tests indicated that the three waste forms had leachability indices that were below the target LI > 11 for iodine.

- Sodium diffusivity: All the waste form specimens tested by the three leach methods (ANSI/ANS 16.1, ASTM C1308, and EPA 1315) exceeded the target LI value of 6.

- Comparison of Diffusivities from three leach methods: All three leach methods (ANSI/ANS 16.1, ASTM C1308 and EPA 1315) provided similar ${ }^{99}$ Tc diffusivity values for both short-time transient diffusivity effects as well as long-term ( $\leq 90$ days) steady diffusivity from each of the three tested waste forms (Cast Stone 2M, Ceramicrete and DuraLith). Therefore, any one of the three methods can be used to determine the contaminant diffusivities from a selected waste form.

- EPA 1313 test on Ceramicrete specimens showed that the natural $\mathrm{pH}$ of this waste form is very alkaline $(\mathrm{pH}=11.2)$. Relatively constant release of rhenium was observed from Ceramicrete throughout the resultant $\mathrm{pH}$ range of the leachates, whereas technetium at higher leachate $\mathrm{pH}$ showed significant increases in concentrations. Although both Re and Tc are Group 7B oxyanions, their leaching behavior indicates that in Ceramicrete these two elements have different sequestration and release mechanisms.

- The results of the EPA 1316 leach test conducted on Ceramicrete indicated decreasing concentrations of selected constituents, namely $\mathrm{Re}, \mathrm{Tc}$ and $\mathrm{Na}$, with increasing liquid-to-solid ratios. The concentrations of total I and Si in the leachates were below detection limits.

- In the TCLP tests, the concentrations of both the RCRA metals and the underlying hazardous constituents leached from all the waste forms were two to four orders of magnitude lower than the UTS limits. Therefore, all the waste forms passed the Land Disposal Requirements in 40 CFR Part 268 by meeting the Universal Treatment Standards in 40 CFR 268.48. 


\subsection{References}

40 CFR Part 268. 2010. Land Disposal Restrictions." Code of Federal Regulations, U.S. Environmental Protection Agency, Washington, DC.

Aloy, A, EN Kovarskaya,, JR Harbour, CA Langton and EW Holtzscheiter., 2007. "Pretreatment of TcContaining Waste and its Effect on Tc-99 Leaching from Grouts." Materials Research Society Symposium Proceedings 985, p. 367-372. Materials Research Society, Warrendale, PA.

ANSI/ANS-American National Standards Institute/American Nuclear Society. 2003. Measurement of the Leachability of Solidified Low-Level Radioactive Wastes by a Short Term Test Procedure.

ANSI/ANS-16.1, La Grange Park, Illinois.

ANSI/ANS-American National Standards Institute/American Nuclear Society. 1992. Solid Radioactive Waste Processing System for Light-Water-Cooled Reactor Plants. ANSI/ANS-55.1, La Grange Park, Illinois.

ASTM-American Society for Testing and Materials. 2010. Standard Test Method for Compressive Strength of Cylindrical Concrete Specimens. ASTM C39/C39M, West Conshohocken, Pennsylvania.

ASTM-American Society for Testing and Materials. 2008. Standard Test Method for Accelerated Leach Test for Diffusive Releases from Solidified Waste and a Computer Program to Model Diffusive,

Fractional Leaching from Cylindrical Waste Forms. ASTM C 1308, West Conshohocken, Pennsylvania.

ASTM-American Society for Testing and Materials. 1985. Standard Test Method for Thermocycling of Electroplated Plastics. ASTM B553, West Conshohocken, Pennsylvania.

Cooke GA, JB Duncan, MD Guthrie, and LL Lockrem. 2009. Assessment of Pertechnetate Getters, Reductants, and Stabilization. DOE Technical Exchange, Denver, Colorado.

Crank J. 1986. Mathematics of Diffusion. $2^{\text {nd }}$ ed. p. 424, Oxford University Press, London.

DOE_U.S. Department of Energy. 1999. Order 435.1. Radioactive Waste Management.

DOE-U.S. Department of Energy. 2011. Justification of Mission Need for the Secondary Liquid Waste Treatment Project. U.S. Department of Energy, Office of River Protection, Richland, Washington.

Ecology - Washington State Department of Ecology, U.S. Environmental Protection Agency and U.S. Department of Energy (Ecology, EPA, and DOE). 1989. Hanford Facility Agreement and Consent Order, As Amended. Olympia, Washington.

EPA-U.S. Environmental Protection Agency. 1999. Toxicity Characteristics Leaching Procedure. Test Methods for Evaluating Solid Wastes - Physical and Chemical Methods SW-846. Method 1311.

Ebert WL. 2010. Radionuclide Release from Slag and Concrete Waste Materials Part 1: Conceptual Models of Leaching from Complex Materials and Laboratory Test Methods. NUREG/CR-7025, U.S. Nuclear Regulatory Commission, Washington D.C. 
EPA-U.S. Environmental Protection Agency. 2009a. Draft Method 1313 - Leaching Test (Liquid-Solid Partitioning as a Function of Extract pH) of Constituents in Solid Materials Using Parallel Batch Extractions. Pre-Release Draft for Comment, October 2009.

EPA-U.S. Environmental Protection Agency. 2009b. Draft Method 1315 - Mass Transfer Rates of Constituents in Monoliths or Compacted Granular Materials Using a Semi-dynamic Tank Leaching Test. Pre-Release Draft for Comment, October 2009.

EPA-U.S. Environmental Protection Agency. 2009c. Draft Method 1316 - Leaching Test (Liquid-Solid Partitioning as a Function of Liquid-to-Solid Ratio) of Constituents in Solid Materials Using a Parallel Batch Extraction Test. Pre-Release Draft for Comment, October 2009.

EPA-U.S. Environmental Protection Agency. 2008. Methods for Evaluating Solid Waste, Physical/Chemical Methods. SW-846, U. S. Environmental Protection Agency, Washington, D.C.

EPA-U.S. Environmental Protection Agency. 2004. Paint Filters Liquids Test-Physical and Chemical Methods SW-846. Method 9095B, Rev, 2.

Gong W, W Lutze, M Chaudhuri, H Gan, GA Diener, and IL Pegg. 2006. DuraLith Low Temperature Waste Forms VSL-05R5150-1, Rev. 1, Limited Distribution Report, Vitreous State Laboratory, The Catholic University of America, Washington, D.C.

Gilliam TM, RD Spence, B Evans-Brown, IL Morgan, WD Bostick and JL Shoemaker. 1988.

Performance Testing of Blast Furnace Slag for Immobilization of Technetium in Grout. CONF-880903-17. Oak Ridge National Laboratory, Oak Ridge, TN.

Gilliam TM, Spence RD, Bostick WD, and Shoemaker, JL. 1990. "Solidification/Stabilization of Technetium in Cement-based Grouts." J. Haz. Mater. 24, 189-197.

Gong W, W Lutze, and IL Pegg. 2011. Test Plan: DuraLith Alkali-Aluminosilicate Geopolymer Waste Form Testing for Hanford Secondary Waste. VSL-10T2140-1, Vitreous State Laboratory, The Catholic University of America, Washington, D.C.

Josephson GB, GF Piepel, and JH Westsik, Jr. 2010. Selection of Secondary Waste Test Compositions. Pacific Northwest National Laboratory, Richland, Washington. (Limited distribution).

Krupka KM, CF Brown, HT Schaef, SM Heald, MM Valenta, and BW Arey. 2006. "Rhenium uptake as Analogue for ${ }^{99} \mathrm{Tc}$ by Steel Corrosion Products." In Proceedings of the $11^{\text {th }}$ International High-Level Radioactive Waste Management Conference (IHLRWM), B Sagar, Ed. American Nuclear Society, Las Vegas, Nevada.

Langton CA. 1988a. Challenging Applications for Hydrated and Chemically Reacted Ceramics. DP-MS88-163. Savannah River Laboratory, Aiken, SC.

Langton CA. 1988b. "Slag-based Saltstone Formulations.” Materials Research Society Symposium Proceedings 112, 61-70. 
Lockrem LL, 2005. Hanford Containerized Cast Stone Facility Task 1 - Process Testing and Development, Final Test Report. RPP-RPT-26742, Rev 0, Fluor Hanford, Richland, WA.

Lukens WW, JJ Bucher, DK Shuh, and NM Edelstein. 2005. "Evolution of Technetium Speciation in Reducing Grout." Environmental Science and Technology 39, 8064-8070.

Maset, ER, SH Sidhu, AW Fisher, A Wheydon, PJ Worsfold, AJ Cartwright and MK Roach. 2006. "Effect of Organic Co-Contaminants on Technetium and Rhenium Speciation and Solubility under Reducing Conditions" Environmental Science and Technology 40:5472-5477.

Mattigod SV, JH Westsik Jr, and NJ Fix. 2011. Secondary Waste Form Testing Project: Phase II Test Plan: Task 5 Waste Acceptance Testing. Draft 57925-P2-T5-Rev 0, January 2011.

NRC-U.S. Nuclear Regulatory Commission. 2001. Research Needs for High-Level Waste Stored in Tanks and Bins at U.S. Department of Energy Sites. National Academy Press, Washington, D.C.

NRC-U. S. Nuclear Regulatory Commission. 1991. Waste Form Technical Position, Revision 1. U.S. Nuclear Regulatory Commission, Washington, D.C.

Office of River Protection (ORP). 2010. River Protection Project System Plan. ORP-11242 Revision 5, U.S. Department of Energy, Office of River Protection, Richland, Washington.

Pierce EM, SV Mattigod, RJ Serne, JP Icenhower, RD Scheele, W Um, N Qafoku and JH Westsik, Jr. 2010a. Review of Potential Candidate Stabilization Technologies for Liquid and Solid Secondary Waste Streams. PNNL-19122, Pacific Northwest National Laboratory, Richland, Washington

Pierce EM, W Um, KJ Cantrell, MM Valenta, JH Westsik, Jr, RJ Serne, and KE Parker. 2010b. Secondary Waste Form Screening Test Results - Cast Stone and Alkali Alumino-Silicate Geopolymer. PNNL-19505, Pacific Northwest National Laboratory, Richland, Washington.

RPP—River Protection Program. 2005. Integrated Disposal Facility Waste Acceptance Criteria, RPP8402, Rev 1, River Protection Program, U.S. Department of Energy, Richland, Washington.

Russell RL, MJ Schweiger, JH Westsik Jr, PR Hrma, DE Smith, AB Gallegos, MR Telancer, and SG Pitman. 2006. Low Temperature Waste Immobilization Testing. PNNL-16052. Pacific Northwest National Laboratory, Richland, Washington.

Singh D, VR Mandalika, S Parulekar, and AS Wagh. 2006. "Magnesium Potassium Phosphate Ceramic for ${ }^{99}$ Tc Immobilization.” Journal of Nuclear Materials 348:272-282.

Singh D. 2011. E-mail message. "FW: Ceramicrete make up for Large-scale demonstration" from D. Singh, (Argonne National Laboratory), to G Josephson and JH Westsik (Pacific Northwest National Laboratory), January 7, 2011, 10:35 a.m.

Spence RD and C Shi 2005. Stabilization and Solidification of Radioactive and Mixed Waste. CRC Press. p. 381. 
Sundaram SK, J Chun, W Um, KE Parker, CW Chung, JH Westsik Jr, MM Valenta, ML Kimura, SG Pitman, and CA Burns. 2011. Secondary Waste Form Development and Optimization-Cast Stone. PNNL-20159, Pacific Northwest National Laboratory, Richland, Washington. [Unpublished]

THOR $^{\circledR}$ 2009. Report for Treating Hanford LAW and WTP SW Simulants: Pilot Plant Mineralizing Flowsheet. RT-21-002 Revision 1, THOR Treatment Technologies, LLC, Denver, Colorado.

Wagh AS, D Singh, and S-Y Jeong. 1997. "Chemically Bonded Phosphate Ceramics for Low-Level Mixed-Waste Stabilization.” Journal of Environmental Science A32(2):527-541.

Wagh AS, S-Y Jeong, and D Singh. 1999. "High Strength of Phosphate Cements Using Industrial Byproduct Ashes." published in Proceedings of the First Engineering Foundation Conference on High Strength Concrete. Kona, Hawaii. p. 542-553. 


\section{Distribution}

No. of

Copies

OFFSITE

3 The Catholic University of America Washington DC 20064

W Gong

W Lutze

I L Pegg

1 D Singh

Argonne National Laboratory

9700 South Case Avenue

Argonne, IL 60439
No. of

$\underline{\text { Copies }}$

ONSITE

4 Washington River Protection Solutions

MA Melvin

E6-30

DJ Swanberg

B1-55

KE Smith

E6-30

LE Thompson

E6-20

14 Pacific Northwest National Laboratory

PR Bredt

CW Chung

K9-09

GB Josephson

K6-24

MJ Lindberg

K9-69

SV Mattigod (5)

P7-54

KE Parker

K3-62

LM Peurrung

K3-62

RJ Serne

K9-09

W Um

K6-81

JH Westsik, Jr

P7-54

K7-15 



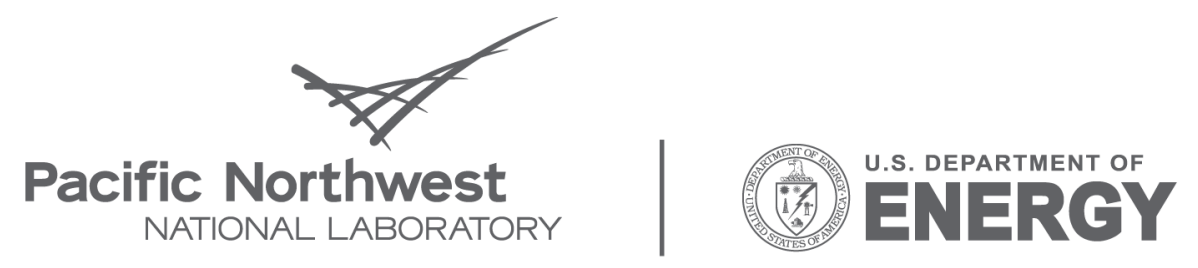

Proudly Operated by Battelle Since 1965

902 Battelle Boulevard

P.O. Box 999

Richland, WA 99352

1-888-375-PNNL (7665)

www.pnl.gov 